TESE DE DOUTORADO

DIREITO CIVIL

\title{
O ADIMPLEMENTO SUBSTANCIAL NA EXECUÇÃO DO CONTRATO
}

FACULDADE DE DIREITO

UNIVERSIDADE DE SÃO PAULO

Carlos Augusto de Carvalho Filho

SÃO PAULO-SP

2019 


\section{O ADIMPLEMENTO SUBSTANCIAL NA EXECUÇÃO DO CONTRATO}

Tese de doutorado apresentada à Banca Examinadora do Programa de Pós-Graduação em Direito, da Faculdade de Direito da Universidade de São Paulo (USP), como exigência parcial para a obtenção do título de Doutor em Direito, na área de concentração de Direito Civil.

Orientadora: Profa. Dra. Daisy Gogliano.

UNIVERSIDADE DE SÃO PAULO

FACULDADE DE DIREITO

SÃO PAULO-SP

2019 


\section{TESE DE DOUTORADO}

Carvalho Filho, Carlos Augusto de.

Título: O adimplemento substancial na execução do contrato. Autor: Carlos Augusto de Carvalho Filho - São Paulo, FADUSP, 2019, pp. 453.

Orientadora: Profa. Dra. Daisy Gogliano.

Tese de doutorado na área de Direito, subárea: Direito Civil. 


\section{CARLOS AUGUSTO DE CARVALHO FILHO}

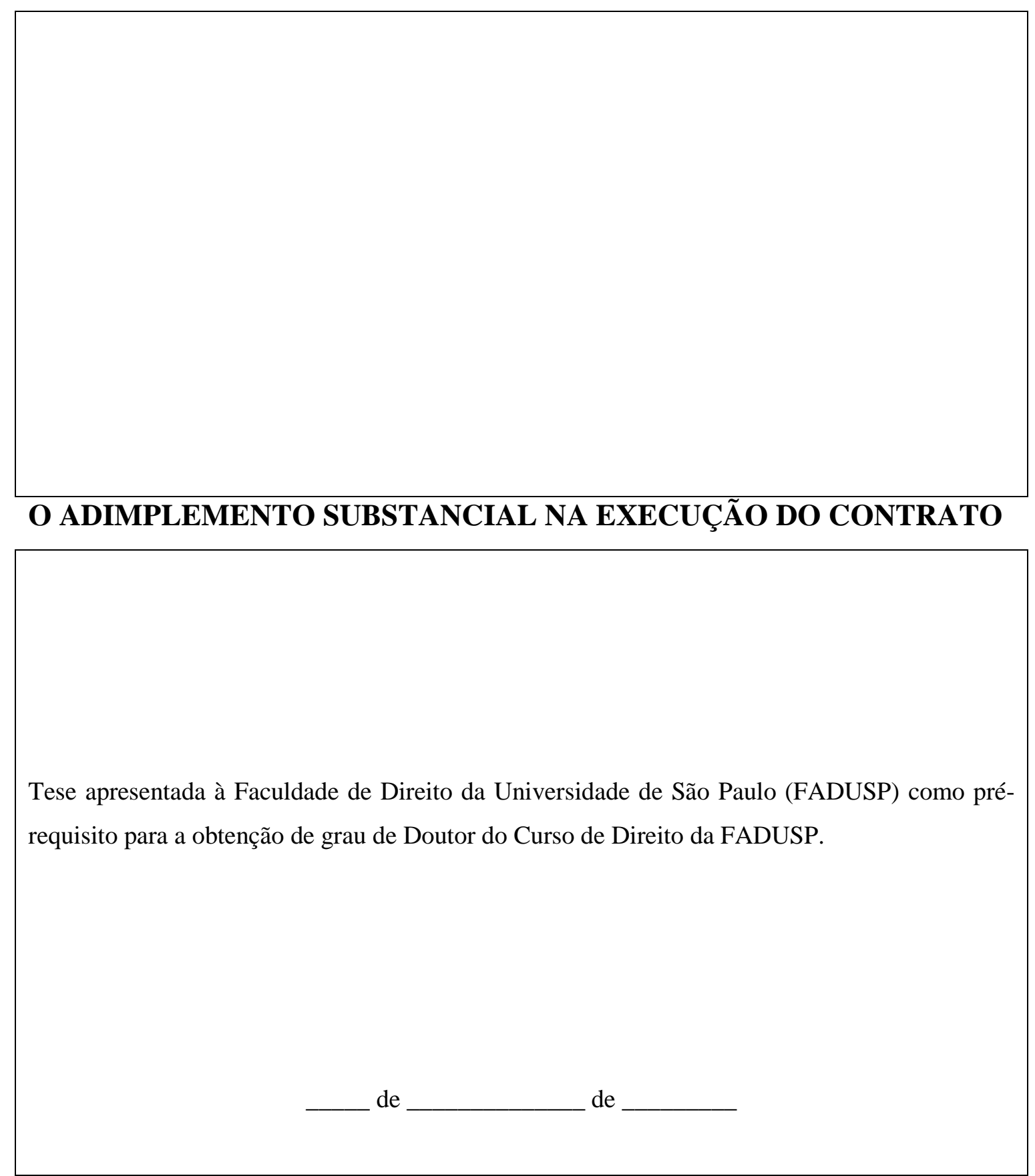




\section{BANCA EXAMINADORA}

Prof. Dr.

Universidade

Assinatura:

Profa. Dra.

Universidade

Assinatura:

Prof. Dr.

Universidade

Assinatura:

Prof. Dr.

Universidade

Assinatura:

Prof. Dr.

Universidade

Assinatura: 


\section{DEDICATÓRIA}

A meus filhos Carlos, Caio e Cássio,

que um dia compreenderão que se pode ir mais longe quando agitarem sua fé e realizarem a obra. 
AGRADECIMENTOS

A todos que de alguma forma contribuíram para este trabalho.

À orientadora, pelo estímulo, pela lucidez e pelos ensinamentos.

À minha mulher Clarice, pelo carinho e apoio de sempre. 


\section{EPÍGRAFE}

"Aquele, porém, que demonstra gosto por todo saber e se dedica com alegria ao estudo sem jamais se enjoar, poderíamos considerá-lo com justiça um filósofo."

(Sócrates, em A República de Platão)

"O temor do Senhor é o princípio do conhecimento; os loucos desprezam a sabedoria e a instrução."

(Provérbios de Salomão) 


\section{RESUMO}

CARVALHO FILHO, Carlos Augusto de. O adimplemento substancial na execução do contrato, pp. 453, grau de doutorado, Faculdade de Direito da Universidade de São Paulo, São Paulo, 2019.

O presente trabalho analisa o adimplemento substancial na execução dos contratos. O objetivo principal é definir e examinar quais são os principais fatores que estão envolvidos no surgimento da figura jurídica e nos seus efeitos. Após uma inserção histórica da figura no sistema romanístico, apresentou-se a origem da figura equivalente, a chamada substantial performance, no Direito Anglo-Americano, investigando-se suas características no sistema do Common Law. Em seguida, foi apresentada a atualidade dessa figura no Direito Brasileiro. Com efeito, o tema do adimplemento substancial insere-se no tópico da extinção das obrigações e aplica-se em grande parte aos contratos. O tema compreende alguns pontos: o conceito de obrigação como um processo, o papel do princípio da boa-fé objetiva no campo contratual, a funcionalização do direito de crédito e o interesse do devedor e a influência da figura do abuso do direito, além da teoria da causa, como função econômico-social do contrato. Enfocando a figura do adimplemento substancial no campo dos contratos, foram apontadas sua incidência e seus efeitos. $\mathrm{O}$ princípio da boa-fé objetiva tem forte influência no adimplemento substancial, uma vez que por esse princípio os contratos são cumpridos ainda que imperfeitamente. Numa perspectiva original da tese, foram apresentados os elementos para identificação do adimplemento substancial, a saber, a substancialidade da prestação efetivamente executada; a satisfação do interesse do credor, apesar da prestação imperfeita; diligência do devedor no cumprimento da prestação, ou seja, inexistência de culpa do devedor ao executar o contrato; proporcionalidade na aferição do quanto cumprido pelo devedor; e insignificância ou escassa importância do que o devedor deixou de prestar. Num outro passo, foram apresentadas questões acerca do adimplemento substancial: o adimplemento substancial e a segurança jurídica; o adimplemento substancial e a vedação ao enriquecimento sem causa; por fim, o adimplemento substancial e o abuso de direito. Deve-se ressaltar a figura do abuso de direito aplicada aos casos de direitos de crédito. De fato, em determinadas relações jurídicas, uma das partes exerce um direito, de forma que excede manifestamente os limites impostos pelo negócio jurídico, conforme o seu fim econômico ou social, pela boa-fé objetiva ou pelos bons costumes. Entre essas questões a respeito deste tema, indagou-se se o adimplemento substancial atende às exigências do cumprimento obrigacional, sem que haja enriquecimento injusto da parte cumpridora dos deveres contratuais e sem abuso no exercício desse direito. Além disso, mostrou-se qual o alcance dessa figura jurídica, quanto às etapas não somente de formação e execução do contrato, bem como de sua evidente extinção geradora de responsabilidade contratual ou não, concluindo que o adimplemento substancial extingue o contrato, embora se admita que parte de escassa importância possa ser executada posteriormente. Por fim, mostrou-se como se dá a aplicação da teoria do adimplemento substancial no Direito Brasileiro. Em suma, foi realizada uma análise investigativa do adimplemento substancial aplicada ao contrato, principalmente no âmbito civil, mostrando seus fundamentos jurídicos, fixando-se conceitos e demonstrando sua aplicabilidade na atualidade.

Palavras-chave: adimplemento substancial, resolução, contrato, obrigação, boa-fé. 


\section{ABSTRACT}

CARVALHO FILHO, Carlos Augusto de. Substantial performance in the execution of the contract, pp. 453, PhD, Faculty of Law, University of São Paulo, São Paulo, 2019.

This paper analyzes the substantial performance, called in Brazil "adimplemento substancial", in the execution of the contracts. The main objective is to define and examine which are the main factors that are involved in the emergence of the legal figure and its effects. After a historical insertion of the figure in the Roman system, the equivalent figure, the so-called "substantial performance", was presented in Anglo-American Law, investigating its characteristics in the Common Law system. Also, it was presented the actuality of this figure in Brazilian Law. In effect, the issue of substantial compliance lies in the topic of termination of obligations and applies in large part to contracts. The theme comprises a number of points: the concept of obligation as a process, the role of the principle of objective good faith in the contractual field, the functionalization of credit law and the interest of the debtor and the influence of the figure of abuse of the right, in addition to theory of cause, as an economic-social function of the contract. Focusing on the figure of substantial performance in the field of contracts, were pointed out its incidence and its effects. The principle of objective good faith has a strong influence on substantial compliance, since by this principle the contracts are fulfilled even if imperfectly. From an original perspective of the thesis, the elements for the identification of substantial compliance were presented, namely, the substantiality of the performance actually performed; satisfaction of the creditor's interest, despite the imperfect performance; diligence of the debtor in the performance of the performance, ie, no fault of the debtor in executing the contract; proportionality in measuring the amount paid by the debtor; and insignificance or little importance than the debtor failed to provide. In another step, questions were raised about substantive compliance: substantive compliance and legal certainty; substantial performance and prohibition of unjust enrichment; and finally, the substantial increase and abuse of rights. It should be noted that abuse of rights applies to cases of credit rights. In fact, in certain legal relations, one of the parties exercises a right, so that it clearly exceeds the limits imposed by the legal business, according to its economic or social purpose, objective good faith or good customs. Among these questions on this subject, it was inquired whether substantial compliance meets the requirements of mandatory compliance, without unjust enrichment of the party fulfilling the contractual obligations and without abuse in the exercise of this right. In addition, it was shown the scope of this legal figure, regarding the stages not only of formation and execution of the contract, as well as of its evident extinction generating contractual responsibility or not, concluding that the substantial compliance extinguishes the contract, although it is admitted which may be of little importance. Finally, it was shown how the application of the theory of substantial performance in the Brazilian Law takes place. In sum, an investigative analysis was carried out on the substantive compliance applied to the contract, mainly in the civil sphere, showing its legal bases, establishing concepts and demonstrating their applicability in the present time.

Keywords: substantial performance, dissolution, contracts, obligation, good faith. 


\section{RIASSUNTO}

CARVAlho Filho, Carlos Augusto de. Prestazioni sostanziali nell'esecuzione del contratto, pp. 453, dottorato, Facoltà di Giurisprudenza, Università di São Paulo, São Paulo, 2019.

Questo studio analizza l'importanza dell'inadempimento, la causa delle prestazione applicato ai contratti, cio é, le prestazioni sostanziali nell'esecuzione dei contratti. L'obiettivo principale è definire ed esaminare quali sono i principali fattori coinvolti nell'emergere della figura legale e dei suoi effetti. Dopo un inserimento storico della figura nel sistema romano, la figura equivalente, la cosiddetta "substantial performance", è stata presentata nella legge anglo-americana, indagando le sue caratteristiche nel sistema di Common Law. Successivamente, è stata presentata l'attualità di questa figura nella legge brasiliana. In effetti, la questione della conformità sostanziale sta nel tema della risoluzione degli obblighi e si applica in gran parte ai contratti. Il tema comprende una serie di punti: il concetto di obbligo come processo, il ruolo del principio di buona fede oggettiva nel campo contrattuale, la funzionalizzazione della legge sul credito e l'interesse del debitore e l'influenza della figura di abuso del diritto, teoria della causa, come funzione economico-sociale del contratto. Concentrandosi sulla figura di sostanziale adimplemento nel campo dei contratti, sono stati indicati la sua incidenza e i suoi effetti. Il principio di buona fede oggettiva ha una forte influenza sulla conformità sostanziale, poiché con questo principio i contratti sono soddisfatti anche se imperfettamente. Da una prospettiva originale della tesi, sono stati presentati gli elementi per l'identificazione della conformità sostanziale, vale a dire la sostanzialità delle prestazioni effettivamente eseguite; soddisfazione dell'interesse del creditore, nonostante l'imperfetta esecuzione; diligenza del debitore nell'esecuzione della prestazione, cioè, nessuna colpa del debitore nell'esecuzione del contratto; proporzionalità nel misurare l'importo pagato dal debitore; e irrilevanza o poca importanza che il debitore non ha fornito. In un altro momento, sono state sollevate domande sulla conformità sostanziale (substantial performance): conformità sostanziale e certezza del diritto; conformità sostanziale e divieto di arricchimento senza causa; e infine, l'aumento sostanziale e l'abuso dei diritti. Va notato che l'abuso dei diritti si applica ai casi di diritti di credito. Infatti, in alcuni rapporti giuridici, una delle parti esercita un diritto, in modo che superi chiaramente i limiti imposti dall'attività legale, in base al suo scopo economico o sociale, alla buona fede oggettiva o alle buone abitudini. Tra queste domande su questo argomento, è stato chiesto se una sostanziale conformità soddisfa i requisiti di conformità obbligatoria, senza arricchimento senza causa della parte che adempie agli obblighi contrattuali e senza abuso nell'esercizio di questo diritto. Inoltre, è stato illustrato lo scopo di questa figura legale, per quanto riguarda le fasi non solo di formazione ed esecuzione del contratto, nonché della sua evidente estinzione generando o meno la responsabilità contrattuale, concludendo che la sostanziale conformità (substantial performance) estingue il contratto, sebbene sia ammesso che può essere di poca importanza. Infine, è stato mostrato come si svolge l'applicazione della teoria del sostanziale adempimento (substantial performance) nella legge brasiliana. In sintesi, è stata condotta un'analisi investigativa sulla conformità sostanziale applicata al contratto, principalmente in ambito civile, mostrando le sue basi giuridiche, stabilendo concetti e dimostrandone l'applicabilità nel tempo presente.

Parole chiave: inadempimento di scarsa importanza, risoluzione, contratto, l'obbliglo, buona fede. 


\section{LISTA DE ABREVIATURAS}

Ac. - Acórdão

AgRg - Agravo Regimental

ADC - Anuario de Derecho Civil

AI - Agravo de Instrumento

AIDD - Agravo de Instrumento contra Decisão Denegatória

Ap. Civ. - Apelação Cível

BGB - Bürgerliches Gesetzbuch

BMJ - Boletim do Ministério da Justiça

CC - Código Civil

CDC - Código de Defesa do Consumidor

CEDAM - Casa Editrice Dott. Antonio Milani

$\mathrm{CF}$ - Constituição Federal

cit. - citado anteriormente

CPC - Código de Processo Civil

DJe - Diário de Justiça eletrônico

Des. - Desembargador

ed. - edição

EmbDecl - Embargos de Declaração

EI - Embargos Infringentes

EDCBP - Estudos de Direito Civil Brasileiro e Português

FDPUCSP - Faculdade de Direito da Pontifícia Universidade Católica de São Paulo

FADUSP ou FDUSP - Faculdade de Direito da Universidade de São Paulo

fl. - folha

HUP - Harvard University Press

j. - julgado

LGDJ - Librairie Générale de Droit et de Jurisprudence

loc. cit. - lugar citado

op. cit. - obra citada

OUP - Oxford University Press 
p. - página

pp. - páginas

RAL - Restatement of America Law

RDC - Revista de Direito do Consumidor

RDC it. - Rivista di Diritto Civile

RDCC - Revista de Direito Civil Contemporâneo

RDCom - Rivista del Diritto Commerciale

RDP - Revista de Derecho Privado

RE - Recurso Extraordinário

RFDRS - Revista da Faculdade de Direito do Rio Grande do Sul

RFDUSP - Revista da Faculdade de Direito da Universidade de São Paulo

RGZ - Reichsgericht in Zivilsachen

Rel. - Relator

REsp - Recurso Especial

RIDC - Revue Internationale de Droit Comparé

RLJ - Revista de Legislação e Jurisprudência

RT - Revista dos Tribunais

RTDC - Revista Trimestral de Direito Civil

RTDC fr. - Revue Trimestrielle de Droit Civil

RTDPC - Rivista Trimestrale di Diritto e Procedura Civile

s.d. - sem data

ss. - seguintes

STF - Supremo Tribunal Federal

STJ - Superior Tribunal de Justiça

TDCCom - Trattato di Diritto Civile e Commerciale

TJDFT - Tribunal de Justiça do Distrito Federal e Territórios

TJMG - Tribunal de Justiça de Minas Gerais

TJMT - Tribunal de Justiça de Mato Grosso

TJRJ - Tribunal de Justiça do Rio de Janeiro

TJRS - Tribunal de Justiça do Rio Grande do Sul

TJSC - Tribunal de Justiça de Santa Catarina

TJSP - Tribunal de Justiça do Estado de São Paulo

UCC - Uniform Commercial Code (Código de Comércio Uniforme) 
v. - volume

YLJ - Yale Law Journal 


\section{SUMÁRIO}

Introdução.

1. O adimplemento substancial e o Direito Romano.

2. Histórico da substantial performance.

2.1. A origem histórica da substantial performance.

2.2. O sistema jurídico do Common Law.

2.2.1. Os precedentes e a equity.

2.2.2. Particularidades do Direito nos Estados Unidos da América.

2.2.3. Common Law versus Civil Law.

2.2.4. O contrato e seus elementos (do séc. XVIII até o séc. XX).

2.2.5. Os efeitos do contrato no sistema do Common Law.

2.2.6. Conceito de consideration.

2.3. Conceito de causa no Direito de origem romana e a consideration.

2.4. A substantial performance como execução do negócio.

3. O adimplemento substancial no Direito Comparado.

3.1. Sistema romano-germânico-canônico.

3.1.1. Itália.

3.1.2. Portugal.

3.1.3. França.

3.1.4. Alemanha.

3.1.5. Espanha.

3.1.6. Argentina.

3.1.7. A Convenção de Viena e outras normas.

3.2. Sistema do Common Law.

3.2.1. Inglaterra.

3.2.2. Estados Unidos da América. 
4. O adimplemento substancial no Direito Brasileiro.

4.1. Conceito de adimplemento substancial.

4.2. Atualidade referente à aplicação do adimplemento substancial.

4.3. O adimplemento substancial na vigência do Código Civil de 1916 e legislação anterior ao Código em vigor.

4.4. O adimplemento substancial e o Código de 2002.

5. Adimplemento substancial e a Teoria Geral das Obrigações e dos Contratos.

5.1. Teoria Geral das Obrigações.

5.1.1. O adimplemento substancial e as várias formas de inadimplemento.

5.2. Teoria Geral dos Contratos.

5.2.1. Do contrato em geral.

5.2.2. Princípios contratuais.

5.2.3. O princípio da boa-fé objetiva e o adimplemento substancial.

5.2.3.1. Da boa-fé objetiva.

5.2.3.2. A boa-fé objetiva aplicada ao adimplemento substancial.

5.2.4. A resolução da relação contratual e outros modos de extinção do contrato.

5.2.5. A resolução e o adimplemento substancial.

6. Inadimplemento parcial e o adimplemento substancial.

7. Elementos para identificação do adimplemento substancial. 237

7.1. A substancialidade da prestação efetivamente executada.

7.2. A satisfação do interesse do credor.

7.3. A diligência do devedor no cumprimento da prestação.

7.4. A insignificância do que não foi prestado.

7.5. A proporcionalidade aplicada aos contratos.

8. Questões acerca do adimplemento substancial.

8.1. O adimplemento substancial e a segurança jurídica.

8.2. O adimplemento substancial e a vedação ao enriquecimento sem causa.

8.3. O adimplemento substancial e o abuso de direito. 
9.1. Cumprimento substancial da obrigação contratual.

9.2. Satisfação do interesse do credor.

9.3. Restituição da parte inadimplida ao credor ou adimplemento posterior; bem como ressarcimento, se for o caso.

9.4. Manutenção da relação contratual.

9.5. Efeito liberatório do devedor.

9.6. Conclusão sobre os efeitos do adimplemento substancial.

10. Aplicação da teoria do adimplemento substancial.

10.1. Contrato de compra e venda.

10.2. Contrato de compromisso de compra e venda.

10.3. Contrato em que há alienação fiduciária.

10.4. Contrato de seguro.

10.5. Contrato de empreitada.

10.6. Contratos bancários e contrato de empréstimo.

10.7. Contrato de leasing.

11. Contribuição legislativa sobre o adimplemento substancial. 317

Conclusão.

Bibliografia.

Anexos. 


\section{O ADIMPLEMENTO SUBSTANCIAL NA EXECUÇÃO DO CONTRATO}

\section{Introdução.}

O presente trabalho objetiva analisar o adimplemento substancial no campo do Direito Privado, com preferência ao Direito Civil. Num primeiro passo, será investigado o histórico do adimplemento substancial, iniciando-se pelo Direito Romano, naquilo que se aproxima dessa figura jurídica; e em seguida, mostrando como surgiu a figura no sistema do Common Law, onde originariamente criou-se a figura da substantial performance.

No capítulo seguinte, será examinada a substantial performance no sistema do Common Law. Primeiramente, será apresentada a estrutura desse sistema angloamericano, para mostrar como a figura se comporta ali.

Após, será analisado o adimplemento substancial na atualidade, indicando-se como essa figura se apresenta na legislação e nas decisões dos tribunais dos países do sistema do Common Law, bem como nos países do sistema romanístico.

De fato, alguns ordenamentos jurídicos já instituíram essa figura. Assim, será examinado como o adimplemento substancial encontra-se no Direito comparado. No sistema romanístico-germânico-canônico, a figura será investigada no Direito Italiano, no Direito Português, no Direito Francês, no Direito Alemão, no Direito Espanhol e em outros, além da Convenção de Viena e demais convenções pertinentes.

Em seguida, será apresentada a atualidade dessa figura no sistema angloamericano, ou seja, no Direito Inglês e no Direito Norte-Americano. Por fim, será apontada sua inclusão no Direito Brasileiro. 
Logo depois, será necessário apresentar o conceito de adimplemento substancial. Com isso, será feita a sua ligação com a Teoria Geral das Obrigações e também com a Teoria Geral dos Contratos. Com efeito, o tema do adimplemento substancial insere-se no tópico da extinção das obrigações e aplica-se em grande parte aos contratos.

Numa primeira visão, quando se define o adimplemento substancial, fala-se de cumprimento da obrigação, mas esta não se dá com o pagamento tal qual essa obrigação determina, porém sem o cumprimento de parte ínfima dela. De fato, para Clóvis do Couto e Silva ${ }^{1}$, o adimplemento substancial constitui "um adimplemento tão próximo ao resultado final, que, tendo-se em vista a conduta das partes, exclui-se o direito de resolução, permitindo tão somente o pedido de indenização" e/ou de adimplemento, de vez que aquela primeira pretensão viria a ferir o princípio da boa-fé. Esse conceito será examinado mais adiante em capítulo próprio.

No tocante aos princípios regedores da matéria, o adimplemento substancial será abordado segundo essas normas. Como princípio informador do Direito, a boa-fé objetiva exerce papel relevante quanto à figura do adimplemento substancial. Incidindo no campo das Obrigações, é preciso compreender, por meio da boa-fé, a obrigação como um processo. De fato, todo negócio jurídico, que gera um vínculo obrigacional, é visto dinamicamente, pois nasce, sofre modificações e extingue-se. Em cada etapa, é preciso analisar como se dá o negócio jurídico e os princípios que o regem. $\mathrm{Na}$ fase extintiva, incide, por exemplo, o princípio da boa-fé objetiva, que vai conformar o chamado adimplemento substancial.

Miguel Reale ${ }^{2}$, quando coordenou o projeto do Código Civil em vigor, expôs que ele é regido pelos princípios da eticidade, socialidade e operabilidade. O primeiro, o princípio da eticidade, é o fundamento da boa-fé objetiva, porque somente o comportamento ético, como o de lealdade, confiança, segurança, cooperação, proteção, informação e solidariedade, pode permitir uma vida proba, honesta e adequada aos fins a que se propõe.

\footnotetext{
${ }^{1}$ COUTO E SILVA, Clóvis. Princípio da boa-fé no Direito Brasileiro e Português, 1980, p. 56.

${ }^{2}$ REALE, Miguel. O projeto do novo Código Civil, 1986, pp. 10 a 12.
} 
Entre os negócios jurídicos, sabe-se que os contratos são exemplos deles, pois são os que melhor os representam. Nesse sentido, como os contratos são regidos pelos princípios contratuais, a boa-fé objetiva desempenha papel relevante nesses casos. Assim, o adimplemento substancial, que é figura aplicada aos contratos, será abordado tendo em vista os princípios contratuais, principalmente o da boa-fé objetiva.

De fato, já se desenvolveu a tese de que os contratos são respaldados pela boa-fé objetiva, a qual limita todo contrato (são cláusulas gerais que servem também de interpretação e até de integração dele). O adimplemento substancial é resultado da aplicação desse princípio contratual.

A relação contratual vista pela boa-fé objetiva vai externar um comportamento leal e de confiança entre os contratantes, durante toda a execução do contrato e até mesmo na fase pré-contratual e na pós-contratual. Assim, tal cláusula geral pode objetivar que haja um real cumprimento do contrato, alcançando-se um equilíbrio na relação contratual e afastando-se o abuso nessa relação jurídica formada, se se pretende um negócio jurídico leal e seguro.

Por outro lado, outro princípio que se aplica à figura em tela é a função social, a qual se consubstancia na cláusula geral que impõe a preservação do contrato equilibrado, gerando uma tutela externa do crédito ou a conservação do negócio jurídico. Não se trata de dizer que a função social do contrato significaria a subordinação do exercício da liberdade contratual aos interesses da sociedade, mas tão somente de ver que a função social impõe limites ao contrato ${ }^{3}$. Assim, os princípios da autonomia privada, da obrigatoriedade, da relatividade dos efeitos do contrato e do consensualismo foram mitigados pela função social e pela boa-fé objetiva.

Já a justiça contratual contribui quando preserva o equilíbrio entre as partes quanto à troca de bens, interesses, direitos e deveres, garantindo que o contrato exerça seu papel fundamental de regular os interesses das partes contratantes, mas também de atender aos interesses da sociedade, que podem limitar aqueles.

\footnotetext{
${ }^{3}$ ZANETTI, Cristiano de Sousa. Direito Contratual Contemporâneo - a liberdade contratual e sua fragmentação, 2008, p. 199.
} 
O que se pretende aqui nesta tese é mostrar que o adimplemento substancial é resultado de uma aplicação mais ampla desses princípios norteadores dos contratos. Todavia, não se pode olvidar que o contrato, visto como instrumento de auto-regulação das partes, vai interferir nas relações sociais, ao distribuir justiça entre as partes e terceiros (quando isso for reclamado). A força obrigatória dos contratos está presente, mas mitigada, quando o cumprimento do contrato já se torna suficiente, desconsiderando-se parte ínfima do pagamento integral.

Nessa perspectiva, pode-se acrescentar que os usos e costumes também exercem papel relevante na construção do contrato, por darem conformação ao modo por que se criam negócios e se regulam interesses. O adimplemento substancial tem sido considerado na jurisprudência como resultado desse modo de cumprimento das obrigações.

Quando se fala numa doutrina ${ }^{4}$ do adimplemento substancial, há um consenso no sentido de que o tema abarca: o conceito de obrigação como um processo, o papel do princípio da boa-fé objetiva no campo contratual, a funcionalização do direito de crédito e o interesse do devedor e a influência da figura do abuso do direito, além da teoria da causa, como função econômico-social do contrato.

Mais adiante, vamos apresentar o contrato civil de forma geral. Nesse sentido, o contrato é fonte geradora de relação jurídica. No entanto, antes mesmo disso, o contrato não pode ser tomado apenas como um negócio jurídico obrigacional, mas como um negócio jurídico mais amplo (como o contrato de casamento, v.g.), que decorre das relações formadas no mundo econômico, social e político.

O contrato do ponto de vista jurídico gera uma relação jurídica, revestida ou não de instrumento, mas produtor de direitos e deveres para as partes, o que regula a vida e o interesse patrimonial delas em sociedade. ${ }^{5}$

\footnotetext{
${ }^{4}$ BECKER, Anelise. A doutrina do adimplemento substancial no Direito brasileiro e em perspectiva comparativista, 1993, p. 60.

${ }^{5}$ MESSINEO, Francesco. I Contratti in generi, Trattato di Diritto Civile e Commerciale, $4^{\text {a }}$ edição, 1981. O autor italiano mostra que o contrato não é somente obrigacional, mas também pertence a outros ramos do Direito.
} 
Como fonte de obrigação, o contrato pode ser encarado dinamicamente, e não somente estaticamente ${ }^{6}$. Numa contratação, os contratantes passam por uma fase de tratativas (negociações preliminares), depois passam à conclusão ou aperfeiçoamento do contrato, o qual será executado até o seu desfazimento (extinção do contrato); por fim, restam ainda as obrigações pós-contratuais.

Em todas essas etapas, aplicam-se cláusulas gerais como a boa-fé objetiva ou a função social do contrato; e nelas também se encontra a justiça comutativa. E, decorrente dessas, a possibilidade de intervenção judicial no negócio jurídico criado pelas partes.

Pode-se dizer que essas figuras jurídicas são verdadeiras normas de interpretação do contrato, capazes de limitar a autonomia da vontade ${ }^{7}$ das partes, mas podem funcionar também como normas que criam deveres anexos, além de constituírem normas limitadoras ou proibitivas de condutas.

Outrora, o contrato era resultado da vontade das partes ${ }^{8}$. Hoje, o contrato, embora introduza no sistema jurídico novas normas regedoras de condutas, convive

\footnotetext{
${ }^{6}$ COUTO E SILVA, Clóvis. A Obrigação como processo, loc. cit. na bibliografia, 2010, in totum. O autor mostra que a obrigação deve ser vista como um processo, isto é, de forma dinâmica. Assim, os princípios contratuais, por exemplo, atuam em todas as fases da contratação, o que corrige dispositivos legais, como o da boa-fé objetiva, contida no artigo 422 do Código Civil. Da mesma forma, na obrigação, credor e devedor devem atuar, ao longo da duração do negócio jurídico, de acordo com tais princípios.

${ }^{7}$ Adota-se atualmente o princípio da autonomia privada, em que aquela ampla liberdade contratual, típica do liberalismo econômico, é exercida agora dentro de determinados limites.

${ }^{8}$ Em um resumo bem rudimentar, pode-se afirmar que, no Direito Romano, o contrato era entendido como um pacto revestido de força coercitiva (nexus), dependendo do consentimento das partes para a sua concretização (Gaius: solo consensus) ou da traditio, isto é, a entrega da coisa. Pelo Direito Germânico, considerava-se a palavra dada como importante para a formação do contrato consensual. Já o Direito Canônico, baseado nos preceitos cristãos, incorporou a ideia de que só se deve firmar negócios que tenham condutas dentro dos dogmas cristãos (a teoria geral das obrigações que vinha do próprio Direito Romano compunha uma das fontes do Direito Canônico; vide GILISSEN, John, Introdução Histórica ao Direito, loc. cit. na bibliografia, 2001). Na Era Moderna, o contrato passou a fundamentar os interesses civis professados pelo liberalismo, principalmente os daqueles que detinham o poder (Michel Villey, Direito Romano, pág. 164, diz que os contratos teriam por alma o consentimento) e eram resultados da autonomia da vontade dos contratantes, segundo ideias difundidas por Kant. Atualmente, o contrato, que sofreu uma objetivação nas suas relações entre as partes, decorrente de uma produção em escala e em massa, é fonte de norma jurídica segundo o interesse das partes, mas dentro de um conjunto de princípios, agora contidos na constituição, da qual se pode extrair o da socialidade, a qual passa a limitar ou proibir condutas contrárias ao interesse coletivo, ou ainda o da eticidade, da qual se extrai a boa-fé objetiva, cláusula aberta e fonte de interpretação, limitação e integração do negócio jurídico.
} 
com essas figuras que limitam, ou orientam comportamentos segundo uma ordem jurídica aceita por todos. ${ }^{9}$

Nesse passo, será examinado o adimplemento substancial aplicado ao contrato, considerando a maneira pela qual seus efeitos, não somente em relação às partes, podem repercutir na sociedade. Isso se dá muitas vezes com a função social do contrato, quando, embora o contrato seja existente, válido e apto a produzir seus efeitos, pode ser limitado por ofender sua função social. ${ }^{10} \mathrm{Em}$ outras palavras, a função econômica e social, que caracteriza a causa do tipo negocial, segundo a autonomia privada, determina o conteúdo mínimo desse negócio tipo, mas é limitada quando discrepa dessa função.

Como diz Miguel Reale ${ }^{11}$, esse preceito fundamental é essencial à adequação das normas à concreção ética da experiência jurídica.

Como o adimplemento substancial aplica-se aos contratos, aquele será abordado à luz destes e seus princípios. Na evolução histórica do contrato, os princípios contratuais sofreram alterações. Não foi à toa que certa doutrina italiana ${ }^{12}$ mostrou que, ao contrato, aplica-se o princípio da autonomia privada, para afastar o dogma da autonomia da vontade. Da mesma forma, são cabíveis o princípio da boa-fé, bem como o da função social do contrato, os quais dão um novo contorno ao campo contratual. Outra tese ${ }^{13}$, ainda, afastou a alegação de que o contrato havia morrido, porque as partes não mais manifestavam sua vontade para criar determinados negócios contratuais. Enzo Roppo ${ }^{14}$ mostra que a teoria da vontade, bem como a teoria da declaração, deram lugar a uma "objetivação" do contrato, principalmente numa sociedade baseada na economia de massa.

\footnotetext{
${ }^{9}$ As relações contratuais sofreram um abalo no equilíbrio entre as partes, principalmente com o surgimento de atividades econômicas de grande escala e produção em massa. Daí, uma transformação de regramentos que procuraram proteger a parte mais vulnerável nessas relações.

${ }^{10}$ Imagine-se a locação de um imóvel em que se pretenda o depósito de lixo tóxico, v.g. Esse contrato, embora existente, válido e apto a produzir efeitos, encontra-se em frontal ofensa à sua função social.

${ }^{11}$ REALE, Miguel, História do novo Código Civil, pp. 92-93.

${ }^{12}$ Vide BETTI, Emilio. Teoria generale del negozio giuridico, 2002, pp. 43-74 e 101-113; ROPPO, Enzo. O Contrato, 1988, pp. 295-348; FERRI, Luigi. L'Autonomia Privata, 1959, pp. 1-9. Esses autores italianos trataram do princípio da autonomia privada para afastar o dogma da autonomia da vontade e mostrar as questões relativas à limitação da liberdade contratual.

${ }^{13}$ GILMORE, Grant. The death of contract, loc. cit., 1995, in totum.

${ }^{14}$ ROPPO, Enzo. O Contrato, 1988, p. 297.
} 
Assim, a obrigatoriedade do contrato que surge em razão da autonomia da vontade cede lugar à convivência de outros princípios aplicáveis que também passam a dirigir o contrato, como aquelas cláusulas gerais mencionadas acima.

O fato é que o contrato representa um dos melhores instrumentos para ajuste de direitos e obrigações, que pode propiciar a circulação de bens, a concretização de interesses e a padronização de comportamento necessário à segurança das relações sociais ${ }^{15}$.

Deve-se trazer aqui também a figura do abuso de direito aplicada aos casos de direitos de crédito. Isso porque em determinadas relações jurídicas, uma das partes exerce um direito, de forma que excede manifestamente os limites impostos pelo negócio jurídico, conforme o seu fim econômico ou social, pela boa-fé objetiva ou pelos bons costumes. Por essa razão, o adimplemento substancial não pode significar uma conduta abusiva quando do cumprimento da obrigação contratual, porque as partes devem agir de acordo com o negócio avençado, não excedendo seus limites.

Ademais, o adimplemento substancial deve ser analisado segundo a causa do negócio jurídico, ou seja, a função econômico-social do contrato. Com efeito, Emilio Betti ${ }^{16}$ diz que "a causa do negócio é, propriamente, a função econômico-social que caracteriza o tipo desse negócio como fato de autonomia privada (típica, neste sentido), e lhe determina o conteúdo mínimo necessário". Limita, assim, a autonomia privada, pois a tutela jurídica desta "toma em conta, não o capricho individual, mas apenas a função socialmente relevante do negócio-tipo, considerada em si e por si".

Em suma, a presente tese de doutorado aborda tema da atualidade no Direito Civil moderno. A figura do adimplemento substancial pode ser tida como resultado da boa-fé objetiva, da função social e da justiça contratual. Assim, será investigada a

\footnotetext{
${ }^{15}$ GOMES, Orlando. Contratos, 1992, p. 22. O autor vai mais além, entendendo que a função econômica do contrato permite, além da circulação de riquezas; a colaboração; a prevenção de risco; de conservação e acautelatórios; para prevenir ou dirimir uma controvérsia; para a concessão de crédito; constitutivos de direitos reais de gozo, ou de garantia.

${ }^{16}$ BETTI, Emilio. Teoria generale del negozio giuridico, loc. cit., 2002, pp. 181 e ss.
} 
necessária conexão entre boa-fé objetiva, função social e justiça contratual, todas aplicadas ao adimplemento substancial nos contratos civis.

No bojo dessa investigação, serão analisados casos concretos em que se aplica a teoria do adimplemento substancial, tanto na teoria e na jurisprudência pátrias, quanto nas estrangeiras, apontando críticas e acertos dessa aplicação da figura jurídica em tela.

Entre as principais questões a respeito deste tema, surge a indagação de saber se o adimplemento substancial ofende a segurança jurídica, ou se atende às exigências do cumprimento obrigacional, sem que haja enriquecimento injusto da parte cumpridora dos deveres contratuais, bem como sem abuso no exercício desse direito.

Qual o alcance dessa figura jurídica, quanto às etapas não somente de formação e execução do contrato e sua evidente extinção geradora de responsabilidade contratual ou não? Aqui, o adimplemento substancial será examinado quantos aos seus efeitos, bem como no tocante à aplicação da teoria respectiva em função de determinados contratos em espécie, extraídos da experiência brasileira atual.

Essas são algumas questões a serem abordadas ao longo do presente trabalho.

Quanto à principal contribuição à ciência jurídica, tem-se uma nova interpretação do adimplemento substancial, relativa à aplicação dessa figura na execução dos contratos, segundo sua inserção no campo das obrigações e também do âmbito contratual, bem como de seus efeitos. Em outras palavras, é a verificação da figura jurídica no enquadramento da Teoria Geral das Obrigações e dos Contratos.

Além disso, será apresentada uma contribuição legislativa sobre o tema, com suas justificativas.

Assim, pretende-se contribuir com essa pesquisa e investigação do tema para ampliar o entendimento do Direito das Obrigações e dos Contratos. Note-se que o adimplemento substancial surge como uma figura jurídica de tratamento relativo à gravidade ou à importância do cumprimento da prestação. Se for insignificante seu 
cumprimento, de maneira que o credor ainda tenha interesse na prestação oferecida embora uma pequena parte seja desconsiderada, o contrato pode ser extinto em razão do cumprimento da obrigação contratual na sua substância. Esse tema será desenvolvido ao longo desta obra.

Ademais, será oferecida uma pesquisa sobre a figura jurídica e seu alcance no Direito brasileiro, analisando-se como os tribunais pátrios tem adotado essa figura no campo do Direito Privado, segundo uma premissa a ser definida no corpo desta tese e verificar o comportamento desses Tribunais nesse quesito.

Em suma, será realizada uma análise investigativa do adimplemento substancial aplicada ao contrato, como forma de fixação de conceitos e de reconstrução de ideias sobre o tema. 


\section{Conclusão.}

A presente tese analisou o adimplemento substancial no Direito Civil. Foi investigada essa figura jurídica no Direito Romano e suas origens no sistema do Common Law. Em seguida, ela foi examinada no sistema romanístico e no sistema anglo-americano, focando-se na sua atualidade, até apresentá-la no Direito Brasileiro, principalmente quanto aos seus elementos de identificação, diferenças com outras figuras semelhantes, questões pertinentes ao tema, efeitos, e sua aplicação nos tribunais brasileiros.

Depois dessa longa investigação, é preciso esclarecer o propósito desta tese.

Com efeito, a principal proposta desta obra foi expandir os horizontes da teoria do adimplemento substancial. Essa figura jurídica, com todo respeito aos doutrinadores pátrios, foi tratada apenas em alguns dos aspectos dela. São poucas as obras que mostraram as suas origens, principalmente no sistema romanístico e muitas delas enfocam o adimplemento substancial como uma extensão do Direito angloamericano. É preciso fazer sempre uma adaptação ao sistema brasileiro, que tem fundamentos próprios. Por exemplo, o contrato naquele sistema é apenas uma promessa, ao passo que no sistema brasileiro o contrato, como negócio jurídico, tem que passar pelo plano de validade, até por força de lei (CC, art. 104). Assim, a aplicação do adimplemento substancial na execução do contrato depende desse enquadramento legal.

Assim, procurou-se apresentar a substantial performance no Direito AngloAmericano, mostrando-se primeiramente a estrutura do sistema do Common Law, para depois examinar o funcionamento dessa figura ali e o resultado prático da aplicação dessa teoria nesse sistema, como ponto de referência à aplicação ao Direito Brasileiro.

Após, foi analisado o adimplemento substancial na atualidade e apresentou-se essa figura na legislação e nas decisões dos tribunais dos países do sistema romanístico, bem como nos países do sistema do Common Law, como uma forma de dar os 
contornos da teoria em apreço nas suas variantes no sistema romanístico principalmente, porque nesse sistema não se adota a figura do adimplemento substancial, mas do inadimplemento de escassa importância, o qual afasta a aplicação da resolução do contrato.

Em razão desse enfoque acima, foi possível propor um conceito de adimplemento substancial.

O conceito adotado nesta tese é o de que o adimplemento substancial consiste no cumprimento da obrigação contratual em que se despreza parte de menor gravidade descumprida, tendo em vista o interesse do credor e a economia do contrato, excluindo o direito de resolução, mas permitindo-se ao credor uma indenização pela parte faltante ou o oportuno cumprimento dessa parte de escassa importância.

A figura do adimplemento substancial tem fundamento nos princípios da boa-fé objetiva, no da função social, no da conservação do contrato e afastamento do abuso de direito e do enriquecimento sem causa. Trata-se de uma interpretação fundada principalmente na boa-fé objetiva e na função social ${ }^{425}$ na execução do contrato.

Por outro lado, ao tratar-se duma doutrina ${ }^{426}$ do adimplemento substancial, há uma concordância no sentido de que o tema compreende alguns pontos examinados: o conceito de obrigação como um processo, o papel do princípio da boa-fé objetiva no campo contratual, a funcionalização do direito de crédito e o interesse do devedor e a influência da figura do abuso do direito, além da teoria da causa, como função econômico-social do contrato.

Enfocando a figura do adimplemento substancial no campo dos contratos, foram apontadas sua incidência e suas consequiências. De fato, o contrato do ponto de vista

\footnotetext{
425 Aqui é importante ressaltar que há autores críticos tanto à boa-fé, como Salvatore Satta, quanto à função social do contrato, como a Profa. Daisy Gogliano (GOGLIANO, Daisy. A função social do contrato (causa e motivo), in Revista da Faculdade de Direito da USP, v. 99, São Paulo, pp. 153-198, 2004). Aquele minimiza a aplicação da boa-fé objetiva ao contrato. Esta doutrinadora, por sua vez, entende que a função social aplica-se à propriedade, mas não ao contrato, porque este cria uma relação privada entre partes e não teria o condão de alcançar a sociedade.

${ }^{426}$ BECKER, Anelise. A doutrina..., op. cit., 1993, p. 60.
} 
jurídico gera uma relação jurídica obrigacional ${ }^{427}$, revestida ou não de instrumento, mas que produz direitos e deveres para as partes e isso vai regular a vida e o interesse patrimonial delas em sociedade. Nesse sentido, o contrato gera obrigações e é precisamente por isso que ele admite o adimplemento substancial, como figura que leva à extinção da obrigação, mas evita a resolução do contrato, pois considera que houve o cumprimento substancial da prestação, desprezando-se parte ínfima descumprida.

Ademais, no campo contratual, o princípio da boa-fé objetiva exerce forte papel na figura do adimplemento substancial. De fato, inserida no campo das Obrigações, a figura foi examinada segundo a concepção de que a obrigação é um processo. Nesse sentido, o negócio jurídico foi visto dinamicamente, em cada fase de sua existência: nascimento, modificações e sua extinção. Em cada etapa, os princípios incidem no negócio jurídico, de maneira que, na fase extintiva, o princípio da boa-fé objetiva vai consubstanciar o chamado adimplemento substancial.

Como decorrência da ideia de eticidade, a boa-fé objetiva é fundamento dos contratos, porque somente o comportamento ético, como o de lealdade, confiança, segurança, cooperação, proteção, informação e solidariedade, pode permitir uma vida proba, honesta e adequada aos fins a que se propõe, principalmente no campo contratual. $^{428}$

Em outras palavras, os contratos são regidos pelos princípios contratuais e o da boa-fé objetiva desempenha papel relevante nesses negócios jurídicos. Assim, o adimplemento substancial torna-se conseqüência desse princípio. Isso porque os contratos são respaldados pela boa-fé objetiva, a qual limita todo contrato (são cláusulas gerais que servem também de interpretação e até de integração dele). O adimplemento substancial é resultado da aplicação desse princípio contratual, porque o devedor realiza

\footnotetext{
${ }^{427}$ Não se ignora que o contrato não é figura exclusiva do campo civil das obrigações. Vide MESSINEO, Francesco, in I Contratti in generi, Trattato di Diritto Civile e Commerciale, $4^{\mathrm{a}}$ edição, Milano: Giuffrè Editore, 1981.

${ }^{428}$ Reconhece-se que há autores (como o jurisconsulto Paulo, até Kelsen e, entre nós, Eduardo Bittar e Guilherme Assis de Almeida, bem como Jeannette Antonios Maman, com outro enfoque, vg.) que separam claramente o que é do Direito e o que pertence à Moral. Entretanto, o autor desta tese entende que há uma relação mais íntima entre os dois campos de atuação humana, de modo que se pretende uma sociedade calcada em valores éticos cardeais e no Direito.
} 
a prestação com diligência e lealdade, embora ocorra a dispensa de uma parte de escassa importância, desde que haja interesse ao credor e não afete a economia do contrato.

A relação contratual vista pela boa-fé objetiva vai externar um comportamento leal e de confiança entre os contratantes, durante toda a execução do contrato e até mesmo na fase pré-contratual e na pós-contratual. Assim, tal cláusula geral pode objetivar que haja um real cumprimento do contrato, alcançando-se um equilíbrio na relação contratual e afastando-se o abuso nessa relação jurídica formada, se se pretende um negócio jurídico leal e seguro.

Por outro lado, outro princípio que se aplica à figura em tela é a função social, a qual se consubstancia na cláusula geral que impõe a preservação do contrato equilibrado, gerando uma tutela externa do crédito, como também a conservação do negócio jurídico. $\mathrm{O}$ adimplemento substancial evita o desfazimento do contrato e o retorno das partes ao status quo ante, conservando o contrato, pois considera que a obrigação contratual foi cumprida, ainda que haja parte de pouca importância descumprida.

Note-se que a função social do contrato não significa a subordinação do exercício da liberdade contratual aos interesses da sociedade, mas que essa função social impõe limites ao contrato, principalmente quanto ao acerto sobre o conteúdo dele.

De fato, a função social aplica-se ao contrato e pode limitar o negócio cujo conteúdo seja ofensivo ao interesse da coletividade. Embora o contrato seja existente, válido e apto a produzir seus efeitos, ele pode ser limitado por haver ofensa a sua função social. Em outras palavras, a função econômica e social, que caracteriza a causa do tipo negocial, segundo a autonomia privada, determina o conteúdo mínimo desse negócio tipo, mas é limitada quando discrepa dessa função.

Esses princípios contratuais exerceram forte influência sobre os demais. Assim, os princípios da autonomia privada, da obrigatoriedade, da relatividade dos efeitos do contrato e do consensualismo foram mitigados pela função social e pela boa-fé objetiva. Daí falar-se no adimplemento substancial, que mitiga a obrigatoriedade do contrato, 
quando admite um adimplemento diverso do que o puro e simples cumprimento integral da obrigação contratual, ainda que mais gravoso ao devedor.

Já a justiça contratual contribui quando preserva o equilíbrio entre as partes quanto à troca de bens, interesses, direitos, deveres, garantias, pretensões, assegurando que o contrato exerça seu papel fundamental de regular os interesses das partes contratantes, mas também de atender aos interesses da sociedade, que podem limitar aqueles.

Assim, em face desses princípios contratuais, o adimplemento substancial é resultado de uma aplicação mais ampla desses princípios norteadores dos contratos. Entretanto, o contrato, visto como instrumento de auto-regulação das partes, vai interferir nas relações sociais, ao distribuir justiça entre as partes e até para terceiros, se for o caso. Com efeito, a força obrigatória dos contratos está presente, mas mitigada, quando o cumprimento do contrato já se torna suficiente, desconsiderando-se parte ínfima do pagamento integral.

O fato é que o contrato representa um dos melhores instrumentos para ajuste de direitos e obrigações, que pode propiciar a circulação de bens, a concretização de interesses e a padronização de comportamento necessário à segurança das relações sociais, bem como uma relação equilibrada entre as partes contratantes. Assim, a resolução do contrato significa uma forma gravosa ao devedor que cumpre o contrato substancialmente, embora haja parte ínfima descumprida.

Orlando Gomes ${ }^{429}$, por exemplo, disse que a função econômica do contrato ${ }^{430}$ permite, além da circulação de riquezas, a colaboração; a prevenção de risco; de conservação e acautelatórios; para prevenir ou dirimir uma controvérsia; para a concessão de crédito; constitutivos de direitos reais de gozo, ou de garantia. Se o contrato não admitisse $\mathrm{o}$ adimplemento substancial, não cumpriria essa função econômico-social, pois agravaria a situação econômica do devedor.

\footnotetext{
${ }^{429}$ GOMES, Orlando. Contratos, op. cit., 1992, p. 22.

430 ARAÚJO, Fernando. Teoria Econômica do Contrato, Coimbra: Editora Almedina, 2017. Vide também ALPA, Guido. Interpretazione Economica del Diritto, in Rivista del Diritto Commerciale, Milano: Casa Editrice Dottor Francesco Vallardi, anno LXXIX, 1981.
} 
Ademais, o adimplemento substancial foi analisado segundo a causa do negócio jurídico, ou seja, a função econômico-social do contrato. Utilizando-se o conceito de Emilio Betti ${ }^{431}$, esse autor italiano disse que "a causa do negócio é, propriamente, a função econômico-social que caracteriza o tipo desse negócio como fato de autonomia privada (típica, neste sentido), e lhe determina o conteúdo mínimo necessário". Em consequência, ele limita a autonomia privada, pois a tutela jurídica desta "toma em conta, não o capricho individual, mas apenas a função socialmente relevante do negócio-tipo, considerada em si e por si". Essa causa do negócio vai delinear a prestação a ser realizada no negócio e aqui que o adimplemento substancial se insere, pois o cumprimento da obrigação deve atender aquele conteúdo mínimo necessário, tanto às partes, quanto à coletividade.

Outro ponto relevante acerca do propósito da tese foi delimitar o campo de aplicação do adimplemento substancial e o da resolução. Assim, após o exame do adimplemento substancial na Teoria Geral das Obrigações e dos Contratos, tratou-se inicialmente da resolução do contrato e outras formas de extinção do contrato; em seguida, foram analisadas as várias formas de inadimplemento; até cuidar da resolução e o adimplemento substancial, ponto em que ficou evidente que esta figura afasta a resolução do contrato. Em outras palavras, o adimplemento substancial leva à mitigação da aplicação da resolução. ${ }^{432}$

\section{E em tópico separado, foi examinada também a figura do inadimplemento} parcial e do adimplemento substancial, para mostrar que esta aparenta-se com aquela, mas seus efeitos são diversos, por consideração ao equilíbrio contratual e à justiça na relação contratual. De fato, o adimplemento substancial assemelha-se ao adimplemento parcial (ou seu reverso, o inadimplemento parcial) na sua aparência externa. Todavia, diferem-se no seu aspecto interno, uma vez que, em razão da interpretação que se faz por meio do princípio da boa-fé objetiva e da função social, pode-se considerar que não haja gravidade suficiente na parte de escassa importância que foi descumprida capaz de levar à resolução do contrato.

\footnotetext{
${ }^{431}$ BETTI, Emilio. Teoria generale del negozio giuridico, op. cit., pp. 181 e sgg.

${ }^{432}$ Note-se que, historicamente, o afastamento da resolução em face do inadimplemento de pequena gravidade ou escassa importância já estava previsto no projeto de lei de Orosimbo Nonato, como foi mencionado no capítulo acerca do Direito Brasileiro. Portanto, não é uma novidade.
} 
Numa perspectiva original da tese, foram apresentados os elementos para identificação do adimplemento substancial, a saber, a substancialidade da prestação efetivamente executada; a satisfação do interesse do credor, apesar da prestação imperfeita; diligência do devedor no cumprimento da prestação, ou seja, inexistência de culpa do devedor ao executar o contrato; proporcionalidade na aferição do quanto cumprido pelo devedor; e insignificância ou escassa importância do que o devedor deixou de prestar.

Num outro passo, foram indicadas questões acerca do adimplemento substancial: o adimplemento substancial e a segurança jurídica; o adimplemento substancial e a vedação ao enriquecimento sem causa; e por fim, o adimplemento substancial e o abuso de direito.

Deve-se ressaltar a figura do abuso de direito aplicada aos casos de direitos de crédito. De fato, em determinadas relações jurídicas, uma das partes exerce um direito, de forma que excede manifestamente os limites impostos pelo negócio jurídico, conforme o seu fim econômico ou social, pela boa-fé objetiva ou pelos bons costumes.

Entre essas questões a respeito deste tema, indagou-se se o adimplemento substancial atende às exigências do cumprimento obrigacional, sem que haja enriquecimento injusto da parte cumpridora dos deveres contratuais e sem abuso no exercício desse direito. Além disso, mostrou-se qual o alcance dessa figura jurídica, quanto às etapas não somente de formação e execução do contrato, bem como de sua evidente extinção geradora de responsabilidade contratual ou não, concluindo que o adimplemento substancial extingue o contrato, embora se admita que parte de escassa importância possa ser executada posteriormente.

Ademais, mostrou-se como se dá a aplicação da teoria do adimplemento substancial nos tribunais brasileiros. Assim, foi oferecida uma pesquisa sobre a figura jurídica e seu alcance no Direito brasileiro, apontando-se criticamente como os tribunais pátrios têm adotado essa figura no campo do Direito Privado, considerando a curta vigência do Código Civil. 
Nesse ponto, ficou evidente que a quantificação da chamada escassa importância do descumprimento da obrigação contratual é criticável, porque não há um critério objetivo e único para se apurar a medida certa que leva à desconsideração da parte inadimplida na execução de cada contrato. Para isso, os julgadores tem se utilizado do critério da proporcionalidade, ou da própria boa-fé objetiva (nesse mesmo aspecto).

Ademais, o julgador deve não só observar o critério quantitativo, mas principalmente o qualitativo, pois este pode definir melhor se a parte descumprida é caso de pequena gravidade ou não.

Por fim, frise-se que outro propósito desta tese foi apresentar, de forma inédita, uma contribuição legislativa, para positivação do adimplemento substancial na lei civil, em que se fez uma breve exposição dos motivos que fundamentam sua importância jurídica.

Em suma, foi realizada uma análise investigativa do adimplemento substancial na execução do contrato, principalmente no âmbito civil, mostrando seus fundamentos jurídicos, sua aplicabilidade e seus efeitos, fixando-se conceitos e demonstrando sua importância na atualidade. 


\section{BIBLIOGRAFIA}

AFONSO DA SILVA, José. Constituição e Segurança Jurídica. In Constituição e segurança jurídica: direito adquirido, ato jurídico perfeito e coisa julgada, Estudos em homenagem a José Paulo Sepúlveda Pertence, Coord. Cármen Lúcia Antunes, $2^{\text {a }}$ edição, Belo Horizonte: Fórum, 2005.

AFONSO DA SILVA, L. Virgílio. O Proporcional e o Razoável, in Revista dos Tribunais no 798, São Paulo: Revista dos Tribunais, pp. 23-50, 2002.

Direitos fundamentais - conteúdo essencial, restrições e eficácia, $2^{\mathrm{a}}$ edição, São Paulo: Editora Malheiros, 2010.

------- Comparing the Incommensurable: Constitutional Principles, Balancing and Rational Decision, Oxford Journal of Legal Studies, vol. 31, no 2, pp. 273-301, 2011 (Disponível em: doi:10.1093/ojls/gqr004).

Ponderação e objetividade na interpretação constitucional, in MACEDO JR., Ronaldo Porto; CORTADA BARBIERI, Catarina Helena (org.), Direito $e$ interpretação: racionalidades e instituições, São Paulo: Editora Saraiva, 2011.

AGUIAR JÚNIOR, Ruy Rosado de. Extinção dos contratos por inadimplemento, $4^{\mathrm{a}}$ edição, São Paulo: Editora Revista dos Tribunais, 2004.

ALEINIKOFF, Thomas Alexander. Constitutional Law in the Age of Balancing, Yale Law Journal, nº 96, pp. 943-1005, 1987.

ALEXY, Robert. La formula del peso, in CARBONELL, Miguel (ed.), El principio de proporcionalidad y la interpretación constitucional, pp. 13-42. 
------- John Rawls' Theorie der Grundfreiheiten, in HINSCH, W. (ed.) et al., Zur Idee des politischen Liberalismus, Suhrkamp, Frankfurt A. M., pp. 282 e ss., 1997.

Teoria dos direitos fundamentais, tradução de Virgílio Afonso da Silva, $2^{\text {a }}$ edição, São Paulo: Malheiros, pp. 85-180, 2015.

Constitutional Rights and Proportionality, in Journal for Constitutional Theory and Philosophy of Law/Revija za ustavno teorijo in filozofijo prava, $\mathrm{n}^{\circ} 22$, pp. 51-65, 2014.

ALMEIDA COSTA, Mário Julio de. Aspectos modernos do Direito das Obrigações, in Estudos de Direito Civil Brasileiro e Português, São Paulo: Revista dos Tribunais, pp.75-101.

------ Direito das Obrigações, 12a edição, Coimbra: Almedina, pp. 1043-1087.

ALPA, Guido. Interpretazione Economica del Diritto, in Rivista del Diritto Commerciale, Milano: Casa Editrice Dottor Francesco Vallardi, anno LXXIX, 1981.

ALPA, Guido e BESSONE, Mario. Causa e consideration, Padova: Cedam-Casa Editrice Dott. Antonio Milani, 1984.

ALVAREZ VIGARAY, Rafael. La resolución de los contratos bilaterales por incumplimiento, Universidade de Granada, 1972.

ALVES, Jones Figueiredo. A teoria do Adimplemento Substancial ("Substantial Performance") do negócio jurídico como elemento impediente ao direito de resolução do contrato, in Novo Código Civil: questões controvertidas, Série Grandes Temas de Direito Privado, vol. 4, São Paulo: Método, 2005.

ALVES, José Carlos Moreira. Direito Romano, vols. I e II, $13^{\mathrm{a}}$ e $6^{\mathrm{a}}$ edições respectivamente, Rio de Janeiro: Editora Forense, 2003. 
ALVIM, Agostinho. Da inexecução das obrigações e suas conseqüências, Editora Jurídica e Universitária, 1965.

AMARAL JÚNIOR, Alberto do. A solução de controvérsias na OMC, São Paulo: Editora Atlas, 2008.

AMARAL, Antonio Carlos Rodrigues do (coord.). Direito do Comércio Internacional Aspectos Fundamentais, São Paulo: Edições Aduaneiras e Lex Editora, 2004.

ANDRADE, Fábio Siebeneichler. Causa e 'consideration', artigo publicado na Revista Ajuris, vol. 53, Porto Alegre-RS, 1991.

ANDREOLI, Giuseppe. Appunti sulla clausola risolutiva espressa e sul termine essenziale, in Rivista Trimestrale di Diritto e Procedura Civile, Milano: Dott. A. Giuffrè Editore, anno IV, pp. 72-89, 1950.

ARAÚJO, Fernando. Teoria Econômica do Contrato, Coimbra: Editora Almedina, 2017.

ASSIS, Araken. Resolução do contrato por inadimplemento, São Paulo, Revista dos Tribunais, 1999.

ATIYAH, Patrick Selim. An Introduction to the Law of Contract, $5^{\circ}$ edição, Oxford: Clarendon Press, 1996.

------- The Rise and Fall of Freedom of Contract, Oxford University Press, Oxford, 1985.

AULETTA, Giuseppe Giacomo. Importanza delll'inadempimento $e$ diffida ad adempiere, in Rivista Trimestrale di Diritto e Procedura Civile, Milano: Dott. A. Giuffré Editore, anno IX, pp. 655-676, 1955. 
------- La risoluzione per inadempimento, Studi di Diritto Privato, Edizione Scientifiche Italiane, vol. 16, Milano: Dott. A. Giuffrè Editore, 1942.

ÁVILA, Humberto. Teoria dos princípios - da definição à aplicação dos princípios jurídicos, 13ª edição, São Paulo: Editora Malheiros, 2012.

AZEVEDO, Antônio Junqueira de. Negócio Jurídico - Existência, Validade e Eficácia, $3^{\mathrm{a}}$ edição, São Paulo: Editora Saraiva, 2000.

Negócio Jurídico e Declaração Negocial, Edição independente, Universidade de São Paulo, 1986.

------ O princípio da Boa-fé nos contratos. Artigo escrito para o Curso de Pósgraduação da Faculdade de Direito da USP, s/d.

AZEVEDO, Luis Carlos de. Introdução à História do Direito, São Paulo: Editora Revista dos Tribunais, 2010.

BAPTISTA, Luiz Olavo. Dos Contratos Internacionais - Uma Visão Teórica e Prática. São Paulo: Editora Saraiva, 1994.

BARAK, Aharon. Proportionality, in ROSENFELD, Michael (ed.), SAJO, András (ed.), The Oxford Handbook of Comparative Constitutional Law, pp. 657-673, 2012 (DOI: 10.1093/oxfordhb/9780199578610.013.0036).

BARASSI, Ludovico. La teoria generale delle obligazioni, t. III, Milano, 1948.

BARCELLONA, Pietro. Intervento statale e autonomia privata nella disciplina dei rapporti economici, Milano: Dott. A. Giuffrè Editore, 1969.

BECK, Anthony. The doctrine of Substantial Performance: conditions and conditions precedent. The Modern Law Review, Oxford, v. 38, nº 4, pp. 413-428, jul., 1975. 
BECKER, Anelise. A doutrina do adimplemento substancial no Direito brasileiro e em perspectiva comparativista, in Revista da Faculdade de Direito da Universidade Federal do Rio Grande do Sul, vol. 9, nº 1, nov., 1993.

BERLIOZ, Georges. Le contrat d'Adhésion, Librairie Generale de Droit et de Jurisprudence, Paris, 1973.

BERTINO, Lorenzo. Le clausole sulla non scarsa importanza dell'inadempimento, Padova: Cedam, 2016.

BESSONE, Darcy. Do contrato: teoria geral, São Paulo: Editora Saraiva, 1997.

BESSONE, Mario. Adempimento e rischio contrattuale, Milano: Dott. A. Giuffrè Editore, 1975.

BETTI, Emilio. Teoria General de las Obligaciones, tomos I e II, trad. José Luis de los Mozos, Madrid: Editorial Revista de Derecho Privado, s/d.

------- Teoria generale del negozio giuridico, Collana: Università di Camerino, Napoli: Edizioni Scientifiche Italiane, 2002.

BEVILÁQUA, Clóvis. Teoria Geral do Direito Civil, RED Livros, edição, 1999.

Código Civil dos Estados Unidos do Brasil Commentado, vol. IV, $5^{\mathrm{a}}$ edição, Rio de Janeiro, Francisco Alves, 1938.

BIANCA, Cesare Massimo. La nozione di buona fede quale regola di comportamento contrattuale, artigo contido na Rivista di Diritto Civile, Padova: Cedam-Casa Editrice Dott. Antonio Milani, 1983.

(a cura di). La condizzioni generali di contratto, vols. I e II, Milano: Dott. A. Giuffrè Editore, 1979. 
BITTAR, Carlos Alberto et al. Os contratos de adesão e o controle de cláusulas abusivas, Editora Saraiva, São Paulo, 1991.

BITTAR Eduardo C. B.; e ALMEIDA, Guilherme Assis de. Curso de Filosofia do Direito, $9^{a}$ edição, São Paulo: Editora Atlas, 2011.

BONFANTE, Pietro. Istituzioni di Diritto Romano, $10^{\mathrm{a}}$ edizione, Torino: G. Giappichelli, 1946.

BOROWSKI, Martin, A estrutura dos direitos fundamentais sociais na lei fundamental da Alemanha, in TOLEDO, Cláudia (org.), Direitos sociais em debate, Elsevier, Rio de Janeiro, pp. 15-48, 2013.

BORRICAND, Jean. La clause résolutoire expresse dans les contrats, in Revue Trimestrielle de Droit Civil, Paris: Librairie Recueil Sirey, tomo 55, pp. 433-470, 1957.

BORRIONE, Marco. La risoluzione per inadempimento, Enciclopedia, collana diretta da Paolo Cendon, Padova: Casa Editrice Dott. Antonio Milani, 2004.

BRANCA, Giuseppe. Istituzioni di Diritto Privato, $2^{\mathrm{a}}$ edizione, Bologna: Dott. Cesare Zuffi-Editore, 1956.

BUCKLEY, F. H. The Fall and Rise of Freedom of Contract, Duke University Press, Durham and London, 1999.

BURTON, Steven J. Breach of contract and the common law duty to perform in good faith, Harvard Law Review, vol. 94, pp. 364-404, 1980/1981.

BUSSATA, Eduardo Luiz. Resolução dos Contratos e teoria do Adimplemento substancial. Coleção Prof. Agostinho Alvim, $2^{a}$ edição, São Paulo: Editora Saraiva, 2008. 
CANARIS, Claus-Wilhelm. Pensamento sistemático e conceito de sistema na ciência do direito. Trad. A. Menezes de Cordeiro. $2^{\mathrm{a}}$ ed., Lisboa: Fundação Calouste Gulbenkian, 1996.

La riforma del diritto tedesco delle obbligazioni, trad.: Marcello Farneti e Sonja Haberl, in: I quaderni della Rivista di Diritto Civile, Coord.: Giovanni de Cristofaro, Padova: Cedam, v. 3, 2003.

------- A liberdade e a justiça contratual na 'sociedade de direito privado', in A. Pinto Monteiro (coord.), Contratos: actualidade e evolução, Porto: Universidade Católica Portuguesa, p. 49/66, 1997.

CANNATA, Carlo Augusto. L'inadempimento delle obbligazioni, Padova: Cedam, 2008 .

CANOTILHO, J. J. Gomes. Direito Constitucional e Teoria da Constituição, $4^{\mathrm{a}}$ edição, Coimbra: Almedina. 1999.

CANTOS, Fernández. La resolución de los contratos por causa de incumplimiento (Requisitos necesarios para la aplicación del artículo 1124), in Revista General de Legislación y Jurisprudencia, pp. 49-50, 1960.

CAPITANT, Henri. De la cause des obligations, troisième édition, Paris: Librairie Dalloz, 1927.

CARBONNIER, Jean. Derecho Civil, tomo II, vol. II, Barcelona: Bosch, Casa Editorial, 1971.

------- Contrats spéciaux, in Revue Trimestrielle de Droit Civil, Paris: Librairie Recueil Sirey, pp. 369-378, 1950.

CARDILLI, Ricardo. "Vir bonus" e "bona fides", in Revista de Direito Civil Contemporâneo, nº 2, vol. 3, São Paulo: Ed. RT, pp. 267-288, abr.-jun. 2015. 
CARDOSO, Luiz Philipe Tavares de Azevedo. O Inadimplemento Antecipado do Contrato no Direito Civil Brasileiro, tese de doutorado defendida na Faculdade de Direito da USP, São Paulo, 2014.

CASSIN, René. Réflexions sur la résolution judiciaire du contrat pour inexécution, in Revue Trimestrielle de Droit Civil, Paris: Librairie Recueil Sirey, pp. 159-180, 1945.

------ De l'exception tiree de l'inexécution dans les rapports synallagmatiques, in Revue Trimestrielle de Droit Civil, Paris: Librairie Recueil Sirey, 1914.

CASTRO Y BRAVO, Federico de. Las condiciones generales de los contratos y la eficacia de las Leyes, Madrid: Editorial Cívitas, 1987.

CHIRELSTEIN, Marvin A. Concepts and Case Analysis in the Law of Contracts. Second edition, University Textbook Series, Westbury, New York: The Foundation Press, 1993.

CHESHIRE AND FIFOOTS. Cases on the Law of Contracts, Butterworths, London, 1977.

COLLURA, Giorgio. Importanza dell'inadempimento e teoria del contratto, Milano: Dott. Giuffrè, 1992.

CONTURSI-LISI, Lycia Gardani. Sulla risoluzione per inadempimento dell'onere, in Rivista di Diritto Civile, Padova: Cedam, anno XXIII, parte prima, pp. 241-269, 1977.

COUTO E SILVA, Clóvis Veríssimo do. Da obrigação como processo, São Paulo: Editora J. Bushatsky, 1976.

Princípio da boa-fé no Direito Brasileiro e Português, in Estudos de Direito Civil Brasileiro e Português, São Paulo: Editora Revista dos Tribunais, 1980. 
CRISTÓBAL MONTES, Ángel. La mora del deudor em la resolución contractual por incuplimiento, in Revista de Derecho Privado, pp. 91-128, 1985.

CROME. De la cause des obligations, Paris, 1924.

CRUZ, Sebastião da Costa. Da "solutio": terminologia, conceito e características, e análise de vários institutos afins, tese da Faculdade de Direito de Coimbra, Portugal, 1962.

CUBEDDU, M. Giovanna. L'importanza dell'inadempimento, Giappichelli, 1995.

CUNHA, Raphael Augusto. $O$ inadimplmento na nova teoria contratual: $o$ Inadimplemento Antecipado do Contrato, dissertação de mestrado defendida na Faculdade de Direito da USP, São Paulo, 2015.

CUNNINGHAM, Lawrence A. Cardozo and Posner: a study in contracts, Willian \& Mary Law Review, 36 Wm. \& Mary L rev. 1379, pp. 2 e 26, Spring, 1995.

DANTAS JÚNIOR, Aldemiro Rezende. A Teoria dos Atos Próprios: elementos de identificação e cotejo com institutos assemelhados, tese de doutorado pela Pontifícia Universidade Católica de São Paulo, São Paulo, 2006.

DAVID, René. Les Contrats en Droit Anglais, Librairie Générale de Droit et de Jurisprudence, Paris, 1973.

------ O Direito Inglês, São Paulo: Editora Martins Fontes, 2000.

DAVIES, F. R. Contract, Third edition, Sweet e Maxwell, London, 1977.

DE LA GRANGE, Klitsche. Risoluzione per inadempimento e potestà del giudice, Rivista di Diritto Civile, vol. I, p. 28, 1964. 
DELL'AQUILA, Enrico. La ratio della risoluzione del contratto per inadempimento, in Rivista di Diritto Civile, Padova: Cedam, anno XXIX, parte seconda, pp. 836-864, novembro-dezembro de 1983.

------- Resolución de los contratos bilaterales por incumplimiento de una de las partes, Salamanca: Universidad de Salamanca, 1979.

DE MARTINI, Angelo. Eccessiva onerosita nell'esecuzione dei contratti, Milano: Dott. A. Giuffrè, 1950.

DEMOGUE, René. Obligations et Contrats spéciaux, in Revue Trimestrielle de Droit Civil, Paris: Librairie Recueil Sirey, pp. 608-646, 1937.

Obligations et Contrats spéciaux, in Revue Trimestrielle de Droit Civil, Paris: Librairie Recueil Sirey, pp. 115-144, 1914.

DERIU, Luciano. Clausola risolutiva espressa e gravità dell'inadempimento, in Rivista Trimestrale di Diritto e Procedura Civile, Milano: Dott. A. Giuffrè Editore, anno XVIII, numero 1, marzo, pp. 421-425, 1964.

DERNBURG, Arrigo. Diritto delle Obbligazioni, traduzioni per Francesco Bernardino Cicala, Torino: Fratelli Bocca, Editori, 1903.

DE SIMONE, Mario. Il contratto com prestazioni corrispettive, in Rivista Trimestrale de Diritto e Procedura Civile, Milano: Dott. A. Giuffrè Editore, anno II, pp. 23-50, 1948.

DIDIER JR., Fredie. Notas sobre a aplicação da teoria do adimplemento substancial no Direito Processual Civil brasileiro, in Revista da ESMAPE, Recife, v. 14, $\mathrm{n}^{\circ} 29$, jan/jun, pp. 179-184, 2009.

DIEZ-PICAZO, Luis. El retardo, la mora y la resolución de los contratos sinalagmaticos, Anuario de Derecho Civil, 1969. 
------- La doctrina de los propios actos, Barcelona: Bosch, 1963.

DOLINGER, Jacob. Direito Internacional Privado (parte geral), $2^{\mathrm{a}}$ edição, Rio de Janeiro: Editora Renovar, 1993.

DONNINI, José Rogério Ferraz. A concepção social do contrato. Disponível em: <http://www.gentevidaeconsumo.org.br/prof_convidados/rogerio/concepcao_social.htm >. Acesso em: $21 \mathrm{dez} .2006$.

DWORKIN, Ronald. Isaac Marks Memorial Lecture: Do Values Conflict? A hedgehog's approach, Arizona Law Review, nº 43, 2001.

------ Keynote address, in DU BOIS, Francois (ed.), The Practice of Integrity: Reflections on Ronald Dworkin and South African Law, Juta, Lansdowne, pp. 1-17, 2004.

Freedom's Law: The Moral Reading of the American Constitution, Cambridge: Harvard University Press, pp.1-43, 1996.

------ You cannot calculate human rights based on cost, Comment is free, The Guardian, 24.05.2006.

Rawls e a filosofia do Direito, in DWORKIN, Ronald, Justice in robes, Cambridge: Harvard University Press, 2006.

EBKE, Werner F. e STEINHAUER, Bettina M. The doctrine of good faith in german contract law, edited by FRIEDMANN, Daniel, and BEATSON, Jack. Good Faith and Fault in Contract Law, Oxford: Clarendon Paperbacks, pp. 171-190, 2002.

ESTACAILLE, Jorge Priore. Resolución de Contratos Civiles per Incumplimiento, tomo II, Amalio Fernandez, Montevideo, 1974. 
FARNSWORTH, Allan. Introdução ao sistema jurídico dos Estados Unidos, Rio de Janeiro: Editora Forense, 1963.

- Good Faith in Contract Performance, edited by FRIEDMANN, Daniel, and BEATSON, Jack. Good Faith and Fault in Contract Law, Oxford: Clarendon Paperbacks, pp. 153-170, 2002.

FERRAND, Frédérique. Droit Privé Allemand, Paris: Librairie Dalloz, 1997.

FERRAZ JUNIOR, Tercio Sampaio. Introdução ao Estudo do Direito - Técnica, Decisão, Dominação, $6^{a}$ edição, São Paulo: Editora Atlas, 2010.

FERREIRA, Antonio Carlos. A interpretação da doutrina do adimplemento substancial (partes 1 e 2), in Consultor Jurídico, nº 9, fev., 2015.

FERREIRA FILHO, Manoel Gonçalves. Princípios Fundamentais do Direito Constitucional, $2^{\mathrm{a}}$ edição, São Paulo: Editora Saraiva, 2010.

FERREIRA RUBIO, Delia Matilde. La buena fe: El principio general en el Derecho Civil, Madrid: Editorial Montecorvo, 1984.

FERRI, Luigi. L'Autonomia Privata, Milano: Dott. A. Giuffrè Editore, 1959.

FINNIS, John M. Natural Law and Legal Reasoning, in GEORGE, Robert P. (org.), Natural Law Theory: contemporary essays, Oxford University Press, Oxford, pp. 134157, 1992.

FONSECA, Arnoldo Medeiros da. Caso fortuito e teoria da imprevisão, $3^{\mathrm{a}}$ edição, Rio de Janeiro: Editora Forense, 1958.

FRADERA, Vera Maria Jacob de. O conceito de inadimplemento fundamental do contrato no art. 25 da lei internacional sobre vendas, da Convenção de Viena de 1980, in Revista da Faculdade de Direito do Rio Grande do Sul, Livr. Ad., vol. II, 1991. 
FRANÇA, Limongi. Princípios Gerais de Direito, São Paulo: Editora Revista dos Tribunais, 2010.

------- Hermenêutica Jurídica, São Paulo: Editora Saraiva, 1988.

FRANÇOIS, Clément. Présentation des articles 1224 à 1230 de la nouvelle soussection 4 "La résolution", La réforme du droit des contrats présentée par l'IEJ de Paris 1, https://iej.univ-paris1.fr/openaccess/reforme-contrats/titre3/stitre1/chap4/sect5/ssect4resolution/ [consulté le 22/10/2018].

GILISSEN, John. Introdução Histórica ao Direito, trad. de A. M. Hespanha e L. M. Macaísta Malheiros, Lisboa: Fundação Calouste Gulbenkian, 2001.

GILMORE, Grant. The death of contract, Ohio State University Press, Columbus, 1995.

GILSON, Bernard. Inexécution et Résolution en Droit Anglais, Paris: Librairie Générale de Droit et de Jurisprudence, 1969.

GIORGIANNI, Michelle. L'Inadempimento, Milano: Dott. A. Giuffrè Editore, 1959.

GODLEY, James. The Philosophical Origins of Modern Contract Doctrine, Oxford: Clarendon Law Series and Press, 1992.

GODOY, Cláudio Luiz Bueno de. Função social do contrato: os novos princípios contratuais, $4^{\text {a }}$ edição, São Paulo: Editora Saraiva, 2012.

GOGLIANO, Daisy. Tratativas pré-contratuais (bases para uma teoria), São Paulo: Quartier Latin do Brasil, 2013.

A função social do contrato (causa e motivo), in Revista da Faculdade de Direito da USP, v. 99, São Paulo, pp. 153-198, 2004. 
GOMES, Orlando. Contratos, 12a edição, Rio de Janeiro: Editora Forense, 1992.

Obrigações, 12a edição, Rio de Janeiro: Editora Forense, 1999.

Contrato de Adesão, São Paulo: Revista dos Tribunais, 1972.

Transformações gerais do Direito das Obrigações, $2^{\mathrm{a}}$ edição, São Paulo: Revista dos Tribunais, 1980.

GONZÁLEZ GONZÁLEZ, Aurora. La resolución como efecto del incumplimiento em las obligaciones bilaterales, pp. 50-72, 1987.

GORLA, Gino. Il Contratto - Corso di Diritto Privato svolto secondo il metodo compartivo e casistico, vols. I e II, Milano: Giuffrè Editore, 1954.

------ El Contrato - Problemas fundamentales tratados según el método comparativo y casuístico. Trad. José Ferrandis Vilella; Bosch, Barcelona: Casa Editorial, Urgel, 51 bis, 1959.

Intérêts et Problèmes de la Comparaison entre le Droit Continental et la Common Law, in Revue Internationale de Droit Comparé, Paris, janvier-mars, 1963.

------- La Causa nel Pensiero dei Giuristi di Common Law, in Rivista del Diritto Commerciale, Milano: Casa Editrice Dottor Francesco Vallardi, anno XLIX, parte prima, s/d.

GRASSO, Biagio. Saggi sull'eccezione d'inadempimento e la risoluzione del contratto, Napoli: Edizioni Scientifiche Italiane, 2000.

GROSSO, Giuseppe. Il sistema romano dei contratti, $3^{\mathrm{a}}$ edição, Torino: Giappichelli, 1963. 
HEINRICH, Carolyn J. The Performance of Performance Standards. Employment Research 18(2): 4-5, 2011, https://doi.org/ 10.17848/1075-8445.18(2)-2.

HOLMES Jr, Oliver Wendell. The Common Law, Third four printing, Boston: Little, Brown and Company, 1938.

HUCK, Hermes Marcelo. Sentença Estrangeira e Lex Mercatoria - horizontes e fronteiras do comércio internacional, São Paulo: Editora Saraiva, 1994.

IBÁÑEZ, Carlos Miguel. Resolución por incumplimiento, Buenos Aires: Astrea, 2003.

IMEL, Lawrence J. Substantial Compliance with the Contractors' State License Law: An Equitable Doctrine Producing Inequitable Results, 34 Loy. L.A. L. Rev. 1539 (2001), available at: https://digitalcommons.lmu.edu/llr/vol34/iss4/15.

IUDICA, Giovanni. Risoluzione per inadempimento, in Rivista di Diritto Civile, anno XXIX, parte seconda, Padova: Cedam, pp. 184-192, 1983.

JACKSON, Vicki. C. Constitutional Law in an Age of Proportionality, Yale L. J., $\mathrm{n}^{\circ}$ 124 [124 YALE L.J., 3094 (2015)].

JORDANO BAREA, Juan Bautista. Cumplimiento tardio y facultad resolutória tácita. Sentencia 9 junio 1950, in Anuario de Derecho Civil, pp. 305-310, 1951.

JOSSERAND, Louis. Derecho Civil, trad. de S. Cunchillos, t. II, Buenos Aires, 1950.

KASER, Max. Direito Privado Romano, tradução de Samuel Rodrigues e Ferdinand Hämmerle, Lisboa: Fundação Calouste Gulbenkian, 1999.

KLASS, Gregory. Interpretation and Construction in Contract Law, Georgetown University Law Center, gmk9@ law.georgetown.edu, 2018. 
KLATT, Matthias; MEISTER, Moritz. A proporcionalidade como princípio constitucional universal, Tradução de Philippe Seyfarth de Souza Porto, in Revista Publicum no 1, pp. 30-70, 2015.

LADEUR, Karl-Heinz; CAMPOS, Ricardo. Entre teorias e espantalhos - deturpações constitutivas na teoria dos princípios e novas abordagens, in CAMPOS, Ricardo (org.), Crítica da Ponderação, Método constitucional entre a dogmática jurídica e a teoria social - Ensaios traduzidos, São Paulo: Saraiva, pp. 97-132, 2016.

LARENZ, Karl. Derecho de Obligaciones. Tomo I e II., trad. de Jaime Santos Briz, Madrid: Editorial Revista de Derecho Privado, s/d.

----- Metodologia da Ciência do Direito. Trad. de José Lamego, $3^{\mathrm{a}}$ edição, Lisboa: Fundação Calouste Gulbenkian, 2001.

LEITE, Ana Paula Parra. Equilíbrio Contratual, tese de doutorado na FADUSP, São Paulo, 2013.

LEPELTIER, Eugéne. La résoluton judiciaire des contrats pour inexécution des obligations, Librairie Dalloz, 1934.

LONGHI, Maria Isabel Carvalho Sica. Inadimplemento Antecipado, dissertação de mestrado defendida na Faculdade de Direito da USP, São Paulo, 2014.

LOPEZ, Teresa Ancona. Exercício do direito e suas limitações: abuso de direito, São Paulo: Revista dos Tribunais, vol. 885, pp. 49-68, 2009.

MACIOCE, Francesco. Risoluzione del contratto e imputabilità dell'inadempimento, Napoli: Edizioni Scientifiche Italiane, 1988.

MAJOR, W. T. Cases in Contract Law, London: Macdonald e Evans Ltd, 1972.

------- The Law of Contract, London: Macdonald e Evans Ltd, 1965. 
MAMAN, Jeannette Antonios. Fenomenologia Existencial do Direito, $2^{\text {a }}$ ed. São Paulo: Editora Quartéis Lacem, 2003.

MARESCA, Giovanni. Impossibilità della restitutio in integrum e risolubilità, rescindibilità, annullabilità del contratto, in Rivista di Diritto Civile, Padova: Cedam, anno XXIII, parte seconda, pp.78-93, 1977.

MARKESINIS, Basil S.; UNBERATH, Hannes; e JOHNSTON, Angus. The German Law of Contract, second edition, Oxford and Portland, pp. 379-491, 2006.

MARQUES, Claudia Lima. Boa-fé nos serviços bancários, financeiros, de crédito e securitário e o código de defesa do consumidor: informação, cooperação e renegociação?, Revista de Direito do Consumidor - RDC 43/2002, jul.-set./2002.

MARTINS-COSTA, Judith. Boa-fé no Direito Privado, São Paulo: Editora Revista dos Tribunais, 2001.

A Teoria da Causa em Perspectiva Comparativista: a Causa no Sistema Civil Francês e no Sistema Civil Brasileiro, in Revista AJURIS, $n^{\circ}$ 45, Porto Alegre-RS, novembro de 1989.

MARTINS, Lucas Gaspar de Oliveira. Contornos do inadimplemento absoluto, da mora e do adimplemento substancial: principais características e distinções, tese de mestrado defendida na Pontifícia Universidade Católica de São Paulo PUC-SP, São Paulo, 2008.

MAZEAUD, Henri, Léon et Jean. Leçons de Droit Civil, t. II, Paris, 1956; ou Lecciones de Derecho Civil, Ediciones Jurídicas Europa-America, Buenos Aires, 1960.

MCKINNEY, F. C. Substantial Performance in Building and Construction Contracts, 28 Bench and Bar 59, 1912. 
MELLO, Marcos Bernardes de. Teoria do fato jurídico (plano de existência), $9^{\mathrm{a}}$ edição, São Paulo: Editora Saraiva, 1999.

MELLO, Renata Rapold. O Princípio da boa-fé objetiva. Disponível em: < http://www.juspodivm.com.br/i/a/\{EDFB6304-BBB3-4B77-B7F5-

4E7EB99DC4B4\}_Artigo\%20-\%200\%20Princ\%C3\%ADpio\%20da\%20Boa-

fe\%C3\%A9\%20objetiva.doc>. Acesso em: 07 dez. 2007.

MENEZES CORDEIRO, António Manuel da Rocha. Da boa fé no Direito Civil, dissertação de doutoramento em ciências jurídicas na Faculdade de Direito da Universidade de Lisboa, $4^{\mathrm{a}}$ Reimpresão. Coleção Teses, Coimbra: Almedina, 2011.

------ Tratado de Direito Civil: Direito das Obrigações, vol. IX, $3^{\text {a }}$ edição, Coimbra: Almedina.

MEORO, Clemente. La resolución de los contratos por incumplimiento (Estúdio comparativo, doctrinal y jurisprudencial del derecho inglês y del derecho español), Tirant lo Blanch, Valencia, pp. 188-198, 1992.

MESSINEO, Francesco. I Contratti in generi, Trattato di Diritto Civile e Commerciale, $4^{\mathrm{a}}$ edição, Milano: Giuffrè Editore, 1981.

MIQUEL, Juan Luis. Resolución de los contratos por incumplimiento, Buenos Aires: Depalma, 1986.

MIRABELLI, Giuseppe. Eccessiva onerosità e inadempimento, in Rivista del Diritto Commerciale, Milano: Casa Editrice Dottor Francesco Vallardi, anno LI, parte seconda, pp. 84-93, 1953.

La rescissione del contratto, Napoli: Casa Editrice Dott. Eugenio Jovene, 1962.

MIRANDA, Custódio da Piedade U. Contrato de adesão, tese de livre docência na Universidade de São Paulo, São Paulo, 2000. 
MÖLLER, Kai. Balancing and the Structure of Constitutional Rights, International Journal of Constitutional Law, vol. 5, Issue 3, pp. 453-468, 2007. (Disponível em: http://ssrn.com/abstract=1156228 ou http://dx.doi.org/10.1093/icon/mom023).

MONTÉS PENADÉS, Vicente Luis. Comentário a los artículos 1113 a 1124, en AA. VV. Artículos 1088 a 1124 del Código Civil, en Comentarios al Código Civil y Compilaciones Forales, dirigidos por Manuel Albaladejo, tomo XV, vol. 1º Madrid: Edersa, pp. 1177-1181, 1989.

MORELLO, Augusto M. Ineficacia y frustración del contrato, Libreria Editora Platense Abeledo-Perret, 1975.

MOSCO, Luigi. La risoluzione del contratto per inadempimento, Napoli: Casa Editrice Dott. Eugenio Jovene, 1950.

MOSSET ITURRASPE, Jorge. Justicia contractual, Buenos Aires: Ediar, 1978.

MOTA PINTO, Carlos Alberto. Teoria Geral do Direito Civil, $3^{\text {a }}$ edição, Coimbra: Coimbra Editora, 1990.

MOZOS, José Luis de los. La buena fe en el titulo preliminar del Codigo Civil, in Derecho Civil (método, sistemas y categorias jurídicas), primera edición, Madrid: Editorial Civitas, pp. 211-237, 1988.

MULLIGAN, William Hughes. Essentials of Insurance Law, 26 Fordham L. Rev. 734 (1957), available at: http://ir.lawnet.fordham.edu/flr/vol26/iss4/9.

MUNOZ, Maria Paula Costa Bertran. Justiça e contrato - entre comutar e distribuir, tese de doutorado na FADUSP, orientada por Ronaldo Porto Macedo Júnior, São Paulo, 2010 . 
MUTARELLI, Adolfo. Per il superamento della colpa nell'ipotesi di clausola risolutiva espressa, in Rivista di Diritto Civile, Padova: Casa Editrice Dott. Antonio Milani, anno XXIV, parte seconda, pp. 252-268, 1978.

NANNI, Luca; COSTANZA, Maria; CARNEVALI, Ugo. Della risoluzione per inadempimento, tomo I, 2, Commentario del Codice Civile Scialoja-Branca - a cura di Francesco Galgano, Bologna: Zanichelli Editore e Roma: Soc. Ed. del Foro Italiano, 2007.

NEHME, Jorge Elias. Boa-fé contratual no Novo Código Civil. Intelligentia Juridica. Recife, ano IV, n.64, out. 2006.

NERILO, Lucíola F. L. A responsabilidade civil pelo descumprimento da cláusula geral de boa-fé nos contratos, Revista dos Tribunais, ano 96, volume 866, dezembro de 2007.

NORONHA, Fernando. Contratos de Consumo, Padronizados e de Adesão. In. LIMA MARQUES, Claudia; MIRAGEM, Bruno. (coordenadores). Direito do Consumidor. São Paulo: Editora Revista dos Tribunais (coleção doutrinas essenciais; v. 4), 2011.

OLSON, Robert D. Substantial Performance under the Uniform Commercial Code, 16 Wyo. L.J. 178 (1962), available at: http://repository.uwyo.edu/wlj/vol16/iss2/19.

OERTMANN. Rechts der Sculdverhältnisse, 1. Abteilung, Berlin, 1928.

PANTALEÓN, Fernando. El sistema de responsabilidad contractual (Materiales para um debate), in Anuario de Derecho Civil, pp. 1020 e ss., 1991.

Resolución por incumplimiento e indemnización, in Anuario de Derecho Civil, pp. 1143-1168, 1999.

PATTERSON, Edwin W. The apportionment of business risks through legal devices, in Columbia Law Review, 1924. 
PAULY, Clemens. The Concept of Fundamental Breach as an International Principle to Create Uniformity of Commercial Law. In: Journal of Law and Commerce, vol. 19, pp. 221-243, Spring 2000.

PEREIRA, Caio Mário da Silva. Instituições de Direito Civil - Teoria Geral das Obrigações, vol. II, 25ª edição, Rio de Janeiro: Editora Forense-GEN, 2013.

PERILLO, Joseph M. Unidroit Principles of International Commercial Contracts: The Black Letter Text and a Review, 63 Fordham L. Rev. 281 (1994), Available at: http://ir.lawnet.fordham.edu/flr/vol63/iss2/1.

PERLINGIERI, Pìetro. Il fenomeno dell'estinzione nelle obbligazioni, Napoli: Jovene, 1971.

PERSICO, Giovanni. L'Eccezione d'inadempimento, Milano: Dott. A. Giuffrè Editore, 1955.

PICARD, Maurice, et PRUDHOMME, André. De la résolution judiciaire pour inexécution des obligations, in Revue Trimestrielle de Droit Civil, t. II, pp. 61-109, 1912.

PLUCKNETT, Theodore F. T. A Concise History of the Common Law, Fifth edition, London: Butterworth e Co. Publishers Ltd, 1956.

POSCHER, Ralf. Teoria de um Fantasma - A Malsucedida busca da Teoria dos Princípios pelo seu Objeto, in CAMPOS, Ricardo (org.), Crítica da Ponderação, Método constitucional entre a dogmática jurídica e a teoria social - Ensaios traduzidos, São Paulo: Editora Saraiva, pp. 63-96, 2016.

PONTES DE MIRANDA, Francisco Cavalcanti. Tratado de Direito Privado, vários volumes, Rio de Janeiro: Borsoi, 1970. 
PROENÇA, José Carlos Brandão. A Resolução do Contrato no Direito Civil, in Boletim da Faculdade de Direito da Universidade de Coimbra, suplemento XXII, 1975.

A resolução do contrato no Direito Civil - do enquadramento e do regime, Coimbra Editora, 2006.

RAMELLA, Anteo E. La resolución por incumplimiento - pacto comisorio y mora en los derechos civil y comercial, Buenos Aires: Editorial Astrea, 1975.

RANOUIL, Véronique. L'Autonomie de la Volonté, $1^{\mathrm{a}}$ ed., Paris: Presses Universitaires de France, 1980.

RAWLS, John. The Basic Liberties and Their Priority, en: Id., The Tanner Lectures on Human Values, Salt Lake City, Conferência VIII, in Liberalismo Político, Editora Ática, pp. 344-430, 1983.

REALE, Miguel. O projeto do novo Código Civil, São Paulo: Editora Saraiva, 1986.

------- História do novo Código Civil, Coleção Biblioteca de Direito Civil, vol. 1, São Paulo: Editora Revista dos Tribunais, 2005.

------ A boa-fé no Código Civil, artigo na internet, in www.miguelreale.com.br/artigos/boafe, 16.08.2003.

RIBEIRO, Joaquim de Sousa. O problema do contrato - As cláusulas contratuais gerais e o princípio da liberdade contratual, Coimbra: Livraria Almedina, 1999.

RICCIUTO, Vincenzo. Il recente orientamento della Cassassione sui criteri de valutazione dell'importanza dell'inadempimento, in Rivista del Diritto Commerciale, Milano: Casa Editrice Dr. Francesco Vallardi, anno LXXXV, settembre-dicembre, pp. 454-464, 1987. 
ROMEO, Christian. I Presupposti sostanziali della fomanda di adempimento, Università degli Studi di Milano, Milano: Dott. A. Giuffré Editore, 2008.

ROPPO, Enzo. O Contrato, trad. de Ana Coimbra e M. Januário C. Gomes, Coimbra: Editora Almedina, 1988.

ROPPO, Vincenzo. Il contratto del Duemila, $3^{\mathrm{a}}$ edizione, Torino: G. Giappichelli Editore, 2011.

ROSSELlO, C. Carlo. Sull'onere del creditore di ridurre le conseguenze dell'inadempimento, in Rivista Trimestrale di Diritto e Procedura Civile, Milano, anno 37, vols. 3-4, pp. 1158-1184, 1983.

ROSSETTI, Marco. La risoluzione per inadempimento, Pratica Giuridica, Giurisprudenza e Dottrina, Seconda serie diretta da O. Fanelli, Milano: Dott. A. Giuffrè Editore, 2012.

ROWLEY, Keith A. Contract Construction and Interpretation: From the Four Corners to Parol Evidence (and Everything in Between), University of Nevada, Las Vegas William S. Boyd School of Law, Chicago-Kent Law Review, Scholarly Works, Paper $554,1999$.

RUBINO, Domenico. Costituzione in mora e risoluzione per inadempimento, in Rivista del Diritto Commerciale, Milano: Casa Editrice Dottor Francesco Vallardi, anno XLV, gruppo 4, ns 1 a 3, gennaio-marzo, pp. 53-67, 1947.

SACCO, Rodolfo e DE NOVA, Giogio. Il Contratto, nelle serie Trattato di Diritto Privato, $3^{\text {a }}$ ed., Torino: UTET, pp. 509-524, 2004.

SALEILLES, Raymond. De la declaration de volonté, Paris: F. Pichon, 1901.

SAMPAIO, Paulo Sérgio. Modelos de proteção do equilíbrio contratual: comparações franco-brasileiras, tese de doutorado na FADUSP, São Paulo, 2013. 
SANZ, Vicente Espert. La Frustración del Fin del Contrato. Madrid: Editorial Tecnos, 1968.

SATTA, Salvatore. Commentario al Codice di Procedura Civile e Diritto Processuale Civile, Milano: Giuffré, 1971.

SCAFF, Fernando Campos. As Novas Figuras Contratuais e a Autonomia da Vontade, in Revista da Faculdade de Direito da Universidade de São Paulo, São Paulo, 1996.

SÉROUSSI, Roland. Introdução ao Direito inglês e norte-americano, trad. Renata Maria Parreira Cordeiro, São Paulo: Landy Editora, 2006.

SCHIMPERNA, Pamela. Importanza dell'inadempimento nella risoluzione del contratto, Giustizia Civile, Milano: Giuffrè, 1995.

SCHREIBER, Anderson. A boa-fé objetiva e o adimplemento substancial, in Direito Contratual - temas atuais. HIRONAKA, Giselda; TARTUCE, Flávio, Coord. São Paulo: Método, 2008.

------ A tríplice transformação do adimplemento. Adimplemento substancial, inadimplemento antecipado e outras figuras. Revista Trimestral de Direito Civil RTDC, ano 8, v. 32, p. 3-37, out./dez., 2007.

SHIMEL, Sidney. The substantial performance of building contracts in Illinois. Chicago-Kent Law Review, Chicago, v. 20, nº 2, pp. 142-170, mar. 1942.

SICCHIERO, Gianluca. La risoluzione per inadempimento - Artt. 1453-1459, Il Codice Civile Commentario, fondato da Piero Schlesinger, diretto da Francesco D. Busnelli, Milano: Dott. A. Giuffrè Editore, pp. 539-589, 2007. 
SILVA, Alexandre Stagni Viana e. Tutela externa do crédito: uma análise da oponibilidade do contrato perante terceiros, dissertação de mestrado na FADUSP, São Paulo, 2016.

SILVA, Jorge Cesa Ferreira da. A boa-fé e a violação positiva do contrato, Rio de Janeiro: Editora Renovar, 2002.

SILVA, Pedro Gonzaga de Oliveira Carvalho e. Aplicação da teoria do adimplemento substancial no direito privado brasileiro, dissertação de mestrado defendida na Universidade de São Paulo, orientado pela Profa. Titular Dra. Teresa Ancona Lopez, São Paulo, 2016.

SILVA, Vivien Lys Porto Ferreira da. Adimplemento Substancial. Dissertação de mestrado defendida na Faculdade de Direito da Pontifícia Universidade Católica de São Paulo, orientada pelo Prof. Dr. José Rogério Donnini, São Paulo, 2006.

SMITH, Michael J. Comment, Contractor Licensing in the Construction Industry: Substantial Compliance Doctrine Prevents Egregious Results, 28 Santa Clara L. Rev. 143 (1988), available at: http://digitalcommons.law.scu.edu/lawreview/vol28/iss1/6.

SOUZA, Carlos Fernando Mathias de. A boa-fé no Direito Civil brasileiro e no português. Intelligentia Juridica, Recife, ano IV, $\mathrm{n}^{\circ}$ 64, out. 2006. Disponível em: $\langle$ http://www.intelligentiajuridica.com.br/v3/artigo_visualizar.php?id=858 $>$. Acesso em: 26 dez. 2006.

SPALLAROSSA, M. Rosa. Importanza dell'inadempimento e risoluzione del Contratto, in Rivista di Diritto Civile, Padova: Cedam, anno XVIII, parte seconda, $\mathrm{n}^{\mathbf{0}} 3$, pp. 452-480, 1972.

STANISLAS, Guy. Le Droit de résolution dans le contrat de vente: sanction de l'inexécution des obligations contractuelles, Genève: Georg Librairie de l'Université, 1979. 
STANNARD, John E. Delay in the performance of contractual obligations, UK: Oxford University Press, 2007.

STAUDINGER-WERNER. Kommentar sum Bürgerliches Gesetzbuch, vol. II, Schuldverhältnisse, Munchen, 1930.

STIGLITZ, Ruben S. Contratos - Teoria Geral, Buenos Aires: Ediciones De Palma, 1990.

STRENGER, Irineu. Direito Internacional Privado, vol. 1, parte geral, $2^{\mathrm{a}}$ edição, São Paulo: Editora Revista dos Tribunais, 1991.

TALAMANCA, Mario. Istituzioni di Diritto Romano, Milano: Dott. A. Giuffrè Editore, 1990.

TARTAGLIA, Paolo. Dichiarazione di risoluzione del contratto per fatti imputabile alla controparte e inadempimento prima del termine, in Rivista di Diritto Civile, Padova: Cedam, anno XXIII, parte seconda, pp. 20-29, 1977.

TARTUCE, Flávio. Teoria do adimplemento substancial na doutrina e na jurisprudência, 02.04.2016, disponível em http://www.cartaforense.com.br/artigos/teoria-do-adimplemento-substancial... acesso em 04 mar 2016.

TEPEDINO, Gustavo. Temas de Direito Civil, $3^{\mathrm{a}}$ edição, Rio de Janeiro: Editora Renovar, 2004.

THEODORO JR., Humberto. O contrato e sua função social, $3^{\mathrm{a}}$ edição, Rio de Janeiro: Editora Forense, 2008.

TOMASETTI JÚNIOR, Alcides. As relações de consumo em sentido amplo na dogmática das obrigações e dos contratos, in Revista do Direito do Consumidor $\mathrm{n}^{\circ} 13$, pp. $12-17$, s/d. 
------- Execução do Contrato Preliminar. Tese de doutorado defendida na FDUSP, São Paulo, 1982.

Abuso de poder econômico e abuso de poder contratual. Revista dos Tribunais, v. 715, pp. 87-107, 1995.

TOMASEVICIUS FILHO, Eduardo. A função social do contrato: conceito e critérios de aplicação. Revista de Informação Legislativa, Brasília, v. 42, nº 168, pp. 197-213, out./dez., 2005.

------- Uma década de função social do contrato: análise da doutrina e da jurisprudência brasileiras. São Paulo: Revista dos Tribunais, v. 103, nº 940, pp.49-85. fev. 2015.

TRABUCCHI, Alberto. Istituzioni di Diritto Civile, 44 ed., Padova: Casa Editrice Dott. Antonio Milani, 2009.

TREITEL, G. H. The Law of Contract, $6^{\mathrm{a}}$ edição, London: London Stevens \& Sons, 1983.

Alternatives and frustration, article in Good Faith and Fault in Contract Law, Oxford: Clarendon Paperbacks, pp. 377-396, 2002.

TRIMARCHI, Pietro. Il Contratto: inadempimento e rimedi, Milano: Dott. A. Giuffrè Editore, 2010.

TRINDADE, Antônio Augusto Cançado. Princípios do Direito Internacional Contemporâneo, Brasília-DF: Editora Universidade de Brasília, 1981.

TSAKYRAKIS, Stavros. Proportionality: An Assault on Human Rights, Jean Monnet Working Papers, $\mathrm{n}^{\circ}$ 9, 2008 (32 páginas); (também em: International Journal of Constitutional Law, $\mathrm{n}^{\circ}$ 7, 2009). 
TURCO, Claudio. L'imputabilità e l'importanza dell'inadempimento nella clausola risolutiva, Giappichelli, 1997.

UDA, Giovanni Maria. Integrazione del Contratto, Solidarietá Sociale e Corrispettività delle Prestazione, in Rivista del Diritto Commerciale, Milano: Casa Editrice Dottor Francesco Vallardi, gr. $4^{\circ}$, n$^{\circ}$ 5-6, maio-junho de 1990.

------ La buena fede nell'esecuzione del contrato, Studi di Diritto Privato 18, Torino: G. Giappichelli, 2004.

VARELA, João de Matos Antunes. Das obrigações em geral, tomo II, $7^{\text {a }}$ edição, Coimbra: Almedina, s.d.

VILLELLA, Aquila. Sull'importanza dell'inadempimento nella clausola risolutiva espressa, Collano Università, Rubberttino Editore, 2013.

VILLEY, Michel. Direito Romano, tradução de Fernando Couto, Porto: Resjuridica, Portugal, s.d.

VITUCCI, Paolo. Ogni ritardo sarà cosiderato di scarsa importanza (ipotesi sul patto di evitanda risoluzione), in Rivista di Diritto Civile, Padova: Cedam, ano XXXIV, $\mathrm{n}^{\circ} 5$, pp. 577-583, settembre-ottobre, 1988.

VON TUHR, Andreas. Tratado de las Obligaciones, Madrid: Editorial Reus S. A., 1934.

Derecho Civil, Buenos Aires: Editorial De Palma, 1948.

WIEACKER, Franz. El Principio General de la Buena Fe, Madrid: Editorial Civitas, 1977. 
WILLISTON, Samuel. Treatise on the Law of Contracts, Third Edition by Walter H. E. Jaeger, vols. 1 and 2, Mount Kisco, N.Y.: Baker, Voorhis and Co. 1959. Pp. xxii, 826; pp. xv, 1095, available at: http://repository.uwyo.edu/wlj/vol16/iss2/19.

WOLFF, Max J. Substantial Performance of Contracts in New York, 16 Corn. L. Q. 180 (1931); note (1931) 31 Col. L. Rev. 307, available at: http://scholarship.law.cornell.edu/clr/vol16/iss2/2.

ZANA, Mario. La regola della buena fede nell'eccezione di inadempimento, in Rivista di Diritto e Procedura Civile, Milano: Dott. A. Giufrrè Editore, anno XXVI, no 3 , settembre, 1972 .

ZANETTI, Cristiano de Sousa. Direito Contratual Contemporâneo - a liberdade contratual e sua fragmentação, Editora Método, São Paulo, 2008.

------- Inadimplemento Antecipado da Obrigação Contratual, capítulo contido in Arbitragem e Comércio Internacional - estudos em homenagem a Luiz Olavo Baptista, (coords.: AMARAL JÚNIOR, Alberto do; BASSO, Maristela; e CELLI JUNIOR, Umberto), São Paulo: Quartier Latin, pp. 311-332, 2013. 


\begin{abstract}
ANEXOS
Apresentam-se aqui decisões, acórdãos, cases, para atualização do tema.

Apelação cível nº 588016147, 03.04.1988

Relator Ruy Rosado der Aguiar Júnior, TJRS.

Apelação cível no 588016147, Tribunal de Justiça do RS, Quinta Câmara Cível, Desembargador relator: Ruy Rosado de Aguiar Júnior.

Ementa: CONTRATO. COMPRA E VENDA. RESOLUÇÃO. DESFEITOS NA CONSTRUÇÃO. Se os defeitos apresentados pelo imóvel não o tornam inabitáveis e podem ser reparados, não se decreta a resolução do contrato (art. 1092, parágrafo único do C.C.), mas defere-se ao comprador indenização que... Ver íntegra da ementa garante a sanação dos vícios de construção (art. 1056 do C.C.). Apelo provido em parte. (Apelação Cível No 588016147, Quinta Câmara Cível, Tribunal de Justiça do RS, Relator: Ruy Rosado de Aguiar Júnior, Julgado em 03/04/1988)... Revista de Jurisprudência: RJTJRS, V-133/343. Data de Julgamento: 03/04/1988.
\end{abstract}

Apelação cível nº 589016534, 02.05.1989

Relator Ruy Rosado der Aguiar Júnior, TJRS.

Apelação Cível no 589016534, Tribunal de Justiça do RS, Quinta Câmara Cível, Desembargador relator: Ruy Rosado de Aguiar Júnior.

Ementa: CONTRATO. RESOLUÇÃO. ADIMPLEMENTO SUBSTANCIAL. 1. A construtora que demora na entrega do apartamento, criando com isso séria dificuldade para o comprador, não pode pretender a resolução do negócio, em prejuízo do comprador, apenas porque este não quis suportar sozinho...Ver íntegra da ementa os ônus da demora. 2. Improcedência também da ação consignatória proposta pelo 
comprador, que depositou quantias insuficientes. Porém, tendo ele cumprido substancialmente sua obrigação, o contrato deve ser mantido. (Apelação Cível $\mathrm{N}^{\circ}$ 589016534, Quinta Câmara Cível, Tribunal de Justiça do RS, Relator: Ruy Rosado de Aguiar Júnior, Julgado em 02/05/1989)... Assunto: 1. CONTRATO. RESOLUÇÃO. ADIMPLEMENTO SUBSTANCIAL. CONSTRUTOR. DEMORA NA ENTREGA DE OBRA (APARTAMENTO). RESOLUÇÃO DO NEGÓCIO. CONSIGNAÇÃO EM PAGAMENTO. OFERTA INSUFICIENTE. Revista de Jurisprudência: RJTJRS 145/219. JURISPRUDÊNCIA TJRS, C-CIVEIS, 1994, V-3, T-43, P-143-152. SSS. Data de Julgamento: 02/05/1989. 
RECURSO ESPECIAL No 712.173 - RS (2004/0179902-0)

$\begin{array}{ll}\text { RELATOR: } & \text { MINISTRO CARLOS ALBERTO MENEZES DIREITO } \\ \text { RECORRENTE: } & \text { AGROSETA S/A } \\ \text { ADVOGADOS: } & \text { MÁRCIO LOUZADA CARPENA E OUTROS } \\ & \text { JAQUELINE FRANCESCHETTI E OUTRO } \\ \text { RECORRIDO: } & \text { JAIR JOÃO VIDALETTI } \\ \text { ADVOGADO: } & \text { RITA PERONDI E OUTRO }\end{array}$

\section{EMENTA}

Quitação. Embargos de declaração: julgamento em mesa, ausência de pressupostos e afastamento da multa. Impropriedade dos dispositivos apontados diante da situação de fato. Atualização monetária. Dissídio.

1. Diante dos fatos indicados pelo acórdão, não descartados pela parte, não se pode dizer que os embargos tenham sido julgados em sessão diversa daquela prevista no Código de Processo Civil, sendo postos em mesa na sessão seguinte à distribuição ao Relator.

2. Afasta-se a existência da omissão quando a leitura dos acórdãos da apelação e dos declaratórios não deixa margem a nenhuma dúvida de que foram examinados todos os pontos de interesse para a causa e relevantes para o julgamento do Tribunal local.

3. Incabível é a multa do art. $\underline{538}$, parágrafo único, do Código de Processo Civil quando os embargos estão nos limites da Súmula nº 98 da Corte.

4. Não há falar em violação dos dispositivos sobre a quitação, no cenário dos autos, examinada a prova pericial e documental que mostrou efetuados os pagamentos e justa a recusa quanto à última prestação, assentando o acórdão, ainda, a prevalência do adimplemento substancial e da recusa da parte recorrente no cumprimento de sua obrigação de outorga da escritura, fundamentos que passaram ao largo do especial.

5. A prova dos autos deitou por terra, como posto no acórdão, a alegada manobra dolosa do réu para iludir funcionário da autora quanto à quitação. 
6. O dissídio não procede porquanto não guardam os paradigmas as mesmas bases fáticas dos autos.

7. Recurso especial conhecido e provido, em parte.

\section{ACÓRDÃO}

Vistos, relatados e discutidos os autos em que são partes as acima indicadas, acordam os Ministros da Terceira Turma do Superior Tribunal de Justiça, por unanimidade, conhecer em parte do recurso especial e, nessa parte, dar-lhe provimento, nos termos do voto do Sr. Ministro Relator. Os Srs. Ministros Nancy Andrighi, Castro Filho, Humberto Gomes de Barros e Ari Pargendler votaram com o Sr. Ministro Relator. Sustentou oralmente o Dr. Valternei Melo de Souza, pelo recorrente.

Brasília (DF), 17 de outubro de 2006 (data do julgamento).

\section{MINISTRO CARLOS ALBERTO MENEZES DIREITO}

Relator

\section{RECURSO ESPECIAL N 712.173 - RS (2004/0179902-0) RELATÓRIO}

\section{O EXMO. SR. MINISTRO CARLOS ALBERTO MENEZES DIREITO:}

Agroseta S.A. interpõe recurso especial, com fundamento nas alíneas a e c do permissivo constitucional, contra acórdão da Vigésima Câmara Cível do Tribunal de Justiça do Estado do Rio Grande do Sul, assim ementado:

"DECISAO QUE RECEBEU APELAÇO ADESIVA. RECURSO CABÍVEL. ART $\underline{523}, \underline{4^{\circ}}, \underline{C P C}$.

Em se tratando de decisão que recebeu apelação adesiva, o recurso adequado a impugná-la é o agravo de instrumento, já que nenhum interesse recursal se pode ver no agravo retido.

APELAÇO ADESIVA. AUSÊNCIA DE SUCUMBÊNCIA. TEMÁTICA ABRANGIDA PELO EFEITO DEVOLUTIVO DA APELACAO PRINCIPAL.

Não se pode conceber o manejo de recurso adesivo, quando a parte não sofreu derrota alguma em termos práticos, bem como a temática desfiada na irresignação subordinada está embutida na própria devolução trazida pelo recurso principal.

DOLO. CONFUSÃo QUANTO A PAGAMENTOS DE DOIS CONTRATOS. AUSÊNCIA DE TODA E QUALQUER PROVA. 
Não se pode aceitar a alegação da parte autora, quanto a ter ocorrido confusão, intencionalmente causada pelo réu, em relação a pagamentos de um dos dois contratos, aproveitados em duplicidade, diante da inteira falta de provas.

QUITAÇO SEM RESERVAS. DISPENSA DE CORREÇÃo MONETÁRIA. ENTREGA DOS TÍTULOS SOMADA A OUTROS INDÍCIOS. RESPEITO À BOAFÉ OBJETIVA.

É de se considerar como remitida a parcela da dívida correspondente à atualização monetária quando o credor procedeu à entrega dos títulos, havendo recebido, em alguns casos, adiantamento e, quanto a outros, manifestado, expressamente, tal dispensa.

\section{RETENÇA DA DERRADEIRA PARCELA. QUEBRA POSITIVA DO

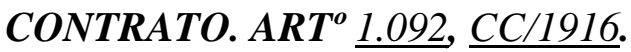

Quando o devedor assume conduta que se afigura incompatível com o cumprimento de dever acessório básico, há razão jurídica na conduta daquele que, tendo adimplido substancialmente o contrato, retém o pagamento da derradeira prestação" (fl. 2.182).

Opostos embargos de declaração (fls. 2.214 a 2.219 e 2.231 a 2.237), foram rejeitados (fls. 2.223 a 2.229 e 2.247 a 2.252), sendo que os segundos sofreram aplicação de multa de $1 \%$ sobre o valor da causa.

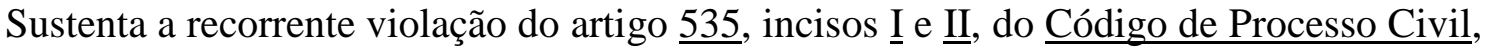
haja vista que não foram sanadas as omissões do julgado recorrido ainda que interpostos embargos declaratórios.

Assevera afronta aos artigos $\underline{537}$ e $\underline{552}$ do Código de Processo Civil e $5^{\circ}$, inciso LX, e $\underline{53}$, inciso IX, da Constituição Federal, pois "os embargos de declaração da apelação foram submetidos a julgamento em data outra (que não a próxima sessão), sem que tivessem, contudo, sido intimados os procuradores para acompanharem a sessão" (fl. 2.268).

Alega ofensa ao artigo $\underline{538}, \underline{1}^{\circ}$, do Código de Processo Civil, uma vez que os "embargos de declaração com notório propósito de prequestionamento não têm caráter protelatório" (fls. 2.272/2.273) e que "o manejo de tais embargos para trazer a prequestionamento matéria superveniente a propositura do recurso proposto anteriormente apresentou-se imprescindível, sob pena de não se poder levar essas questões, nascidas posteriormente, à apreciação desta Corte Superior" (fl. 2.273). 
Aduz contrariedade ao artigo $\underline{940}$ do Código Civil de 1916, levando em conta "o Tribunal "a quo" considerou quitadas parcelas desprovidas da quitação" (fl. 2.289) a que se refere o dispositivo legal citado, ampliando a quitação "ao ponto de abranger a totalidade dos valores dos contratos referentes aos negócios jurídicos subjacentes" (fl. 2.289).

Argúi negativa de vigência dos artigos $\underline{959}$, inciso $\underline{\mathrm{I}} \underline{960}, \underline{973}$, inciso $\underline{\mathrm{V}}$, e $\underline{974}$ do Código Civil de 1.916, tendo em vista que "o recorrido estava constituído em mora e não foram atendidos os dispositivos legais ensejadores de sua liberação" (fl. 2.292). Argumenta que "a outorga das escrituras somente seria devida por ocasião do pagamento da derradeira parcela, O QUE NÃO OCORREU, impossível admitir-se as teorias da quebra positiva do contrato elou adimplemento substancial para afastar a mora do recorrido, sem ao menos verificar-se o depósito de sua prestação" (fl. 2.293). Sustenta contrariedade aos artigos $\underline{1.009}$ e $\underline{1.010}$ do Código Civil de 1916 na medida em que o Tribunal de origem considerou "possível a compensação da correção monetária que seria incidente nos pagamentos feitos antecipadamente, com a correção monetária contratualmente ajustada para os pagamentos efetuados em atraso" (fl. 2.305) e que, "não havendo credor e devedor por débitos recíprocos, tampouco dívidas líquidas e vencidas, não se poderá admitir compensação" (fl. 2.306).

Aponta dissídio jurisprudencial, colacionando julgados, também, desta Corte.

Sem contra-razões (fl. 2.354), o recurso especial (fls. 2.258 a 2.309) foi admitido (fls. 2.357 a 2.359$)$.

Houve recurso extraordinário (fls. 2.338 a 2.352), não admitido (fls. 2.357 a 2.359), tendo sido interposto agravo de instrumento contra essa decisão (fl. 2.365).

É o relatório.

RECURSO ESPECIAL No 712.173 - RS (2004/0179902-0)

EMENTA

Quitação. Embargos de declaração: julgamento em mesa, ausência de pressupostos e afastamento da multa. Impropriedade dos dispositivos apontados diante da situação de fato. Atualização monetária. Dissídio.

1. Diante dos fatos indicados pelo acórdão, não descartados pela parte, não se pode dizer que os embargos tenham sido julgados em sessão diversa daquela prevista no Código de Processo Civil, sendo postos em mesa na sessão seguinte à distribuição ao Relator. 
2. Afasta-se a existência da omissão quando a leitura dos acórdãos da apelação e dos declaratórios não deixa margem a nenhuma dúvida de que foram examinados todos os pontos de interesse para a causa e relevantes para o julgamento do Tribunal local.

3. Incabível é a multa do art. $\underline{538}$, parágrafo único, do Código de Processo Civil quando os embargos estão nos limites da Súmula $n^{\circ} 98$ da Corte.

4. Não há falar em violação dos dispositivos sobre a quitação, no cenário dos autos, examinada a prova pericial e documental que mostrou efetuados os pagamentos e justa a recusa quanto à última prestação, assentando o acórdão, ainda, a prevalência do adimplemento substancial e da recusa da parte recorrente no cumprimento de sua obrigação de outorga da escritura, fundamentos que passaram ao largo do especial.

5. A prova dos autos deitou por terra, como posto no acórdão, a alegada manobra dolosa do réu para iludir funcionário da autora quanto à quitação.

6. O dissídio não procede porquanto não guardam os paradigmas as mesmas bases fáticas dos autos.

7. Recurso especial conhecido e provido, em parte.

\section{VOTO}

\section{O EXMO. SR. MINISTRO CARLOS ALBERTO MENEZES DIREITO:}

A empresa recorrente ajuizou ação ordinária para requerer " $a$ declaração da inexistência do ato de quitação do contrato de compra e venda por dois fatos: um por erro espontâneo e outro por erro provocado por maquinação dolosa da parte adversa" (fl. 5). Afirma a inicial que, em "setembro de 1994, a Autora prometeu vender uma área de terras hipotecada por $R \$ 1,6$ milhão, Fazenda Luzia, e outra área, meses depois, em fevereiro de 1995, por $R \$$ 237.000,00, Fazenda Dona Luzia e Fazenda Batista” (fls. 5/6), ambos os contratos com pagamento parcelado. O réu, porém, prossegue a inicial, não conseguiu cumprir com suas obrigações, fazendo a autora novo parcelamento, ou seja, “ o réu ia pagando por conta, como podia, até completar o saldo" (fl. 6). Ainda, segundo a inicial, um funcionário da autora, Sr. Vicente, era o encarregado de controlar os pagamentos do $1^{\circ}$ contrato, ignorando, entretanto, a existência do $2^{\circ}$ contrato. $\mathrm{O}$ réu, diante da ignorância do funcionário, aproveitou-se disso e o induziu ao erro ao requerer a nota promissória a que não tinha direito (fl. 7). Assim, a maquinação dolosa consiste em que "o réu foi até o Sr. Vicente, reuniu-se com 
ele, e mostrou-lhe pagamentos parciais. Mas esses pagamentos parciais eram referentes ao $2^{o}$ contrato, dos quais já havia recebido o título diretamente do Banco. $O$ réu agiu iludindo o Sr. Vicente pelo conhecimento inexato de uma coisa, por saber ser incompleto, mostrando-lhe pagamentos feitos a um $2^{o}$ contrato, como se fosse do $1^{o}$. Aproveitou-se do defeito de conhecimento do verdadeiro estado das coisas e por isso obteve do Sr. Vicente uma concordância equivocada. De posse de tal fato o Sr. Vicente pegou o título e dirigiu-se à direção da empresa, onde pediu quitação do título. O título foi quitado com outras centenas de papéis, os quais diretores de empresa de grande porte como é o caso da autora, restringem-se assinar o que os responsáveis pelos setores lhes apontem (fl. 7). Para a empresa autora, o dolo e a má-fé do Sr. Vidaletti se evidenciam e se destacam quando apresenta a quitação de ambos os títulos dos dois contratos, tendo pago apenas uma vez. Não agiu com correção o Sr. Vidaletti que poderia no máximo entender como quitado um ou outro, mas nunca pretender alcançar duas quitações com apenas um pagamento (fl. 9). Entende também a inicial que há responsabilidade civil, sendo ilícita a atitude do réu, presente o dano contratual, representado significativamente pela ação de execução ajuizada com o intuito de obter escritura que não tem direito. A autora teve assim todos os seus bens indisponíveis, mais de $R \$ 40.000 .000,00$ de seu patrimônio paralisado para garantir uma ação de $R \$$ 1,2 milhão inclusive bens de terceiros ficaram indisponíveis. Mais de 200 funcionários estão parados por falta de atividades, correndo o risco de serem dispensados, pois não podem tocar na matéria-prima da empresa que são as árvores de eucalipto e de acácia negra que estão prontas para o corte e extração da casca. O prejuízo da empresa é de grande monta, pois tem de suportar os encargos salariais de seus funcionários sem produzir nada (fl. 14).

A sentença julgou improcedente o pedido. O Juiz, apoiado nas provas pericial e documental, entendeu desamparado de fundamento o pedido de resolução contratual, não vislumbrando o ventilado inadimplemento imputado à contraparte, nem sequer o direito aos acessórios (juros e correção monetária de parcelas quitadas), cumprindo ressaltar que filio-me a corrente que entende juridicamente possível o aforamento da ação de cumprimento (execução específica da obrigação de fazer), na hipótese de inadimplemento antecipado (fl. 2.059). Ademais, considerou que, na execução, uma vez malograda a prestação principal impossibilidade absoluta de prestar poderá, a requerimento do credor, ocorrer a conversão para a liquidação das perdas e danos, 
seja na forma de arbitramento ou por artigos, consoante a lição de JOSÉ FREDERICO MARQUES, em seu "Manual do Processo Civil", p. 196. Inteligência do disposto no artigo 633, segunda parte e parágrafo único, do Código de Processo Civil (fl. 2.059). Quanto ao afastamento das perdas e danos, afirmou a sentença que inocorreu ilícito contratual imputável ao requerido, de modo que, em não havendo a violação contratual, não há falar-se em pretensão indenizatória (fl. 2.060). Asseverou o Juiz que não vê como reconhecer o direito à indenização a quem recebeu da contraparte, ex vi de obrigação contratual, nos idos de 1994/1995, vultosa importância, da ordem de quase DOIS MILHÕES DE REAIS, não computada a correção monetária, o que seguramente suplantaria esta cifra (ou seja, a quase totalidade do preço ajustado para a aquisição das duas fazendas), e até hoje não envidou o mínimo esforço para o adimplemento de seus deveres contratuais (fls. 2.060/2.061). Os embargos de declaração foram rejeitados.

O Tribunal de Justiça do Rio Grande do Sul não conheceu do agravo retido e do recurso adesivo e desproveu a apelação. $\mathrm{O}$ acórdão descartou o agravo retido nos termos do art. $\underline{523}, \underline{4^{\circ}}$, do Código de Processo Civil. Quanto ao recurso adesivo, o acórdão afirma que o recorrente foi vitorioso, em termos práticos, em toda extensão possível (fl. 2.188). Finalmente, no tocante à apelação, o Tribunal local primeiro considerou que no caso dos autos, a ação autônoma apresenta causa de pedir e pedido distintos daqueles constantes nos embargos à execução (fl. 2.189), reforçando com a assertiva que se cuida de causas de pedir e pedido inteiramente refratários ao âmbito dos embargos de devedor, podendo-se ver conexão quanto a estes. Jamais litispendência. E nem se pode questionar a viabilidade de ação autônoma a atacar a dívida objeto de execução. A ela apenas se nega o efeito suspensivo, quanto à execução (fl. 2.189). Passando ao mérito, afirma o julgado que sobre questão envolvendo o fato de ter sido o empregado da empresa ludibriado, prova alguma existe nos autos a este respeito (fl. 2.193), a começar pelo fato de ser estranho que empregado qualificado como Doutel fosse ignorar a existência do outro contrato e os respectivos ingressos na contabilidade da empresa, assim como seus diretores não se dessem conta do ingresso a menor de valores respeitáveis” (fl. 2.193), afastando, portanto, à míngua de qualquer prova, a dita conduta dolosa do réu. Quanto à quitação, afirmou o Tribunal local que "os autos mostram que (1) houve a devolução dos títulos; (2) nenhuma ressalva há nas quitações neles lançadas que pudesse traduzir pagamento parcial; (3) decorrido tempo mais que 
suficiente para a constatação de algum erro ou pagamento a menor, nenhuma manifestação da credora houve, tendo esta apenas a 29 de janeiro de 1996 procedido à notificação pretendendo diferenças quanto às prestações vencidas em 27.06.95, 27.07.95 e 27.08.95 (as datas, precisas, encontram-se no laudo pericial, fl. 1.408), que somente podem ser as prestações de $n^{o}$ s 10 a 12 do primeiro contrato (fl. 17, autos dos embargos à execução conexos; as datas do segundo contrato, inteiramente distintas, estão no laudo a fl. 1.409), o que, aliás, corresponde ao que constava na própria contabilidade da autora (laudo pericial, fl. 1.412); (4) esta dispensou,expressamente, ao menos quanto a três promissórias e duas prestações (as prestações $7^{a}$ e $8^{a}$ ), a incidência de correção monetária, em comunicação dirigida ao banco, a 17.03.95 (fl. 499)” (fl. 2.196). Depois de analisar a prova dos autos, afirma que "na própria notificação procedida pela autora nada consta quanto à $9^{a}$ parcela, a evidenciar que agora tenta esta ressuscitar créditos mais que sepultados” (fl. 2.198). Relativamente ao segundo contrato, assevera o acórdão que o "banco recebeu as duplicatas, cobrou-as, entregou-as ao réu, e, depois, vem-se pretender a correção monetária, quando aquele agia como nítido mandatário da autora, e nada mais estranho que tivesse dispensado a correção monetária” (fl. 2.198). Por outro lado, com base no laudo pericial, o Tribunal local afirmou que "não se pode atribuir valor probante absoluto aos lançamentos constantes da contabilidade da autora e aos seus documentos” (fl. 2.200). Em seguida, o acórdão passa a examinar as parcelas que não teriam sido pagas por inteiro. Começa por dizer que a contabilidade da autora "não apresenta saldo devedor em relação à $9^{a}$ prestação, assim como a própria notificação feita pela autora, como já visto acima, embora pretenda esta diferença, a seu favor, decorrente de atraso no pagamento” (fls. 2.200/2.201). E, com base no laudo pericial, assevera que “(a) até a $6^{a}$ prestação, não incidia correção monetária, já se tendo examinado acima, quanto a esta última parcela, o nenhum atraso, inexistindo dúvidas a respeito de seu integral pagamento (laudo, fl. 1.428); (b) a partir da $7^{a}$ parcela, passou a incidir a atualização monetária, mas há o documento de fl. 499, dispensando incidência de correção monetária quanto a ela e à $8^{a}$ parcela (observo que não foi localizada a promissória correspondente à $8^{a}$ parcela); (c) no que diz com a $9^{a}$ parcela (cuja promissória está desaparecida), viu-se que nem a contabilidade da autora, nem a notificação por ela procedida, apontam resíduo; $e$ atinente à $10^{a}$ prestação, acima se viu a questão correspondente ao recibo de fl. 488 e demais dados a indicar o seu integral pagamento; (d) resta a $11^{a}$ prestação, das que 
foram pagas, a cujo respeito afastou-se, supra, a tese do dolo quanto à quitação nela lançada. A ausência de registro contábil de parte da autora, ante o que se viu relativamente à confiabilidade da mesma, não arreda a presunção de pagamento” (fls. 2.202/2.203). Segundo o acórdão, o comportamento da autora ofende a boa-fé objetiva, quando "resolveu, contra todo o seu comportamento anterior, contra tudo aquilo que se fora forjando no seu relacionamento com a contraparte, beneficiando-se ela aqui e ali, cedendo, em contrapartida, direitos seus, para, chegado o momento de adimplir, na impossibilidade decorrente da sua penúria financeira, vir tentar resgatar o que sabia melhor do que ninguém já estava consumido de muito" (fl. 2.204). Finalmente, o acórdão examina os pedidos e dá as respostas respectivas nos termos que se seguem:

"Quanto ao segundo contrato, não há pedido de resolução. Postulou-se, apenas, seja declarado não haver quitação: pedido, itens 2.1, 3 e 4. A "declaração constitutiva" (sic) de que o réu seria inadimplente em ambos os contratos, na realidade, quanto ao primeiro contrato, em que pedida resolução ("rescisão") corresponde a mera causa de pedir e, pois, motivação decisória do verdadeiro pedido (o de resolução, item 4.2). Quanto ao segundo contrato, abrange-se ela com a declaração de persistência da relação jurídica e conseqüente débito do réu.

Ora, no que se refere a este último contrato, afastou-se acima, por inteiro, qualquer débito do réu, e os pedidos (na verdade pedido declaratório único) a ele relacionados apresentam-se inteiramente improcedentes. Ainda que se queira extrair da alusão à "declaração constitutiva" pretensão à resolução de tal contrato, a mesmíssima razão leva a que também aqui haveria rematada improcedência.

Como corolário, a indenização pretendida com base no inadimplemento de tal contrato (item 8.2, embora a redação no singular e a norma do art. 293, CPC, e item 8.3) afigura-se de todo descabida.

Resta o primeiro contrato e sua resolução, ante inadimplemento que, a estas alturas, resumir-se-ia à $12^{a}$ parcela.

Não há dúvidas de que mais de oito anos após a data em que a autora deveria ter condições de outorgar a escritura definitiva quanto aos imóveis negociados, não o fez, senão quanto a dois, e nem poderia fazê-lo em relação aos demais, por estarem eles afetados por hipotecas em favor do Banco do Brasil S/A. Não consta dos autos decisão favorável à autora que tenha liberado os imóveis das hipotecas, o que leva à 
constatação de que não se está diante de simples dificuldade ou mera impossibilidade temporária.

E, conquanto a autora tenha sobrevivido até o presente momento, a sua situação financeira apresenta-se periclitante, o que se traduz nos documentos das fls. 412 a 439, não demonstrando ela ter reduzido, ao menos, o número de demandas contra si.

A sentença, no passo, raciocinou em termos de recusa antecipada do devedor em cumprir a prestação.

Na jurisprudência, tem-se admitido a recusa à prestação em face do inadimplemento antecipado. Anota-se julgado do Tribunal de Justiça em que se definiu a sustação do pagamento das cotas mensais relativas a serviços hospitalares, quando constatado que nem se iniciara a construção do hospital (RJTJRGS 97/397, rel. ATHOS GUSMAO CARNEIRO).

O que não deixaria de ser, em substância, manejo da exceção do art. 1.092, CC/1916. Na mesma linha, observa RUY ROSADO DE AGUIAR JUNIOR a plena possibilidade de se reter a prestação, no aguardo da iniciativa da contraparte em atender tais deveres (Ob. cit., p. 192).

Tenho que é o que ocorre no caso dos autos, quando o réu pagou onze de doze prestações, praticamente adimplindo o primeiro contrato, é dizer, houve o adimplemento substancial.

No caso, embora 12 parcelas, desdobraram-se elas em vários pagamentos parciais, o que mostra a reiterada adimplência do réu até chegar à última parcela. Que não pagou por motivos justificáveis, como se está a ver e se continuará a tratar.

Enquanto isso, a autora se afigura nitidamente inadimplente quanto a dever acessório básico, qual seja, o de providenciar na liberação dos imóveis, o que não fez e não dá qualquer sinal de que irá fazê-lo por si. Mais, à medida que exige do réu valores de todo indevidos, resguardando-se a atender suas obrigações no aguardo de que haja dita satisfação, está aí conduta incompatível com o adimplemento.

Justifica-se, assim, a retenção da derradeira prestação pelo réu, que não pode ser considerado inadimplente. 
Com o que vai repelido o pedido de resolução quanto ao primeiro contrato, destacando que os demais pleitos de natureza declaratória já se encontram repelidos em relação a ela, afastada a idéia de algum inadimplemento de parte do réu. Observo, a evitar dúvidas, que não se questiona o não-pagamento da $12^{a}$ parcela do referido contrato (aliás, como se viu, o réu ofertou o depósito desta na ação de execução), desnecessária toda e qualquer declaração a respeito. Agora, o que não se pode afirmar é de que tal ausência de pagamento advenha inadimplemento, coisa que, penso, restou acima devidamente esclarecida e julgada.

Por conseqüência, restam também improcedentes os pedidos indenizatórios formulados quanto a ele, incluindo-se aqui aquele atinente à manobra dolosa, já antes repelida" (fls. 2.204 a 2.210).

Os embargos de declaração foram rejeitados. Novos embargos foram interpostos e também rejeitados com imposição de multa.

O longo recurso especial com 52 laudas começa com preliminar de quebra do princípio do devido processo legal e da publicidade, apontando violação dos artigos $\underline{537}$ e $\underline{552}$ do Código de Processo Civil. Afirma que há prequestionamento dos dispositivos diante da interposição dos embargos de declaração, para, em seguida, dizer que existe violação do art. $\underline{535}$ do Código de Processo Civil, porque o Tribunal local não enfrentou o ponto. Vejamos.

Nos segundos embargos declaratórios é que surge o tema ao argumento de que o recurso deveria ter sido julgado na sessão subseqüente, o que não ocorreu embora estivessem os embargantes presentes, sendo julgado na semana seguinte. Mas o Tribunal local rechaçou expressamente essa argüição afirmando, também, que "a embargante abusa da própria má litigância” (fl. 2.249). Segundo o acórdão os embargos declaratórios, foram protocolados "quase ao final do expediente da segunda-feira, foram distribuídos no dia seguinte (fl. 2.217v). Remetidos à Secretaria da Câmara, foram juntados no dia 20 de novembro (fl. 2.213v). Recebidos no gabinete no dia 21 (fl. 2.221). A primeira sessão subseqüente à recepção se deu no dia 26 de novembro, quando então foram efetivamente julgados" (fl. 2.250). Verifica-se com muita claridade que, de fato, a impugnação carece de qualquer substância, valendo anotar que sequer no especial a parte recorrente contrasta a situação de fato apresentada no julgado. Ficam, portanto, afastadas as alegadas violações dos artigos 535, $\underline{537}$ e $\underline{552}$ do Código de Processo Civil. 
A segunda violação trazida é do artigo $\underline{538}, \underline{1^{\circ}}$, do Código de Processo Civil ao fundamento de que não são embargos protelatórios os que a recorrente interpôs, "visto que o recurso possui a finalidade única de prequestionar artigos violados quando do julgamento do primeiro recurso aclaratório" (fl. 2.275). Nas circunstâncias existentes nos autos, ainda mais quando se trata de advogados com experiência forense, como me parece o caso, não há nenhum fundamento na impugnação considerando que não se pode exigir o julgamento dos embargos na sessão seguinte à data em que protocolados, mas, sim, da data em que chegou ao Relator, o que foi feito nestes autos, segundo revela o acórdão e não contestado pela parte recorrente. No entanto, creio que merece relevada a multa. É que o tema foi trazido para exame do Tribunal local no exercício do direito da parte, sendo que os segundos embargos de declaração apresentaram matéria nova ocorrente quando do julgamento dos primeiros embargos.

Em seguida, o especial traz nova argüição de que violado o art. $\underline{535}$ do Código de Processo Civil ao argumento de que não teria sido considerado o fato de que a $12^{\mathrm{a}}$ parcela não foi paga. Para a recorrente, "a própria adoção da tese do adimplemento substancial, a afastar a inadimplência do recorrido, bem demonstra que não houve pagamento integral das parcelas contratadas” (fl. 2.283). Assim, a afirmação de que não houve pagamento da última parcela "é absolutamente incompatível com o desacolhimento do primeiro pedido formulado na presente ação, acima transcrito, qual seja," a declaração da inexistência de QUITAÇAO do primeiro contrato "” (fls. 2.283/2.284). Mas é baldio o argumento para indicar a violação do dispositivo. Não existe contradição alguma, estando bem claro no aresto que o acórdão considerou o tema e, ainda, entendeu que esse fato estava enquadrado no chamado adimplemento substancial, retirando força para a pretendida declaração de inexistência de quitação. Não ajuda à recorrente o raciocínio desenvolvido sobre a diferença entre inadimplemento e ausência de quitação, diante da circunstância de que se está examinado aqui se houve violação do art. $\underline{535}$ do Código de Processo Civil. E não houve porque o fato essencial, isto é, a falta de pagamento da última prestação e sua consequiência sobre o pedido, foi efetivamente desafiado pelo acórdão, não se podendo enxergar contradição.

Prossegue o longo especial trazendo novamente o art. $\underline{535}$ do Código de Processo Civil, desta feita para afirmar o "silêncio do c. órgão colegiado a respeito de diversas questões suscitadas nos embargos" (fl. 2.286), sendo esta a finalidade primeira do 
especial. Em que consiste a alegação? No-lo diz o especial ao afirmar que os "recorrentes opuseram embargos de declaração para fins das súmulas 282 e 356 do STF e 211 do STJ, prequestionando, entre outros temas, a negativa de vigência à Lei da Correção Monetária, afronta ao princípio do pacta sunt servanda, enriquecimento sem causa, ofensa aos artigos $\underline{940}$ e 943 do Código Civil/1916, princípios da autonomia, abstração e independência dos títulos de crédito, negativa de vigência aos artigos 959 ,

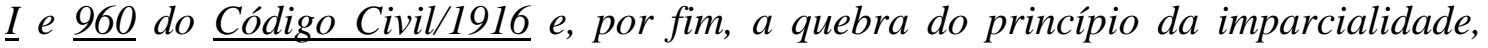
mormente a afronta aos artigos 125, 128, 459 e 460 do CPC” (fl. 2.286). A pretensão, como se vê, é para que o Tribunal local se pronuncie sobre cada um dos dispositivos mencionados. Vejamos o que disse o acórdão dos declaratórios.

Primeiro, afirmou o acórdão que o pedido de declaração da inexistência de quitação foi expressamente tratado; segundo, que nunca houve negativa de que a parcela deixou de ser paga; terceiro, que "o não-pagamento não leva, por si, à situação de inadimplemento, que supõe, lógico, a exigibilidade, o que não ocorria quanto a tal parcela, tema fundamentadamente apreciado no julgado” (fls. 2.226/2.227); quarto, não há nem contradição nem definição teratológica "em remanescer uma das parcelas do débito e não se configurar quadro de inadimplemento quanto a ela" (fl. 2.227); quinto, ademais, “diante das multas impostas à ora embargante, e por força da compensação que eventualmente possa ser invocada pela outra parte, bem se poderia questionar se efetivamente persiste o débito relativo à $12^{a}$ parcela. Matéria, de qualquer sorte, estranha ao presente feito" (fl. 2.227); sexto, que na "segunda ordem de defeitos, anoto que a embargante, prefiro pensar que não intencionalmente, troca o dispositivo legal considerado como um dos componentes da quitação relativa às parcelas de 1 a 11, qual seja, o art. 945, com outro dispositivo, é dizer, o art. 943, ambos do CC/1916” (fl. 2.227), revelando bem “a fragilidade da sustentação” (fl. 2.227); sétimo, "tenta-se reavivar o exame dos fatos e a avaliação da prova, quanto (1) ao pagamento e (2) à quitação, pretensão imprópria para embargos declaratórios” (fl. 2.227); oitavo, o acórdão observou que "no julgado embargado examinou-se, com minúcia, a inocorrência de mora do réu quanto à derradeira parcela, tendo sido feita ampla análise da prova documental, pericial e oral, não se podendo aceitar nova análise destas, sob pena de se configurar a aclaratória em segunda apelação” (fl. 2.228); nono, no que se refere com a "terceira linha de argumentos" (fl. 2.228), disse o acórdão que a "quebra positiva do contrato encontra-se posta na defesa do réu, 
inobstante ausente melhor referência doutrinária ou jurisprudencial a seu respeito. Mas, está dita e descrita, com todas as letras, a inviabilização do adimplemento com a realização dos negócios definitivos" (fl. 2.228), sendo que a sentença "considerou o inadimplemento antecipado, sem que a apelação fizesse única crítica a ela e lhe atribuísse infração ao princípio da demanda ou quebra da imparcialidade” (fl. 2.228); décimo, para o acórdão, a quebra positiva do contrato não foi o único argumento utilizado, mas, também, o adimplemento substancial.

Sem a menor sombra de dúvida, não é possível identificar qualquer violação do art. $\underline{535}$ do Código de Processo Civil. O Tribunal local foi minucioso tanto no acórdão da apelação como no dos declaratórios, rebatendo a argumentação apresentada pela parte e fundamentando com perfeita adequação o julgado.

Na parte de mérito, o especial começa por apontar violação do art. $\underline{940}$ do Código Civil de 1916. O princípio que está por traz da alegação é o de que se existe quitação, esta ocorre apenas no tocante às parcelas recebidas, e não ao contrato, para evitar o enriquecimento sem causa. A pretensão, portanto, é que o acórdão teria considerado quitados valores não previstos na quitação, invocando precedente da Corte. Mas não creio que exista violação. Primeiro, anoto que a alegação está feita de modo genérico, deixando a recorrente de pormenorizar em que consistiria esta situação no caso dos autos. No entanto, deixando isso de lado, a leitura do acórdão mostra que o exame da prova dos autos, incluída a pericial, conduziu o Tribunal local a outra conclusão. Vale lembrar que toda a argüição trazida na inicial diz com a má-fé do réu que teria conduzido funcionário da empresa a confundir os dois contratos e seus respectivos pagamentos. O acórdão, contudo, examinou detalhadamente os pagamentos efetuados, a contar da indicação da autora de que o réu teria começado a atrasar desde a $6^{\mathrm{a}}$ prestação do primeiro contrato, faltando parte da $9^{\mathrm{a}}$ parcela e da $10^{\mathrm{a}}$ parcela, levando em conta juros e correção monetária, o mesmo ocorrendo com a $11^{\mathrm{a}}$ prestação, exigível desde 24/7/95, em que teria havido a manobra dolosa, "valendo-se de pagamentos parciais referentes ao segundo contrato, obtendo a quitação da nota promissória representativa de $R \$ 200.000,00 ”$ (fl. 2.190). O acórdão logo descartou a alegação de manobra dolosa relativamente ao pagamento da $11^{\mathrm{a}}$ parcela, à míngua de provas, passando, então, a examinar "o que foi pago e se houve dispensa de correção monetária e juros de mora contratados" (fl. 2.195). O acórdão apoiou-se no laudo pericial e, depois de entender 
que a quitação no direito brasileiro é encarada de modo restrito, funcionando de acordo com a verdadeira liberação conferida pelo credor, deduziu as razões que se seguem:

“Ora, os autos mostram que (1) houve a devolução dos títulos; (2) nenhuma ressalva há nas quitações neles lançadas que pudesse traduzir pagamento parcial; (3) decorrido tempo mais que suficiente para a constatação de algum erro ou pagamento a menor, nenhuma manifestação da credora houve, tendo esta apenas a 29 de janeiro de 1996 procedido à notificação pretendendo diferenças quanto às prestações vencidas em 27.06.95, 27.07.95 e 27.08.95 (as datas, precisas, encontram-se no laudo pericial, fl. 1.408), que somente podem ser as prestações de $n^{o}$ s 10 a 12 do primeiro contrato (fl. 17, autos dos embargos à execução conexos; as datas do segundo contrato, inteiramente distintas, estão no laudo a fl. 1.409), o que, aliás, corresponde ao que constava na própria contabilidade da autora (laudo pericial, fl. 1.412); (4) esta dispensou, expressamente, ao menos quanto a três promissórias e duas prestações (as prestações $7^{a}$ e $\left.8^{a}\right)$, a incidência de correção monetária, em comunicação dirigida ao banco, a 17.03.95 (fl. 499)" (fl. 2.196).

Com isso, não tem qualquer cobertura a impugnação em torno do art. $\underline{940}$ do Código Civil de 1916, ainda mais porque o acórdão considerou que o comportamento das partes levou ao entendimento de que não haveria, quanto a outras parcelas, a exigência de atualização monetária, sem falar na antecipação de alguns pagamentos efetuados pelo réu, como está no laudo pericial. Tais adiantamentos, como bem posicionou o Tribunal local, foram feitos "para atender a necessidades financeiras da autora, que eram de molde tal a, entre outras coisas, levar esta a criar duplicatas sem qualquer negócio subjacente, consoante ver-se-á. Daí a contrapartida” (fl. 2.197). Também assinalou o Tribunal de origem não ser usual "que o credor não proceda a qualquer ressalva $e$, mais, vá, numa reserva mental, guardando para o final a suposta diferença relativa à atualização monetária e juros" (fl. 2.198), além do que bem demonstrou a perícia que o banco "recebeu as duplicatas, cobrou-as, entregou-as ao réu, e, depois, vem-se pretender a correção monetária, quando aquele agia como nítido mandatário da autora, e nada mais estranho que tivesse dispensado a correção monetária” (fl. 2.198), isso já no que concerne ao segundo contrato. Como se vê, não tem espaço para expandir-se a alegação de que violado o art. $\underline{940}$ do Código Civil anterior.

A próxima alegação trazida no especial é quanto aos artigos $\underline{959}, \underline{\mathrm{I}}, \underline{960}, \underline{973}, \underline{\mathrm{V}}$, e $\underline{974}$ do Código Civil revogado. Aqui está o ponto nuclear da impugnação, isto é, se houve o 
reconhecimento de que estava o réu inadimplente no pagamento da última parcela não seria crível julgar-se improcedente o pedido de resolução contratual pela mora do devedor, notando-se que foi o devedor constituído em mora. O argumento tem força, contudo passa ao largo da fundamentação do acórdão que está laçado ao princípio de que houve adimplemento substancial e de que o não-pagamento foi justificado diante do descumprimento da autora na outorga da escritura considerando o gravame existente em benefício de instituição financeira. Os dispositivos, portanto, não têm o condão de desarmar o fundamento do julgado. O art. 959, I, cuida da purga da mora; o art. 960 trata do inadimplemento da obrigação no seu termo capaz de constituir de pleno direito o devedor em mora; o art. 973 trata da consignação; finalmente, o art. 974 estabelece os requisitos para que a consignação tenha força de pagamento. Ora, o que o Tribunal local considerou foi que havia justificativa para o não-pagamento da última parcela e que houve o adimplemento substancial, ambos os fundamentos fora do âmbito dos dispositivos apontados.

Vamos agora para a parte final do recurso que traz os paradigmas da Corte.

O primeiro paradigma é da Quarta Turma, cuidando do pagamento efetuado sem o cômputo da correção monetária e sem que tivesse sido feita nenhuma referência a que o credor tenha a ela renunciado, não excluindo, assim, a quitação dada à faculdade de se pleitear a correção monetária, sobretudo quando há previsão contratual. Aqui, tenho que o precedente não serve. Não serve porque o Tribunal local, neste caso, expressamente examinou a questão do pagamento da correção monetária concluindo, como já vimos antes, que os recibos foram dados sem ressalva, que teria havido pagamento antecipado, que os títulos foram devolvidos, que houve cobrança bancária com entrega das duplicatas ao réu, que não houve notificação do réu quanto ao segundo contrato, que o laudo pericial afirmou que considerados os valores nominais, ou seja, sem correção monetária, os pagamentos foram feitos nas datas previstas, sendo que as duplicatas foram descontadas e o banco cobrou juros quando do atraso, que, pelo menos quanto a três promissórias e duas das prestações, a autora expressamente dispensou a incidência de correção monetária em comunicação dirigida ao banco e, finalmente, a natureza da argüição principal, isto é, de que a quitação teria sido dada com erro, havendo vício de consentimento, e, ainda, fez o exame da contabilidade da empresa. Esses aspectos, na minha compreensão, afastam a identidade fática necessária para que o precedente ampare a pretensão. 
O segundo paradigma diz que havendo quitação sem ressalva presume-se o pagamento apenas quanto ao principal, podendo tal presunção ser afastada mediante prova em contrário. Ademais, o paradigma assinala que existem inúmeros precedentes que admitem a cobrança da correção monetária, ainda que sem ressalva a quitação. Ora, no caso, o tema da correção monetária foi esmiuçado pelo acórdão considerando a prova dos autos de que teria havido dispensa por parte da credora, e outras circunstâncias de fato que indicou e que antes resumi. Veja-se, ainda, que o pedido, neste caso, diz com a rescisão do primeiro contrato diante da inadimplência gerada pela falta de quitação, que, como já vimos, decorreu de erro do funcionário da própria autora, e de manobra dolosa do réu, o que foi afastado pelo acórdão por falta de provas. Não se trata, portanto, de cobrança de saldo residual e de correção monetária em contrato administrativo. Não existe, portanto, ainda neste segundo paradigma embasamento para que seja reconhecida a divergência.

Os precedentes tratam da possibilidade da ação de cobrança da diferença de correção monetária, o que não se nega neste julgado. Aqui, o que se enfrenta é se a realidade dos autos autoriza a pretensão da declaração de ausência de quitação das prestações seja por manobra dolosa do réu, que teria iludido funcionário da autora, seja pela razão de não ter sido paga parcela relativa à correção monetária. E em ambos os casos, as instâncias ordinárias entenderam que a realidade da prova afastava as alegações, no primeiro argumento repelindo a existência de manobra dolosa; no segundo, considerando que houve dispensa da correção monetária.

Ultrapassada a questão da divergência, o especial volta para a letra a do dispositivo constitucional trazendo alegação de que violados os artigos $\underline{1.009}$ e $\underline{1.010}$ do Código Civil. Mas, aqui, não há o que examinar. O acórdão passou ao largo do tema, fazendo menção às multas sofridas pela autora como mera referência, obter dictum, sem repercussão no julgado. Ademais, a questão dos pagamentos adiantados também foi utilizada de passagem como possível de ser apenas argumento no afastamento da correção monetária contratualmente ajustada. Por fim, destaco que nem nos primeiros nem nos segundos embargos de declaração os dispositivos foram mencionados.

Com as razões acima deduzidas, conheço do especial, em parte, e, nessa parte, dou-lhe provimento para afastar a multa imposta no acórdão dos segundos embargos de declaração. 


\section{CERTIDÃO DE JULGAMENTO}

\section{TERCEIRA TURMA}

Número Registro 2004/0179902-0

REsp 712173/RS

Número Origem: 1020001241370007283435

PAUTA: 17/10/2006

JULGADO: 17/10/2006

Relator

Exmo. Sr. Ministro CARLOS ALBERTO MENEZES DIREITO

Presidente da Sessão

Exmo. Sr. Ministro CASTRO FILHO

Subprocurador-Geral da República

Exmo. Sr. Dr. PEDRO HENRIQUE TÁVORA NIESS

Secretária

Bela. SOLANGE ROSA DOS SANTOS VELOSO

AUTUAÇÃo

RECORRENTE: AGROSETA S/A

ADVOGADOS: MÁRCIO LOUZADA CARPENA E OUTROS JAQUELINE FRANCESCHETTI E OUTRO

RECORRIDO: JAIR JOÃO VIDALETTI

ADVOGADO: $\quad$ RITA PERONDI E OUTRO

ASSUNTO: Civil - Contrato - Compra e Venda - Imóvel - Promessa

\section{SUSTENTAÇÃO ORAL}

Pelo recorrente, Dr. Valternei Melo de Souza.

\section{CERTIDÃO}

Certifico que a egrégia TERCEIRA TURMA, ao apreciar o processo em epígrafe na sessão realizada nesta data, proferiu a seguinte decisão: 
A Turma, por unanimidade, conheceu em parte do recurso especial e, nessa parte, deulhe provimento, nos termos do voto do Sr. Ministro Relator. Os Srs. Ministros Nancy Andrighi, Castro Filho, Humberto Gomes de Barros e Ari Pargendler votaram com o Sr. Ministro Relator.

Brasília, 17 de outubro de 2006

SOLANGE ROSA DOS SANTOS VELOSO

Secretária

Documento 655887 Inteiro Teor do Acórdão $\quad$ DJ. 12/03/2007 
RECURSO ESPECIAL No 1.215.289 - SP (2010/0177513-3)

RELATOR : MINISTRO SIDNEI BENETI RECORRENTE : HUGO ENEAS SALOMONE ADVOGADO : SABRINA BERARDOCCO CARBONE E OUTRO(S) RECORRIDO : ANITO GONÇALVES E OUTRO ADVOGADO : MARCIA APARECIDA DA SILVA ANNUNCIATO E OUTRO(S) EMENTA DIREITO CIVIL. CONTRATO DE VENDA E COMPRA DE IMÓVEL. OTN COMO INDEXADOR. AUSÊNCIA DE ESTIPULAÇÃO CONTRATUAL QUANTO AO NÚMERO DE PARCELAS A SEREM ADIMPLIDAS. CONTRATO DE ADESÃO. INTERPRETAÇÃO MAIS FAVORÁVEL AO ADERENTE. EXCEÇÃO DO CONTRATO NÃO CUMPRIDO. AFASTADA. INADIMPLEMENTO MÍNIMO VERIFICADO. ADJUDICAÇÃO COMPULSÓRIA CABÍVEL. APLICAÇÃO DA EQUIDADE COM VISTAS A CONSERVAÇÃO NEGOCIAL. APLICAÇÃO DA TEORIA DO ADIMPLEMENTO SUBSTANCIAL. DISSÍDIO NÃO DEMONSTRADO. 1.- Demanda entre promitente vendedor e promitente comprador que se comprometeu a pagar o valor do imóvel em parcelas indexadas pela já extinta OTN. Na ocasião, as partes acordaram que o adquirente arcaria com um valor equivalente a certo número de OTN's estabelecido no contrato. No entanto, no instrumento particular de compra e venda não restou definida o número de prestações a serem pagas. 2.- O Tribunal de origem sopesou o equilíbrio entre o direito do adquirente de ter o bem adjudicado, após pagamento de valor expressivo, e o direito do vendedor de cobrar eventuais resíduos. Nesse diapasão, não há que se falar em violação do dispositivo mencionado referente à equidade. O artigo 127 do Código de Processo Civil, apontado como violado, não constitui imperativo legal apto a desconstituir o fundamento declinado no acórdão recorrido no sentido de se admitir a ação do autor para garantir o domínio do imóvel próprio, reservando-se ao vendedor o direito de executar eventual saldo remanescente. 3.- Aparente a incompatibilidade entre dois institutos, a exceção do contrato não cumprido e o adimplemento substancial, pois na verdade, tais institutos coexistem perfeitamente podendo ser identificados e incidirem conjuntamente sem ofensa à segurança jurídica oriunda da autonomia privada. 4.- No adimplemento substancial tem-se a evolução gradativa da noção de tipo de dever contratual descumprido, para a verificação efetiva da gravidade do descumprimento, consideradas as conseqüências que, da violação do ajuste, decorre para a finalidade do 
contrato. Nessa linha de pensamento, devem-se observar dois critérios que embasam o acolhimento do adimplemento substancial: a seriedade das conseqüências que de fato resultaram do descumprimento, e a importância que as partes aparentaram dar à cláusula pretensamente infringida. 5.- Recurso Especial improvido.

\section{ACÓRDÃO}

Vistos, relatados e discutidos os autos em que são partes as acima indicadas, acordam os Ministros da Terceira Turma do Superior Tribunal de Justiça, por unanimidade, negar provimento ao recurso especial, nos termos do voto do Sr. Ministro Relator. Os Srs. Ministros Paulo de Tarso Sanseverino, Ricardo Villas Bôas Cueva e Nancy Andrighi votaram com o Sr. Ministro Relator. Brasília (DF), 05 de fevereiro de 2013 (Data do Julgamento) Ministro SIDNEI BENETI Relator

RECURSO ESPECIAL Nº 1.215.289 - SP (2010/0177513-3) RELATOR : MINISTRO SIDNEI BENETI RECORRENTE : HUGO ENEAS SALOMONE ADVOGADO : SABRINA BERARDOCCO CARBONE E OUTRO(S) RECORRIDO : ANITO GONÇALVES E OUTRO ADVOGADO : MARCIA APARECIDA DA SILVA ANNUNCIATO E OUTRO(S) RELATÓRIO O EXMO. SR. MINISTRO SIDNEI BENETI (Relator): 1.- HUGO ENEAS SALOMONE interpõe Recurso Especial fundamentado no artigo 105, inciso III, alíneas "a" e "c", da Constituição Federal contra Acórdão (e-STJ fl. 542) do Tribunal de Justiça do Estado de São Paulo que lhe foi desfavorável (RELATOR DES. ÊNIO SANTARELLI ZULIANI). 2.- No caso em apreço, os recorridos ajuizaram ação de adjudicação compulsória cumulada com declaratória de quitação de outorga de escritura e ainda, com restituição de valores pagos indevidamente em face do recorrente. Os autores adquirentes, ora recorridos litigantes celebraram compromisso de compra e venda com a ré, ora recorrente, de imóvel residencial situado no loteamento denominado Parque Savoy City, $38^{\circ}$, Subdistrito de Vila Matilde/SP, no ano de 1986. Os adquirentes, ora recorridos, comprometeram-se a pagar o valor do imóvel em parcelas corrigidas pela já extinta OTN. Assim, ficou contratualmente acertado entre as partes que os adquirentes pagariam a entrada no importe de 112 OTN's e, 1854 OTN's, em prestações consecutivas restantes. Desse modo, as partes acordaram que o adquirente arcaria com 
um valor equivalente a certo número de OTN's estabelecido no contrato. No instrumento particular não restou definido, em princípio, o número de prestações a serem pagas. Após os adquirentes, ora recorridos adimplirem 182 prestações, consideraram eles quitada a obrigação junto ao alienante. Tal fato foi rechaçado pelo Documento: 1207397 - Inteiro Teor do Acórdão - Site certificado - DJe: 21/02/2013 Página 3 de 4 Superior Tribunal de Justiça requerido, ora recorrente, que afirma existir saldo residual a ser pago pelos recorridos. A pretensão dos autores, ora recorridos, foi julgada improcedente na primeira Instância (e-STJ fl. 364/371). A sentença pautou-se, basicamente, pelo laudo do contador judicial, que evidenciou a existência de saldo devedor no montante de 1.091,43 OTN's a ser adimplido pelos recorridos. Assim, o juízo singular inadmitiu a adjudicação pleiteada pelos autores. Inconformados, os autores apelaram e obtiveram êxito por votação majoritária. O Acórdão da apelação foi assim ementado (e-STJ fl. 460/471): Adjudicação compulsória - Oportunidade de aplicar a teoria do adimplemento substancial - Compromisso de venda e compra de lotes comercializados com preço atrelado em OTNS e que, a exemplo de outros provenientes do mesmo loteamento, engrossa a polêmica jurisprudencial acerca da controvertida questão do pagamento do preço - Na dúvida de existência de saldo, cabe interpretação por equidade, para que o compromissário que quitou todas as cento e oitenta e duas prestações, construindo no terreno a sua casa, obtenha a tutela específica que consolide o domínio, reservando-se ao vendedor o direito de obter, em ação própria, sentença que possibilite a execução do saldo que afirma existir - Provimento para esse fim. Foram interpostos embargos de declaração, alegando omissão do Acórdão da apelação, sendo, à unanimidade, rejeitados (e-STJ fl. 510). 3.- O réu, ora recorrente, interpôs, então, Embargos Infringentes, sem sucesso. O Acórdão dos Embargos Infringentes foi assim ementado (e-STJ fls. 542/562): EMBARGOS INFRINGENTES - Adjudicação compulsória - Compromisso de compra e venda -Contrato de adesão contendo cláusulas contraditórias entre si - Interpretação mais favorável ao aderente, contra o estipulante que redigiu o contrato - Cobrança de resíduo decorrente da variação mensal de OTNs Longa inércia do promitente vendedor, durante quinze anos, que Documento: 1207397 Inteiro Teor do Acórdão - Site certificado - DJe: 21/02/2013 Página 4 de 4 Superior Tribunal de Justiça impossibilita a cobrança de eventual resíduo no momento da lavratura da escritura - Violação ao princípio da boa-fé objetiva e da confiança despertada no adquirente - Boa-fé objetiva, na função de controle (supressio) - Ação de 
adjudicação compulsória procedente - Embargos infringentes rejeitados. 4.- Por fim, o devedor recorrente interpõe Recurso Especial em que alega violação dos artigos 333, I e 127 do Código de Processo Civil; 476, 884, 885 do Código Civil e art. 15 do Dec. Lei 58/37. Assevera em suas razões: a) Impossibilidade da aplicação da equidade; b) Incidência da exceção do contrato não cumprido; c) Ocorrência de locupletamento ilícito; d) Impossibilidade de adjudicação compulsória e ausência de provas constitutivas do direito do autor. Suscita, ainda, dissídio jurisprudencial. É o breve relatório. Documento: 1207397 - Inteiro Teor do Acórdão - Site certificado - DJe: 21/02/2013 Página 5 de 4 Superior Tribunal de Justiça RECURSO ESPECIAL No 1.215.289 - SP (2010/0177513-3) VOTO O EXMO. SR. MINISTRO SIDNEI BENETI (Relator): 5.- Consigna-se, inicialmente, que, no caso em exame, discute-se a incidência da teoria do "adimplemento substancial" também denominada de "inadimplemento mínimo", que visa a impedir o uso desequilibrado do direito de resolução do contrato por parte do credor, em prol da preservação da avença, com vistas à realização dos princípios da boa-fé e da função social do contrato conforme disposto no enunciado 361 do Conselho de Justiça Federal. 6.- O recorrente insurge-se contra a aplicação do princípio da equidade utilizado pelo Acórdão combatido, o qual enfatizou que: "Cabe aqui, um julgamento de equidade. A jurisprudência do Tribunal não se pacifica, pois enquanto julgados dão razão aos compradores, outros recusam a adjudicação compulsória. Caberia, um meio termo plenamente satisfatório, qual seja, admitir a ação do autor para garantir o domínio do imóvel próprio, reservando-se ao vendedor o direito de executar eventual saldo, em provando sua existência em ação apropriada para esse fim. Anoto que essa resolução cumpre ao sentido da equidade, pois constrói uma solução equilibrada, sem agredir a lei ( . . . ) - g.n. - p. 448. "Pelo exposto, dá-se provimento ao recurso dos autores, julgando-se procedente a ação para que essa decisão sirva de título de registro de transferência do imóvel referido na inicial, substituindo a escritura pública que o requerido não outorgou livremente, ressalvando a ele a oportunidade de, por ação própria, executar eventual saldo do preço estipulado." (g.n. p. 454)" (grifo nosso). O art. 127 do Código de Processo Civil dispõe que "O juiz só decidirá por eqüidade nos casos previstos em lei". Documento: 1207397 - Inteiro Teor do Acórdão - Site certificado - DJe: 21/02/2013 Página 6 de 4 Superior Tribunal de Justiça Antes de mais nada, é oportuno esclarecer que o Código de Processo Civil, sancionado na vigência da Emenda Constitucional de 1969, consubstanciando valores e 
princípios diversos dos que legitimam a atual Constituição, é produto de uma concepção formal e legalista, possui menor afinidade com o espírito do novo Código Civil, de fundamentos essencialmente axiológicos. Atualmente é forçoso reconhecer que, em cada decisão judicial concreta, deve atuar o conteúdo global da ordem jurídica. Sob essa ótica, o Código de Processo Civil vigente e o novo Código Civil representam pensamentos jurídicos, histórica e filosoficamente diversos. O primeiro, normativo, orientado para a aplicação lógico-dedutiva das normas; o segundo, jurisprudencial, dispondo de princípios e cláusulas gerais, orientando o intérprete para a decisão jurídica de modo problemático-dialético, prevendo o recurso a critérios de marcante eticidade jurídica que permitam chegar à concreção jurídica, conferindo maior poder ao juiz para encontrar a solução mais justa ou eqüitativa, como se vê no caso dos autos. No caso em tela, o Tribunal de origem apenas sopesou o equilíbrio entre o direito do recorrido de ter o bem adjudicado e o direito do recorrente de cobrar eventuais resíduos. Nesse diapasão, não há que se falar em violação do dispositivo mencionado. Com efeito, o artigo 127 do Código de Processo Civil, apontado como violado, não constitui imperativo legal apto a desconstituir o fundamento declinado no acórdão recorrido no sentido de se admitir a ação do autor para garantir o domínio do imóvel próprio, reservando-se ao vendedor o direito de executar eventual saldo remanescente. 7.- Em relação à exceção do contrato não cumprido, o recorrente sustenta que (e-STJ fl. 572): "O disposto no artigo 476 do Código Civil reza que "nos contratos bilaterais, nenhum dos contratantes, antes de cumprida sua obrigação, pode exigir o implemento da do outro". Como se vê no caso vertente, os nobres Desembargadores do Egrégio Tribunal de Justiça de São Paulo, ignorando a aludida norma, bem como o laudo pericial (cálculos do contador) realizado que constatou o pagamento de menos de $50 \%$ (cinqüenta por cento) do estipulado contratualmente, solucionaram a lide com fundamento Documento: 1207397 - Inteiro Teor do Acórdão - Site certificado - DJe: 21/02/2013 Página 7 de 4 Superior Tribunal de Justiça na equidade, quando existe legislação aplicável à espécie. Como se vê, o acórdão proferido pela Quarta Câmara de Direito Privado do Egrégio Tribunal de Justiça do Estado de São Paulo viola expressamente os mencionados dispositivos legais, pois impôs ao recorrente a obrigação de outorga de escritura definitiva do imóvel, enquanto ainda não adimplida a obrigação, fato este comprovado através de laudo pericial que apurou o inadimplemento do preço, não chegando nem mesmo à metade do avençado no contrato de compromisso de 
compra e venda" No entanto, o Acórdão recorrido proclama que (e-STJ fl. 468): Embora não se permita declarar, com absoluta segurança, que o preço foi integralmente quitado, a boa-fé dos compromissários compradores é incontroversa, reveladora de que agiram, nos longos anos que marcaram cumprimento fiel das prestações, para que o contrato cumprisse sua função primordial. Realizaram-se os pagamentos e poderá ser afirmado que ocorreu cumprimento substancial do contrato. $\mathrm{O}$ adimplemento substancial é uma teoria que surgiu para evitar conseqüências drásticas [resolução] diante da insignificante impontualidade de um dos contratantes com suas obrigações. Portanto, se o comprador quitou quase que integralmente o preço do negócio, não poderia o inadimplemento de parte inexpressiva produzir um resultado enorme, como o fim da relação e retorno ao status quo ante. Admite-se que a outra parte continua com o direito preservado de obter a reparação por essa falta, permitindo que exerça essa pretensão pela forma menos onerosa ao ideal de preservação dos contratos. (grifo nosso). Verifica-se uma apenas aparente incompatibilidade entre dois institutos, a exceção do contrato não cumprido e o adimplemento substancial. No entanto, tais institutos coexistem perfeitamente, podendo ser identificados sem ofensa à segurança jurídica decorrente oriunda da autonomia privada. A doutrina do adimplemento substancial aplica-se, exatamente, na hipótese de pretensão do credor à resolução diante de situação em que ocorra a mora do devedor, caracterizada pelo adimplemento em desconformidade com o que foi contratado. Documento: 1207397 - Inteiro Teor do Acórdão - Site certificado - DJe: 21/02/2013 Página 8 de 4 Superior Tribunal de Justiça No caso dos autos, restou patente que a obrigação se definiu quanto ao número de OTNs a serem pagas pelo recorrido sem, no entanto, estipulação da quantidade de parcelas a serem pagas em favor do recorrente. Essa situação, por si só, afasta a incidência da exceção do contrato não cumprido diante da omissão contratual existente. $\mathrm{Na}$ hipótese, tratando-se de contrato de adesão, não resta dúvida de que a interpretação de favorecer o aderente. Mas a discussão não se exaure apenas com esse raciocínio. Observe-se que no adimplemento substancial tem-se uma evolução gradativa da noção de tipo de dever contratual descumprido, para uma verificação efetiva da gravidade do descumprimento, consideradas as consequiências que, da violação do ajuste, decorre para a finalidade do contrato. Nessa linha de pensamento, há que observar dois critérios que embasam o acolhimento do adimplemento substancial: a seriedade das consequiências que de fato resultaram do descumprimento, e a importância que as partes 
aparentaram dar à cláusula pretensamente infringida. Veja-se que o desenvolvimento da teoria em referência teve por escopo permitir que uma das partes contratuais não se beneficiasse de tímida aparência de descumprimento contratual por parte da outra, servindo assim a teoria a obstar o enriquecimento ilícito. Assim, considera-se acertada a tese do Acórdão impugnado, ao conciliar o direito do recorrente e a obrigação dos recorridos, de modo a afastar a alegação de locupletamento ilícito. Portanto, não se vislumbra, no caso, violação dos 476, 884, 885 do Código Civil. Vale lembrar que, tal posicionamento encontra respaldo na própria jurisprudência desta Corte exposto em recente proferido pela Quarta Turma. Vejamos: DIREITO CIVIL. CONTRATO DE ARRENDAMENTO MERCANTIL PARA AQUISIÇÃO DE VEÍCULO (LEASING). PAGAMENTO DE TRINTA E UMA DAS TRINTA E SEIS PARCELAS DEVIDAS. RESOLUÇÃO DO CONTRATO. AÇÃO Documento: 1207397 - Inteiro Teor do Acórdão - Site certificado - DJe: 21/02/2013 Página 9 de 4 Superior Tribunal de Justiça DE REINTEGRAÇÃO DE POSSE. DESCABIMENTO. MEDIDAS DESPROPORCIONAIS DIANTE DO DÉBITO REMANESCENTE. APLICAÇÃO DA TEORIA DO ADIMPLEMENTO SUBSTANCIAL. 1. É pela lente das cláusulas gerais previstas no Código Civil de 2002, sobretudo a da boa-fé objetiva e da função social, que deve ser lido o art. 475, segundo o qual "[a] parte lesada pelo inadimplemento pode pedir a resolução do contrato, se não preferir exigir-lhe o cumprimento, cabendo, em qualquer dos casos, indenização por perdas e danos". 2. Nessa linha de entendimento, a teoria do substancial adimplemento visa a impedir o uso desequilibrado do direito de resolução por parte do credor, preterindo desfazimentos desnecessários em prol da preservação da avença, com vistas à realização dos princípios da boa-fé e da função social do contrato. 3. No caso em apreço, é de se aplicar a da teoria do adimplemento substancial dos contratos, porquanto o réu pagou: "31 das 36 prestações contratadas, $86 \%$ da obrigação total (contraprestação e VRG parcelado) e mais R $\$ 10.500,44$ de valor residual garantido". O mencionado descumprimento contratual é inapto a ensejar a reintegração de posse pretendida e, consequentemente, a resolução do contrato de arrendamento mercantil, medidas desproporcionais diante do substancial adimplemento da avença. 4. Não se está a afirmar que a dívida não paga desaparece, o que seria um convite a toda sorte de fraudes. Apenas se afirma que o meio de realização do crédito por que optou a instituição financeira não se mostra consentâneo com a extensão do inadimplemento e, de resto, com os ventos do Código 
Civil de 2002. Pode, certamente, o credor valer-se de meios menos gravosos e proporcionalmente mais adequados à persecução do crédito remanescente, como, por exemplo, a execução do título. 5. Recurso especial não conhecido. (REsp 1051270/RS, Rel. Ministro LUIS FELIPE SALOMÃO, QUARTA TURMA, julgado em 04/08/2011, DJe 05/09/2011) 8.- No tocante a impossibilidade de adjudicação compulsória e ausência de provas constitutivas do direito do autor, o recorrente aduziu que: "Da leitura desse dispositivo extrai-se que os compromissários compradores, desde que comprovem que ultimaram o pagamento integral do preço, passam a ter o direito à outorga da escritura definitiva de compra e venda. Ocorre que, in casu, os recorridos não pagaram nem mesmo a. metade do preço acordado, como já explicitado e, inclusive reconhecido nos v. arestos, com a ressalva da possibilidade do recorrente ingressar com ação para cobrança do saldo devedor. Patente a violação do dispositivo infraconstitucional acima mencionado (e-STJ fl.580)." Quanto ao ponto, entretanto o Acórdão mencionou que:"A perícia - leia-se cálculos do contador judicial -, não cumpriu, nessa parte, a sua missão de esclarecer o Juízo se a correção monetária serviu para reconstruir a moeda defasada ou não, o que compromete a função da cláusula. A escolha das OTN'S estimulou uma dúvida de ter sido ou não quitado o preço e não basta afirmar, como fez o perito, que os pagamentos não completam o número de OTN'S, exatamente porque o encontro das cifras, na exatidão matemática, não é, agora, o mais importante. $\mathrm{O}$ fato é que as partes vivem uma expectativa, diante de tal indefinição e dependem do Judiciário para resolução do conflito imposto pelo pagamento das 144 prestações, que foram recebidas com ressalva de exigibilidade do saldo. O que fazer? (e-STJ fl. 465)". Nesse passo, cabe enfatizar que o entendimento adotado pelo Tribunal de origem baseou-se na análise do conjunto probatório existente nos autos. Rever tal entendimento, obviamente, demandaria revolvimento dessas provas, o que é inviável em sede de recurso especial, a teor do disposto na Súmula 07/STJ, assim redigida: "A pretensão de simples reexame de prova não enseja recurso especial." Nesse sentido, já se firmou a jurisprudência deste Superior Tribunal de Justiça: "Evidenciado que o acórdão recorrido decidiu a controvérsia, tão-somente, por meio do exame acurado das provas coligidas ao processado, evidencia-se imprópria a utilização do recurso especial, em face do óbice manifesto pela Súmula n. 07/STJ" (1 ${ }^{\text {a }}$ Turma, AgR-REsp n. 652.295/RS, Rel. Min. José Delgado, unânime, DJU de $1^{\circ}$.2.2005).” 9.- Finalmente, no tocante à admissibilidade do recurso especial pela alínea Documento: 1207397 - Inteiro Teor do Acórdão - Site 
certificado - DJe: 21/02/2013 Página 11 de 4 Superior Tribunal de Justiça "c", esta Corte tem decidido, iterativamente, que, para a comprovação e apreciação da divergência jurisprudencial, devem ser mencionadas e expostas as circunstâncias que identificam ou assemelham os casos confrontados, bem como juntadas cópias integrais dos julgados trazidos ou citado repositório oficial de jurisprudência. Nesse sentido, já se firmou a jurisprudência deste Superior Tribunal: "PROCESSO CIVIL - AGRAVO DE INSTRUMENTO - NEGATIVA DE PROVIMENTO - AGRAVO REGIMENTAL EMBARGOS À EXECUÇÃO - DIVERGÊNCIA JURISPRUDENCIAL - AUSÊNCIA DE CONFRONTO ANALÍTICO - ART. 585, VII, DO CPC - NEGATIVA DE VIGÊNCIA - REEXAME DE PROVA - SÚMULA 7/STJ - DESPROVIMENTO. 1 Esta Corte, reiteradamente, tem decidido que, a teor do art. 255 e parágrafos, do RISTJ, para a comprovação e apreciação da divergência jurisprudencial, devem ser mencionadas e expostas as circunstâncias que identificam ou assemelham os casos confrontados, bem como juntadas cópias integrais de tais julgados ou, ainda, citado repositório oficial de jurisprudência. 'In casu', a agravante limitou-se em transcrever ementas e grifá-las, deixando de demonstrar a similitude fática dos casos, bem como o devido cotejo analítico entre os vv. arestos, ao não especificar claramente os fatos e circunstâncias que identificam ou assemelham os casos confrontados. 2 - (...) 3 - Agravo regimental desprovido." (AgRg no Ag 714155/RS; Relator Ministro Jorge Scartezzini, DJ 20.02.2006)". Referido óbice também impede a apreciação da divergência jurisprudencial suscitada, uma vez que não restou demonstrada a perfeita similitude fática entre o acórdão impugnado e os paradigmas colacionados. 10. Diante do exposto, nega-se provimento ao Recurso Especial mantendo-se, por consequiência, totalmente, o Acórdão recorrido. Ministro SIDNEI BENETI Relator Documento: 1207397 - Inteiro Teor do Acórdão - Site certificado - DJe: 21/02/2013 Página 12 de 4 Superior Tribunal de Justiça CERTIDÃO DE JULGAMENTO TERCEIRA TURMA Número Registro: 2010/0177513-3 PROCESSO ELETRÔNICO REsp 1.215.289 / SP Números Origem: $\begin{array}{llllll}13040014 & 3040012001 & 37944042 & 3794404200 & 3794404602 & 994050122396\end{array}$ 99405012239650002 PAUTA: 05/02/2013 JULGADO: 05/02/2013 Relator Exmo. Sr. Ministro SIDNEI BENETI Presidente da Sessão Exmo. Sr. Ministro PAULO DE TARSO SANSEVERINO Subprocurador-Geral da República Exmo. Sr. Dr. JOSÉ BONIFÁCIO BORGES DE ANDRADA Secretária Bela. MARIA AUXILIADORA RAMALHO DA ROCHA AUTUAÇÃO RECORRENTE: HUGO ENEAS 
SALOMONE ADVOGADO : SABRINA BERARDOCCO CARBONE E OUTRO(S)

RECORRIDO : ANITO GONÇALVES E OUTRO ADVOGADO : MARCIA APARECIDA DA SILVA ANNUNCIATO E OUTRO(S) ASSUNTO: DIREITO CIVIL - Obrigações - Espécies de Contratos - Compra e Venda CERTIDÃO Certifico que a egrégia TERCEIRA TURMA, ao apreciar o processo em epígrafe na sessão realizada nesta data, proferiu a seguinte decisão: A Turma, por unanimidade, negou provimento ao recurso especial, nos termos do voto do(a) $\operatorname{Sr}($ a). Ministro(a) Relator(a). Os Srs. Ministros Paulo de Tarso Sanseverino, Ricardo Villas Bôas Cueva e Nancy Andrighi votaram com o Sr. Ministro Relator. 
Enunciado 361 da IV Jornada de Direito Civil do CJF em 2006.

“Arts. 421, 422 e 475. O adimplemento substancial decorre dos princípios geraqis contratuais, de modo a fazer preponderar a função social do contrato e o princípio da boa-fé objeiva, balizando a aplicação do art. 475." 


\section{Cases do sistema do Common Law.}

Vide in CRUISE, Willian. Digest of the Laws of England Respecting Real Property, volume II, $3^{\text {a }}$ edition, pág. 34.

\section{Case original: Boone v. Eyre.}

“(a) Boone v. Eyre, B. R. East. 17 Geo. 3”. [See S. C. 2 W. Bl. 1312; 96 E. R. 767 (with note), to which add General Billposting Company v. Atkinson, [1909] A. C. 121]. Covenant on a deed, whereby the plaintiff conveyed to the defendant the equity of redemption of a plantation in the West Indies, together with the stock of negroes upon it, in consideration of $500 \mathrm{l}$. and an annuity of $160 \mathrm{l}$. per annum for his life; and covenanted that he had a good title to the plantation, was lawfully possessed of the negroes and that the defendant should quietly enjoy. The defendant covenanted, that the plaintiff well and truly performing all and every thing therein contained on his part to be performed, he the defendant would pay the annuity. The breach assigned was the non-payment of the annuity. Plea, that the plaintiff was not, at the time of making the deed, legally possessed of the negroes on the plantation, and so had not good title to convey. To which there was a general demurrer. LORD MANSFIELD - The distinction is very clear, where mutual covenants go to the whole of the consideration on both sides, they are mutual conditions, the one precedent to the other. But where they go only to a part, where a breach may be paid for in damages, there the defendant has a remedy on his covenant, and shall not plead it as condition precedent. If this plea were to be allowed, any one negro not being the property of the plaintiff would bar the action. Judgment for the plaintiff." 


\section{Case: Dunlop v. Selfridge}

Vide também in MAJOR, W. T. Cases in Contract Law, 1972, págs. 62 a 64.

Dunlop, uma empresa de fabricação de pneus, fez um contrato com Dew, um comprador de mercadorias, para aquisição de pneus a um preço com desconto na condição de que ele não iria revender os pneus por menos do que o preço tabelado e que qualquer revendedor que quisesse comprá-los de Dew teria que concordar também em não vender a um preço mais baixo. Dew vendeu os pneus para Selfridge ao preço tabelado e fez Selfridge concordar em não vender também a um preço inferior e que ele iria pagar $£ 5$ em danos se ele violasse este acordo. Selfridge começou a vender os pneus abaixo do preço pelos quais ele prometeu vendê-los. Dunlop ajuizou uma ação e foi bem sucedido em julgamento de primeira instância, mas esta foi revertida pela Corte de Apelação. Nessa decisão, que embora trate igualmente do chamado princípio da relatividade dos contratos, também abordou a consideration da seguinte maneira: a doutrina da consideration exigiria que o compromissário (Dunlop) levasse em consideração a posição de Selfridge para o contrato ser concluído, e isso não ocorreu visto que Dunlop não deu nada a Selfridge aqui (Selfridge fez uma promessa a Dunlop de apenas vender até certo preço, mas isso era um ato gratuito dele [ato sem razão], porque Dunlop não deu nenhuma consideração em resposta a essa questão). 
Case: $\underline{\text { Hoenig v. Isaacs }}$

BAILII Citation Number: [1952] EWCA Civ 6

Royal Courts of Justice

$13^{\text {th }}$ February 1952.

IN THE SUPREME COURT OF JUDICATURE. COURT OF APPEAL

B e f ore:

LORD JUSTICE SOMERVELL, LORD JUSTICE DENNING

and

LORD JUSTICE ROMER

Between: Hoenig v. Isaacs

Transcript of the Shorthand Notes of The Association of Official Shorthandwriters, Ltd., Room 392, Royal Courts of Justice, and 2, New Square, Lincoln's Inn, London, W.C.2.)

MR R J. PLATTS-MILLS and MR L.J.3BLCOURT (instructed by Messrs Beach \& Beach) appeared on behalf of the Appellant (Defendant MR NEIL LAWSON (instructed by Messrs Oppenheimer, Nathan \& Vandyk) appeared on behalf of the Respondent (Plaintiff).

LORD JUSTICE SOMERVELL: This is an appeal from an Official Referee, His Honour Sir Lionel Leach. The appellant must therefore satisfy us that the decision is wrong in law. The claim was for $£ 350$ as the balance due for work and labour and materials and goods supplied. The contract was for the redecoration and refurnishing of a small one room flat. There was and is some dispute as to the terms of the contract and where they are to be found, but its main provisions are clear. The plaintiff is an interior decorator and designer of furniture. The defendant desired to have his one room flat 
decorated and furnished in an ornate style. It was intended to result clearly in a single harmonious whole. The walls were to be repainted, certain electrical work was to be done, but the main items were furnishings, a curtain, a carpet, a divan cover, a settee of four movable chairs, a bedstead fitment, a wall fitment, a bookcase fitment, a combined writing table and cocktail cupboard and other minor items. The terms of payment were "net cash as the work proceeds, balance on completion." The negotiations began in March, 1950. On the 12th April, 1950, the defendant paid $£ 150$ and a further sum of $£ 150$ on the 19 th when he and the defendant met. A sum of $£ 750$ was agreed for the work. The work had not started but these payments indicate that the parties were or thought they were ad idem at the latter date. A plan was prepared to scale showing the layout of the various items and was discussed at the meeting between the plaintiff and defendant on the 19th April. On the 25th April the plaintiff sent to the defendant two documents. The first set out in some detail the various items which on the plaintiff's view were to be included in the order placed and as shown on the plan for the £750. The other document set out in the same way further items which were admittedly discussed on the 19th. The estimate for them was about $£ 100$. The plaintiff regarded them as extras not included in the $£ 750$. The defendant at once objected that these items were to be included. He at one time demanded the return of the $£ 300$. The defendant without, as I understand it, withdrawing his contention which was never accepted by the plaintiff told the plaintiff to proceed. The work was done and furnishings installed by the 15 th July. The defendant made a number of complaints. Some of these were attended to. On the 28th August the plaintiff chimed the balance of $£ 450$. The defendant replied complaining in general terms of omissions, faulty design and bad workmanship. He enclosed a further sum of $£ 100$. He said he proposed to call in a firm of good repute and get their estimate of what was required to complete what on his view were the defendant's obligations, which he proposed to deduct. He did not pursue this latter course. The furnishings remained in the flat and were used. The writ was issued on the 22nd November. The defence denied that the defendant was indebted to the plaintiff in the sum claimed or any sum. The first specific point taken was that the contract for $£ 750$ included what I have called the extras. The learned Official Referee referred to that as one of the main issues in the case before him. He decided that the work to be done for the $£ 750$ did not include these extras. On that point there is no appeal. 
The defence proceeded on the basis that the plaintiff had failed to perform his obligations. It was alleged that the defendant relied on the plaintiff's skill and judgment, and an implied term based on this is set out. It was alleged that the plaintiff had failed to perform his contract and this as I read it is put forward as a defence to the whole claim. Alternatively it is alleged that the work was done negligently, unskilfully and in an unworkmanlike manner and reference is made to particulars already delivered. There was a subsidiary claim for negligence which does not now arise and a counterclaim for damages.

Particulars were ordered and given and when the case was transferred to the Official Referee a Scott Schedule was ordered.

The learned Official Referee found that there had been a failure to perform the contract with regard to certain of the items as set out in the Scott Schedule. He held that the defendant was liable for the sum of $£ 750$ less the cost of remedying the defects due to breaches of the contract as the Official Referee construed it. He allowed a deduction on this basis of $£ 55.18 \mathrm{~s} .2 \mathrm{~d}$.

Mr Platts-Mills submits that is wrong in law. He submits that this is an entire contract which on the findings of fact has not been performed. On the well-known principle applied to the facts of that case in Cutter v. Powell, ((1795) 6 Term Reports, 320), he submitted that the plaintiff cannot therefore recover on his contract. He was not concerned to dispute that on this basis the plaintiff might on the facts of this case be entitled to recover on a quantum meruit. Such a claim has never been put forward. If it were he submits that the amount recoverable would be the fair value of what was done and delivered.

The learned Official Referee found that there had been a substantial compliance with the contract. Mr Platts-Mills submits that if his first point is right this does not enable the plaintiff to succeed. If necessary he submits that on his findings of fact the learned Official Referee was wrong as a matter of law in holding that there had been substantial compliance. 
Before considering the legal issues I will summarise the effect of the learned Official Referee's findings on the major items of complaint. He found there was a twist of the door of the wardrobe which justified the defendant in requiring a new door. There was evidence which the learned Official Referee accepted that the cost of replacing the door would be $£ 15$. The new door in order not to twist had on the findings to have the veneer set at an angle. This would put the veneer on the inside of the door out of line with the veneer in the interior of the wardrobe. This would be obvious when the door was open and was described as unsightly by a witness for the plaintiff. The door as originally designed was on the evidence as accepted bound to twist.

The other important item was a bookshelf which owing to faulty measurements taken by those for whom the plaintiff is responsible was $2 \frac{1}{2}$ ins. too short. It was to join on to the wardrobe and as fitted had at the end what was called a scribing piece. The plaintiff and his witnesses came badly out of this transaction. They sought at different times to say that the scribing piece was in accordance with the plan; that the Defendant had misled them as to the measurements; that the scribing piece was necessary. All these were rejected. The faulty measurements also resulted in a hook-case at the other end being as originally constructed too large. It was cut down with the result that what was intended as a diamond pattern on some leather on a door was not a diamond pattern. The learned Official Referee held that the bookshelf must be remade and he accepted evidence that this would cost $£ 29.6 \mathrm{~s}$.8d. The bookcase he held could be remedied by having the leather work replaced and he found the cost of this to be $£ 4$.

Mr Platts-Mills sought to argue that some of the other matters though small in amount were substantial in their nature. I do not agree with this. If any issue arises as to whether the breaches were substantial, I think it must be based on the items to which I have referred, bearing in mind, of course, that there were some additional minor defects.

The Official Referee regarded the principle laid down in Dakin \& Co., Ltd. v. Lee, (1916, 1 King's Bench, page 566) as applicable. The contract in that case was for repairs to a house. The Official Referee before whom the case came in the first instance found that the work as completed did not accord with the contract in certain respects. He proceeded to hold that the plaintiff could not recover any part of the contract price or 
any sum in respect of the contract work. This decision was reversed in the Divisional Court and their decision was affirmed by this Court. In support of the Official Referee's decision it was argued that the plaintiff could not recover either on the contract or on a quantum meruit. No new contract on the latter basis could be implied from the fact that the defendant by continuing to live in her house had enjoyed the benefit of what had been done.

In Eshelby v. Federated European Bank Ltd. (1932, 1 King's Bench, page 423,) at page 431 Lord Justice Greer clearly felt some difficulty about Dakin v. Lee as possibly inconsistent with Cutter v. Powell (6 Term Reports, page 320) and the cases following that decision as deciding that where work is to be done for a sum named neither that sum nor any part of it can be recovered while the work remains undone. We were referred to a number of these cases and I have considered those cases and others. Each case turns on the construction of the contract. In Cutter v. Powell the condition for the promissory note sued on was that the sailor should proceed to continue and do his duty as second mate, in the ship from Jamaica to the port of Liverpool. The sailor died before the ship reached Liverpool and it was held his estate could not recover either on the contract or on a quantum meruit. It clearly decided that his continuing as mate during the whole voyage was a condition precedent to payment. It did not decide that if he had completed the main purpose of the contract, namely, serving as mate for the whole voyage, the defendant could have repudiated his liability by establishing that in the course of the voyage the sailor had, possibly through inadventence, failed on some occasion in his duty as mate whereby some damage had been caused. In these circumstances, the Court might have applied the principle applied to ordinary contracts for freight. The shipowner can normally recover nothing unless the goods are carried to their agreed destination. On the other hand, if this is done, his claim is not defeated by the fact that some damage has been done to the goods in transit which had resulted from a breach of the contract. The owner of the goods had his remedy by cross action (Dakin v. Oxley, 15 Common Bench Reports, New Series, page 646). The damage might, of course, be so great as to raise the question whether what was agreed to be carried had substantially arrived (ibid). Sinclair v. Bowles (9 Barnewall and Cresswell, page 92) is often cited as an illustration of the Cutter v. Powell principle. The plaintiff had undertaken to repair chandeliers and make them "complete" or "perfect". This he quite 
plainly on the evidence and findings of the jury failed to do. It may perhaps be regarded as a case where on the construction of the contract having regard to the subject-matter there was no scope for terms collateral to the main purpose.

The principle that fulfilment of every term is not necessarily a condition precedent in a contract for a lump sum is usually traced back to a short judgment of Lord Mansfield in Boone v. Eyre (1 Hy.Bl. 273 n.) - the sale of the plantation with its slaves. Lord Mansfield said this:

"Where the mutual covenants go to the whole of the consideration on both sides they are mutual conditions the one precedent to the other. But where they go only to a part, where a breach may be paid for in damages, then the defendant has a remedy for his covenant and shall not plead it as a condition precedent".

One is very familiar with the application of this principle in the law relating to the sale of goods. Quoad stipulations which are conditions, the $\underline{\text { Cutter }}$ and Powell other party can repudiate, but there will not have been, as there was in Cutter v. Powell, a partial performance. But there may be other terms, collateral to the main purpose the breach of which in English law gives rise to a claim for damages, but not to a right to reject the goods and treat the contract as repudiated. (See definition of warranty, Sale of Goods Act, section 62).

In a contract to erect buildings on the defendant's land for a lump sum, the builder can recover nothing on the contract if he stops before the work is completed in the ordinary sense, in other words abandons the contract. He is also usually in a difficulty in recovering on a quantum meruit because no new contract can be inferred from the mere fact that the defendant remains in possession of his land (Sumpter v. Hedges, 1898, 1 Queen's Bench, page 673). In Appleby v. Myers (Law Reports, 2 Common Pleas, page 651) while the work was in progress the premises and the work so far done on them were destroyed by fire and the Court held both parties excused. At the end of his judgment Mr Justice Blackburn, after referring to Cutter v. Powell, Sinclair v. Bowles (9 Barnewall and Cresswell, page 92) and that line of cases, said: 
"The plaintiffs having contracted to do an entire work for a specific sum recover nothing unless the work be done."

In Dakin v. Lee Lord Cozens-Hardy I think had this principle in mind when he said:

"The work was finished - and when I say this I do not wish to prejudice matters, but I cannot think of a better word at the moment."

The question here is whether in a contract for work and labour for a lump sum payable on completion the defendant can repudiate liability under the contract on the ground that the work though "finished" or "done" is in some respects not in accordance with the contract. Dakin v. Lee is, of course, binding on us, but Mr Platts-Mills submitted that it was an exception to a general rule applying to contracts such as that in issue here and should be confined within as narrow limits as possible. I agree with the learned editor of the notes to Cutter v. Powell in Smith's Leading Cases, Volume 11, 13th Edition, page 21, that Dakin v. Lee so far from being an exception reaffirmed the true position on the construction of this class of contract on which doubts had been thrown by taking certain observations out of their context.

In Broom v. Davis (7 East, page 481) Mr Justice Buller decided that where a man had contracted to build a booth for a lump sum, and the booth was built but later fell down through faulty workmanship the plaintiff could claim the agreed sum, but the defendant could have a cross action for damages. So far as one can gather the facts from the report it might I think be held today that the defects were so substantial as to go to the root of the consideration, but it is an example, perhaps an extreme one, of the principle applied in Dakin v. Lee.

In Mondel v. Steel (8 Meeson and Welsby, page 858) the issue was procedural, but in a passage often cited Baron Parke deals with contracts "for an agreed price for work which was to be done according to contract." After referring to the fact that a breach of warranty does not preclude the buyer from maintaining an action for the price he says of an agreement for work at page 870 : 
"the law appears to have construed the contract as not importing that the performance of every part of the work should be a condition precedent to the payment of the stipulated price, otherwise the least deviation would have deprived the plaintiff of the whole price and therefore the defendant was obliged to pay it and recover for any breach of contract on the other side."

The learned Official Referee regarded Dakin v. Lee as laying down that the price must be paid subject to set off or counterclaim if there was a substantial compliance with the contract. I think on the facts of this case where the work was finished in the ordinary sense though in part defective this is right. It expresses in a convenient epithet what is put from another angle in the Sale of Goods Act. The buyer cannot reject if he proves only the breach of a term collateral to the main purpose.

I have therefore come to the conclusion that Mr Platts-Mills' first point falls. The learned Official Referee found that there was substantial compliance. Bearing in mind that there is no appeal on fact, was there evidence on which he could so find?

It is necessary here to consider a ruling given by the learned Official Referee that the defendant having approved the plan was not entitled to damages on the ground of faulty design. The question of design is, he said, not open. The ruling was given at the close of the plaintiff's case and was coupled with a ruling that the contract had been reduced to writing on the plan and specification subject to the question whether extra items were included in the $£ 750$. Mr Platts-Mills criticised these rulings and the time at which they were given. The word "design" may have more than one sense. It seems to me that on the evidence as given and accepted the learned Official Referee was entitled to rule that the defendant had accepted the general lay-out as shown by the plan. If he had intended to shut out evidence that the furniture as designed, or as delivered, was faulty though in accordance with the plan, he would have been wrong. It seems to me clear that he did not seek to do this as is shown by his findings as to the wardrobe door to which I have referred and other items.

With regard to the contract, it is material to consider the defence. The agreement is there alleged as concluded orally on the 19th April in terms which the defendant was saying 
covered the extras. This point was clearly kept open by the Official Referee. There was an allegation that the defendant relied on the plaintiff's skill and judgment as an expert furniture designer. Subject to the approval of the lay-out as shown on the plan I think the learned Official Referee was accepting this. An implied term based on this is set out. That is not therefore based on any express oral term. One turns to the particulars and the Scott Schedule and, reading them with the judgment, I cannot myself detect any error of law. If the defendant desired to come to this Court on the point that the ruling excluded relevant evidence I think the proper course would have been to ask the question, and if the Official Referee ruled it was inadmissible to ask him to take a note of Counsel's submission that it was wrongly excluded.

I come back to the finding that there was substantial compliance. The learned Official Referee having, as I hold, properly directed himself, this becomes, I think, a question of fact. The case on this point was, I think, near the border line, and if the finding had been the other way I do not think we could have interfered.

Even if I had felt we could interfere, the defendant would be in a further difficulty. The contract included a number of chattels. If the defendant wished to repudiate his liability under the contract he should not, I think, have used those articles, which he could have avoided using. On this view, though it is not necessary to decide it, I think he put himself in the same position as a buyer of goods who by accepting them elects to treat a breach of condition as a breach of warranty, I now come to the final question, the measure of damages. It seems from the argument that the defendant regards the price of $£ 750$ as excessive irrespective of any relief by way of reduction of price or on his counterclaim. He was anxious to put the plaintiff in the position of having to sue on a quantum meruit for the value of the work done and he was anxious to tender evidence designed no doubt to show that the work done was worth much less than $£ 750$. The learned Official Referee excluded this evidence. The measure he applied was the cost of putting the work in accordance with the contract and on this basis such evidence was rightly excluded. The defendant is bound, he held, to pay for the furniture supplied less the cost of putting right the defects. This I think is, as the learned Official Referee thought, in accordance with Dakin v. Lee. Lord Cozens-Hardy there said: 
"the builders are entitled to recover the contract price, less so much as it is found ought to be allowed in respect of the items which the Official Referee has found to be defective".

This seems to follow what was said by Baron Parke in Mondel v. Steel (at pages 871-2). In dealing with the procedural point he said that the defendant need not bring a cross action but can diminish the price "by showing how much less the subject-matter of the contract was worth by reason of the breach of contract".

Mr Platts-Mills finally submitted that on the figures the Official Referee in certain cases took a manufacturer's price instead of a dealer's price. On examining the notes of evidence I do not think there is anything in this point. Nor on any view do I think it would be open in this case in this Court.

I therefore think the appeal must be dismissed.

LORD JUSTICE DENNING: This case raises the familiar question: Was entire performance a condition precedent to payment? That depends on the true construction of the contract.

In this case the contract was made over a period of time and was partly oral and partly in writing, but I agree with the Official Referee that the essential terms were set down in the letter of 25th April, 1950. It describes the work which was to be done and concludes with these words:

"The foregoing, complete, for the sum of $£ 750$ nett. Terms of payment are nett cash, as the work proceeds; and balance on completion."

The defendant paid $£ 150$ on 12th April, 1950, and another $£ 150$ on the 19th April, 1950. On 8th August, 1950, the plaintiffs said that they had carried out the work in absolute compliance with the contract and demanded payment of the balance of $£ 450$. On the 30th August, 1950, the defendant paid $£ 100$, but said that there were defects and omissions in the work and that he would call in someone else to make them good and 
deduct the cost from the plaintiffs' bill. He did not do this but entered into occupation of the flat and used the furniture. The plaintiffs then brought this action for the balance of $£ 350$. They denied that there were any defects at all. The Official Referee found that there were defects in three of the items of furniture and that the cost of remedying them was $£ 55.18 \mathrm{~s} .2 \mathrm{~d}$. He deducted that sum from the $£ 350$ and gave judgment for the plaintiffs for $£ 294.1$ s.10d.

The question of law that was debated before us was whether the plaintiffs were entitled in this action to sue for the $£ 350$ balance of the contract price as they had done. The defendant said that they were only entitled to sue on a quantum meruit. The defendant was anxious to insist upon a quantum meruit, because he said that the contract price was unreasonably high. He wished therefore to reject that price altogether and to pay simply a reasonable price for all the work that was done. This would obviously mean an inquiry into the value of every item, including all the many items which were in compliance with the contract as well as the three which fell short of it. That is what the defendant wanted. The plaintiffs resisted this course and refused therefore to claim on a quantum meruit. They said that they were entitled to the balance of $£ 350$ less a deduction for the defects.

In determining this issue the first question is whether, on the true construction of the contract, entire performance was a condition precedent to payment. It was a lump sum contract, but that does not mean that entire performance was a condition precedent to payment.

When a contract provides for a specific sum to be paid on completion of specified work, the Courts lean against a construction of the contract which would deprive the contractor of any payment at all simply because there are some defects or omissions. The promise to complete the work is therefore construed as a term of the contract, but not as a condition. It is not every breach of that term which absolves the employer from his promise to pay the price, but only a breach which goes to the root of the contract, such as an abandonment of the work when it is only half done. Unless the breach does go to the root of the matter, the employer cannot resist payment of the price. He must pay it and bring a cross-claim for the defects and omissions, or alternatively set them up 
in diminution of the price. The measure is the amount which the work is worth less by reason of the defects and omissions, and is usually calculated by the cost of making them good; see Mondel v.Steel ((1841) 8 Meeson \& Welsby, page 858); $\underline{\text { H. Dakin \& }}$ Co. Ld. v. Lee (1916, 1 King's Bench, page 566), and the notes to Cutter v. Powell in the 13th Edition of Smith's Leading Cases II., 19-21.

It is, of course, always open to the parties by express words to make entire performance a condition precedent. A familiar instance is when the contract provides for progress payments to be made as the work proceeds, but for retention money to be held until completion. Then entire performance is usually a condition precedent to payment of the retention money, but not, of course, to the progress payments. The contractor is entitled to payment pro rata as the work proceeds, less a deduction for retention money: but he is not entitled to the retention money until the work is entirely finished, without defects or omissions.

In this case the contract provided for "nett cash as the work proceeds and balance on completion." If the balance could be regarded as retention money, then it might well be that the contractor ought to have done all the work correctly, without defects or omissions, in order to be entitled to the balance. But I do not think the balance should be regarded as retention money. Retention money is usually only 10 per cent, or 15 per cent, whereas this balance was more than 50 per cent. I think this contract should be regarded as an ordinary lump sum contract. It was substantially performed. The contractor is entitled therefore to the contract price, less a deduction for the defects.

Even if entire performance was a condition precedent, nevertheless the result would be the same; because I think the condition was waived. It is always open to a party to waive a condition which is inserted for his benefit. What amounts to a waiver depends on the circumstances. If this was an entire contract, then when the plaintiff tendered the work to the defendant as being a fulfilment of the contract, the defendant could have refused to accept it until the defects were made good, in which case he would not have been liable for the balance of the price until they were made good. But he did not refuse to accept the work. On the contrary, he entered into possession of the flat and used the furniture as his own, including the defective items. That was a clear waiver of the condition precedent. Just as in a sale of goods, the buyer, who accepts the goods, can no 
longer treat a breach of condition as giving a right to reject but only a right to damages: so also in a contract for work and labour, an employer who takes the benefit of the work can no longer treat entire performance as a condition precedent, but only as a term giving rise to damages. The case becomes then an ordinary lump sum contract governed by the principles laid down in Mondel v. Steel and Dakin v. Lee. The employer must therefore pay the contract price subject to a deduction for defects or omissions.

I would point out that in these cases the question of quantum meruit only arises when there is a breach or failure of performance which goes to the very root of the matter. On any lump sum contract, if the work is not substantially performed and there has been a failure of performance which goes to the root of it, as, for instance, when the work has only been half done, or is entirely different in kind from that contracted for, then no action will lie for the lump sum. The contractor can then only succeed in getting paid for what he has done if it was the employer's fault that the work was incomplete; or there is something to justify the conclusion that the parties have entered into a fresh contract: or the failure of performance is due to impossibility or frustration, see Appleby v. Myers. (Law Reports, 2 Common Pleas, page 651, at page 660) and Sumpter v. Hedges (1898, 1 Queen's Bench, page 673), and section 1 (3) of the Frustrated Contracts Act, 1943. In such cases the contractor can recover in an action for restitution such sum as he deserves, or in the words of the Act, "such sum as the Court considers just." Those cases do not, however, apply in this case, because in this case the work has been substantially performed.

In my opinion the Official Referee was right and this appeal should be dismissed.

LORD JUSTICE ROMER: I agree that this appeal fails.

By the contract between the parties in this case the Plaintiff undertook to decorate and furnish a small bed-sitting room which the Defendant occupied. The work comprised the provision of a number of pieces of furniture and various fittings, the washing down and repainting of the walls, ceiling and woodwork and the carrying out of electrical work for the electrical fitments provided. The price agreed was to be an all-in sum of $£ 750$ and the terms of payment were described as "nett cash, as the work proceeds, and 
balance on completion." The contract was, accordingly, a "lump sum" contract. In due course the Plaintiff provided articles of furniture of the nature and character that he had contracted to provide and carried out the agreed re-decoration of the ceiling and walls. The Defendant, by instalments, paid $£ 400$ of the agreed price and kept the furniture but, when sued for the balance, refused to pay any more and said, indeed, and argued before us that he was not in law liable to pay anything under the contract at all because of certain defects in the furniture. The ground upon which he based this claim was that the contract was an entire contract, that the Plaintiff could not sue for any part of the purchase price unless and until he had wholly performed his obligations thereunder and that this was a condition precedent which had never been fulfilled. Inasmuch as the learned Official Referee who tried the case found that notwithstanding the most searching investigation by the Defendant into every possible source of complaint a sum of $£ 55.18 \mathrm{~s} .2 \mathrm{~d}$. only was required to put right such defects in the work as he (the Referee) found to have been established, the Defendant's contention would appear on the face of it to be somewhat harsh; and it is to be observed that the contention could have been similarly used had the remedial expenditure amounted to no more than a $£ 5$ note.

The Defendant's only attack on the Plaintiff's performance of his obligations was in relation to certain articles of furniture which the Plaintiff supplied and which the Defendant says were faulty and defective in various important respects. The finding of the learned Official Referee on this was "that the furniture supplied constituted a substantial compliance with the contract so far as the supply of furniture was concerned." That is a finding of fact and whether or not another mind might have taken a different view it appears to me impossible to say that there was no sufficient evidence upon which the finding could be based. This, then, being a lump sum contract for the supply of furniture (and the carrying out of certain minor work) which was substantially complied with by the Plaintiff, the question is whether the Official Referee was wrong in law in applying the principle of $\underline{H}$. Dakin \& Co. Ltd. v. Lee and rejecting the Defendant's submission that the Plaintiff had failed to perform a condition upon the fulfilment of which his right to sue depended. In my judgment he was quite right in applying the Dakin v. Lee principle to the facts of the present case. I can see no reason why that principle should be approached with wariness and applied with caution. In 
certain cases it is right that the rigid rule for which the Defendant contends should be applied; for example, if a man tells a contractor to build a $10 \mathrm{ft}$. wall for him in his garden and agrees to pay $£ X$ for it, it would not be right that he should be held liable for any part of the contract price if the contractor builds the wall to $2 \mathrm{ft}$. and then renounces further performance of the contract, or builds the wall of a totally different material from that which was ordered or builds it at the wrong end of the garden. The work contracted for has cot been done and the corresponding obligation to pay consequently never arises. But when a, man fully performs his contract in the sense that he supplies all that he agreed to supply but what he supplies is subject to defects of so minor a character that he can be said to have substantially performed his promise, it is in my judgment far more equitable to apply the Dakin v. Lee principle than to deprive him wholly of his contractual rights and relegate him to such remedy (if any) as he may have on a quantum meruit; nor, in my judgment, are we compelled to a contrary view (having regard to the nature and terms of the agreement and the Official Referee's finding) by any of the cases in the books.

The position is, I think, in some respects analogous to a case where a man agrees to sell land and, before completion, finds that he is unable to make title to a small part of it which is of no great significance in relation to the whole. In such a case the vendor can substantially perform what he has agreed to do but cannot perform it wholly, and the Court of Chancery has never hesitated to grant specific performance at his instance against the purchaser subject to a proper and reasonable deduction being made in the purchase price; it would not, however, make such an order if it resulted in the purchaser getting something substantially less than or different from what he had bargained for. The general principle is clearly stated in Fry on Specific Performance (6th Edition, 1213) as follows:

"The description by which a. thing is contracted to be sold is a matter for which the vendor is prima facie responsible. Inasmuch, however, as Equity looks to the substance rather than to the mere letter of a contract, if the vendor shows that he can substantially do what he contracted to do he is entitled to enforce specific performance, although he may be unable to do it modo et forma according to the letter of the contract; the 
difference between what he contracted to do and what he can actually do becoming the subject of compensation."

I am accordingly of the opinion, as already indicated, that the learned Official Referee fell into no error of law and that this appeal fails. If, however, I had come to a different conclusion on the point which I have been considering I should nevertheless be inclined to the view (for the reasons stated by Lord Justice Denning in his judgment) that the appeal must fail on the ground of the Defendant's waiver.

(Appeal dismissed with costs: leave to appeal refused) 


\section{Cutter v. Powell}

KBD 9 JUN 1795

December 6, 2018 admin, Contract, Employment,

References: [1795] EWHC KB J13, [1795] EngR 4125, (1795) 6 TR 320, (1795) 101 ER 573.

\section{Links: Bailii, $\underline{\text { Commonlii }}$}

Ratio: The plaintiff's estate sought payment from the employer who had agreed to pay the deceased thirty pounds for an entire voyage. The plaintiff died part way through the voyage. The estate argued for payment on a quantum meruit.

Held: The court found there was no standard custom and practice. The contract was for an entire service. It was a condition precedent for payment that that service be completed. It had not been, and no payment was due. Ashurst J said: 'This is a written contract, and it speaks for itself. And as it is entire, and as the defendant's promise depends on a condition precedent to be performed by the other party, the condition must be performed before the other party is entitled to receive any thing under it. It has been argued however that the plaintiff may now recover on a quantum meruit: but she has no right to desert the agreement; for wherever there is an express contract the parties must be guided by it; and one party cannot relinquish or abide by it as it may suit his advantage.'

Jurisdiction: England and Wales

Last Update: 06 December 2018, Ref: 248375

All Answers ltd, 'Cutter v Powell - 1795' (Lawteacher.net, December 2018) $<$ https://www.lawteacher.net/cases/cutter-v-powell.php?vref=1> accessed 20 December 2018. 


\section{Dakin v. Lee}

Também conhecido como H. Dakin \& Co. Ltd. v. Lee.

\section{Dakin v Lee [1916] 1 KB 566}

The defendants promised to build a house according to specification and failed to carry out exactly all the specifications, for example, concrete not four feet deep as specified, wrong joining of certain rolled steel joists and concrete not properly mixed. The Court of Appeal held that the builders were entitled to recover the contract price, less so much as ought to be allowed in respect of the items found to be defective.

All Answers ltd, 'Discharge Cases | Discharge of Contract' (Lawteacher.net, December 2018) <https://www.lawteacher.net/cases/discharge-cases.php?vref=1> accessed 20 December 2018. 


\section{Allegheny College vs. National Chautauqua Count bank of Jamestown}

Citation. 22 Ill.246 N.Y. 369, 159 N.E. 173 (1927)

Brief Fact Summary. The Defendant, National Chautauqua County Bank of Jamestown (Defendant), promised to pay Plaintiff, Allegheny College (Plaintiff), $\$ 5,000$ for a scholarship fund in Defendant's name. Plaintiff accepted part payment and held the money for the fund. Defendant refused to pay the remaining balance of the $\$ 5,000$.

Synopsis of Rule of Law. An assumption of duty to promise whatever was necessary to carry out the conditions of her gift is valid consideration.

Facts. Plaintiff sent a letter of appeal as part of its fundraising drive to Johnston who at the time of the case was deceased. In response, Johnson sent a letter promising $\$ 5,000$ due 30 days after her death. The letter ordered her Executor to pay the sum out of the estate added to Plaintiff's endowment in accordance with instructions found on the reverse of the letter. The reverse said "In loving memory this gift shall be known as the Mary Yates Johnston Memorial Fund, the proceeds from which shall be used to educate students preparing for the Ministry, either in the U.S. or in the Foreign Field." Made only on the condition that provisions of her will are first met. \$1,000 was paid two years after the date of letter and while Johnston was still alive. Plaintiff put this money aside to be held as a scholarship in Johnson's name. Later Johnston sent notice of her revocation. Thirty days after Johnston's death Plaintiff brought the suit against the executors.

Issue. Is the promise made with consideration and thus enforceable? 
246 N. Y. 369

ALLEGHENY COLLEGE, Appellant, v. THE NATIONAL CHAUTAUQUA COUNTY BANK OF JAMESTOWN, as Executor of MARY Y. JOHNSTON, Deceased, Respondent.

Supreme Court of New York, Appellate Division, Fourth Department

$\underline{2}$

[...]

$\underline{3456}$

CARDOZO, Ch. J. The plaintiff, Allegheny College, is an institution of liberal learning at Meadville, Pennsylvania. In June 1921, a "drive" was in progress to secure for it an additional endowment of $\$ 1,250,000$. An appeal to contribute to this fund was made to Mary Yates Johnston of Jamestown, New York. In response thereto, she signed and delivered on June 15, 1921, the following writing:

7

"Estate Pledge,

"Allegheny College Second Century Endowment

"JAMESTOWN, N. Y., June 15, 1921."

"In consideration of my interest in Christian Education, and in consideration of others subscribing, I hereby subscribe and will pay to the order of the Treasurer of Allegheny College, Meadville, Pennsylvania, the sum of Five Thousand Dollars; \$5,000.

"This obligation shall become due thirty days after my death, and I hereby instruct my Executor, or Administrator, to pay the same out of my estate. This pledge shall bear interest at the rate of . . per cent per annum, payable annually, from . . . till paid. The proceeds of this obligation shall be added to the Endowment of said Institution, or expended in accordance with instructions on reverse side of this pledge."

"Name MARY YATES JOHNSTON,

"Address 306 East 6th Street,

"Jamestown, N. Y.

"DAYTON E. MCCLAIN Witness

"T. R. COURTIS Witness 
to authentic signature."

[372] On the reverse side of the writing is the following endorsement:

$\underline{9}$

"In loving memory this gift shall be known as the Mary Yates Johnston Memorial Fund, the proceeds from which shall be used to educate students preparing for the Ministry, either in the United States or in the Foreign Field.

"This pledge shall be valid only on the condition that the provisions of my Will, now extant, shall be first met.

\section{"MARY YATES JOHNSTON."}

$\underline{10}$

The subscription was not payable by its terms until thirty days after the death of the promisor. The sum of $\$ 1,000$ was paid, however, upon account in December, 1923, while the promisor was alive. The college set the money aside to be held as a scholarship fund for the benefit of students preparing for the ministry. Later, in July, 1924, the promisor gave notice to the college that she repudiated the promise. Upon the expiration of thirty days following her death, this action was brought against the executor of her will to recover the unpaid balance.

$\underline{11}$

The law of charitable subscriptions has been a prolific source of controversy in this State and elsewhere. We have held that a promise of that order is unenforcible like any other if made without consideration (Hamilton College v. Stewart, 1 N. Y. 581; Presb. Church v. Cooper, 112 N. Y. 517; 23rd St. Bap. Church v. Cornell, 117 N. Y. 601). On the other hand, though professing to apply to such subscriptions the general law of contract, we have found consideration present where the general law of contract, at least as then declared, would have said that it was absent [...]

\section{$\underline{12}$}

A classic form of statement identifies consideration with detriment to the promisee sustained by virtue of the promise (Hamer v. Sidway, 124 N. Y. 538; Anson, Contracts [Corbin's ed.], p. 116; 8 Holdsworth, History of English Law, 10). So compendious a formula is little more than a half truth. There is need of many a supplementary gloss before the outline can be so filled in as to depict the classic doctrine. "The promise and 
the consideration must purport to be the motive each for the other, in whole or at least in part. It is not enough that the promise induces the detriment or that the detriment induces the promise if the other half is wanting" (Wise. \& Mich. Ry. Co. v. Powers, 191 U. S. 379, 386; McGovern v. City of N. Y., 234 N. Y. 377, 389; Walton Water Co. v. Village of Walton, 238 N. Y. 46, 51; 1 Williston, Contracts, §139; Langdell, Summary of the Law of Contracts, pp. 82-88). If A promises B to make him a gift, consideration may be lacking, though B has renounced other opportunities for betterment in the faith that the promise will be kept.

$\underline{13}$

The half truths of one generation tend at times to perpetuate themselves in the law as the whole truths of another, when constant repetition brings it about that qualifications, taken once for granted, are disregarded or forgotten. The doctrine of consideration has not escaped the common lot. As far back as 1881, Judge HOLMES in his lectures on the Common Law (p. 292), separated the detriment which is merely a consequence of the promise from the detriment which is in truth the motive or inducement, and yet added that the courts "have gone far in obliterating this distinction."The tendency toward effacement has not lessened with the years. On the contrary, there has grown up of recent days a doctrine that a substitute for consideration or an exception to its ordinary requirements can be found in [374] what is styled " a promissory estoppel " (Williston, Contracts, $\S \S 139,116)$. Whether the exception has made its way in this State to such an extent as to permit us to say that the general law of consideration has been modified accordingly, we do not now attempt to say. Cases such as Siegel v. Spear \& Co. (234 N. Y. 479) and DeCiccov. Schweizer (221 N. Y. 431) may be signposts on the road. Certain, at least, it is that we have adopted the doctrine of promissory estoppel as the equivalent of consideration in connection with our law of charitable subscriptions. So long as those decisions stand, the question is not merely whether the enforcement of a charitable subscription can be squared with the doctrine of consideration in all its ancient rigor. The question may also be whether it can be squared with the doctrine of consideration as qualified by the doctrine of promissory estoppel.

$\underline{14}$

We have said that the cases in this State have recognized this exception, if exception it is thought to be. Thus, in Barnes v. Perine (12 N. Y. 18) the subscription was made without request, express or implied, that the church do anything on the faith of it. Later, 
the church did incur expense to the knowledge of the promisor, and in the reasonable belief that the promise would be kept. We held the promise binding, though consideration there was none except upon the theory of a promissory estoppel. In Presbyterian Society v. Beach (74 X. Y. 72) a situation substantially the same became the basis for a like ruling. So in Roberts v. Cobb (103 N. Y. 600) and Keuka College v. Ray (167 N. Y. 96) the moulds of consideration as fixed by the old doctrine were subjected to a like expansion. Very likely, conceptions of public policy have shaped, more or less subconsciously, the rulings thus made. Judges have been affected by the thought that "defences of that character" are "breaches of faith toward the public, and especially toward those engaged in the same enterprise, and an unwarrantable disappointment of the reasonable expectations of those interested" (W. F. [375] ALLEN, J., in Barnes v. Perine, supra, page 24; and cf. Eastern States League v. Vail, 97 Vt. 495, 505, and cases there cited). The result speaks for itself irrespective of the motive. Decisions which have stood so long, and which are supported by so many considerations of public policy and reason, will not be overruled to save the symmetry of a concept which itself came into our law, not so much from any reasoned conviction of its justice, as from historical accidents of practice and procedure (8 Holdsworth, History of English Law, 7 et seq.). The concept survives as one of the distinctive features of our legal system. We have no thought to suggest that it is obsolete or on the way to be abandoned. As in the case of other concepts, however, the pressure of exceptions has led to irregularities of form.

\section{$\underline{15}$}

It is in this background of precedent that we are to view the problem now before us. The background helps to an understanding of the implications inherent in subscription and acceptance. This is so though we may find in the end that without recourse to the innovation of promissory estoppel the transaction can be fitted within the mould of consideration as established by tradition. The promisor wished to have a memorial to perpetuate her name. She imposed a condition that the "gift" should "be known as the Mary Yates Johnston Memorial Fund." The moment that the college accepted \$1,000 as a payment on account, there was an assumption of a duty to do whatever acts were customary or reasonably necessary to maintain the memorial fairly and justly in the spirit of its creation. The college could not accept the money, and hold itself free thereafter from personal responsibility to give effect to the condition (Dinan v. Coneys, 
143 N. Y. 544, 547; Brown v. Knapp, 79 N. Y. 136; Gridley v. Gridley, 24 N. Y. 130; Grossman v. Schenker, 206 N. Y. 466, 469; 1 Williston, Contracts, §§90, 370). More is involved in the receipt of such a fund than a mere acceptance of money to be held to a corporate use [376] (cf. Martin v. Meles, 179 Mass. 114, citing Johnson v. Otterbein University, 41 Ohio St. 527, 531, and Presb. Church v. Cooper, 112 N. Y. 517). The purpose of the founder would be unfairly thwarted or at least inadequately served if the college failed to communicate to the world, or in any event to applicants for the scholarship, the title of the memorial. By implication it undertook, when it accepted a portion of the "gift," that in its circulars of information and in other customary ways, when making announcement of this scholarship, it would couple with the announcement the name of the donor. The donor was not at liberty to gain the benefit of such an undertaking upon the payment of a part and dis- appoint the expectation that there would be payment of the residue. If the college had stated after receiving \$1,000 upon account of the subscription that it would apply the money to the prescribed use, but that in its circulars of information and when responding to prospective applicants it would deal with the fund as an anonymous donation, there is little doubt that the subscriber would have been at liberty to treat this statement as the repudiation of a duty impliedly assumed, a repudiation justifying a refusal to make payments in the future. Obligation in such circumstances is correlative and mutual. A case much in point is N. J. Hospital v. Wright (95 N. J. L. 402, 464), where a subscription for the maintenance of a bed in a hospital was held to be enforcible by virtue of an implied promise by the hospital that the bed should be maintained in the name of the subscriber (cf. Bd. of Foreign Missions v. Smith, 209 Tenn. St. 361). A parallel situation might arise upon the endowment of a chair or a fellowship in a university by the aid of annual payments with the condition that it should commemorate the name of the founder or that of a member of his family. The university would fail to live up to the fair meaning of its promise if it were to publish in its circulars of information and elsewhere the [377] existence of a chair or a fellowship in the prescribed subject, and omit the benefactor's name. A duty to act in ways beneficial to the promisor and beyond the application of the fund to the mere uses of the trust would be cast upon the promisee by the acceptance of the money. We do not need to measure the extent either of benefit to the promisor or of detriment to the promisee implicit in this duty. "If a person chooses to make an extravagant promise for an inadequate consideration it is his own affair" (8 Holdsworth, History of English Law, 
p. 17). It was long ago said that "when a thing is to be done by the plaintiff, be it never so small, this is a sufficient consideration to ground an action" (Sturlyn v. Albany, 1587, Cro. Eliz. 67, quoted by Holdsworth, supra; cf. Walton Water Co. v. Village of Walton, $238 \mathrm{~N}$. Y. 46, 51). The longing for posthumous remembrance is an emotion not so weak as to justify us in saying that its gratification is a negligible good.

$\underline{16}$

We think the duty assumed by the plaintiff to perpetuate the name of the founder of the memorial is sufficient in itself to give validity to the subscription within the rules that define consideration for a promise of that order. When the promisee subjected itself to such a duty at the implied request of the promisor, the result was the creation of a bilateral agreement (Williston, Contracts, $\S \S 60$-a, 68, 90, 370; Brown v. Knapp, supra; Grossman v. Schenker, supra; Williams College v. Danforth, 12 Pick. 541, 544; Ladies Collegiate Inst. v. French, 16 Gray, 196, 200). There was a promise on the one side and on the other a return promise, made, it is true, by implication, but expressing an obligation that had been exacted as a condition of the payment. A bilateral agreement may exist though one of the mutual promises be a promise "implied in fact," an inference from conduct as opposed to an inference from words (Williston, Contracts, $\S \S 90,22-a$; Pettibone v. Moore, 75 Hun, 461, 464). We think the fair inference to be drawn from the [378] acceptance of a payment on account of the subscription is a promise by the college to do what may be necessary on its part to make the scholarship effective. The plan conceived by the subscriber will be mutilated and distorted unless the sum to be accepted is adequate to the end in view. Moreover, the time to affix her name to the memorial will not arrive until the entire fund has been collected. The college may thus thwart the purpose of the payment on account if at liberty to reject a tender of the residue. It is no answer to say that a duty would then arise to make restitution of the money. If such a duty may be imposed, the only reason for its existence must be that there is then a failure of "consideration." To say that there is a failure of consideration is to concede that a consideration has been promised since otherwise it could not fail. No doubt there are times and situations in which limitations laid upon a promisee in connection with the use of what is paid by a subscriber lack the quality of a consideration, and are to be classed merely as conditions (Williston, Contracts, §112; Page, Contracts, §523). 
"It is often difficult to determine whether words of condition in a promise indicate a request for consideration or state a mere condition in a gratuitous promise. An aid, though not a conclusive test in determining which construction of the promise is more reasonable is an inquiry whether the happening of the condition will be a benefit to the promisor. If so, it is a fair inference that the happening was requested as a consideration"

$\underline{18}$

(Williston, supra, §112). Such must be the meaning of this transaction unless we are prepared to hold that the college may keep the payment on account, and thereafter nullify the scholarship which is to preserve the memory of the subscriber. The fair implication to be gathered from the whole transaction is assent to the condition and the assumption of a duty to "go forward with performance (DeWolf Co. v. Harvey, 161 Wis. 535; Pullman Co. v. Meyer, 195 Ala. 397, 401; Braniff v. Baier, [379] 101 Kan. 117; cf. Corbin, Offer \& Acceptance, 26 Yale L. J. 169, 177, 193; McGovney, Irrevocable Offers, 27 Harv. L. R. 644; Sir Frederick Pollock, 28 L. Q. R. 100, 101). The subscriber does not say: I hand you $\$ 1,000$, and you may make up your mind later, after my death, whether you will undertake to commemorate my name. What she says in effect is this: I hand you $\$ 1,000$, and if you are unwilling to commemorate me, the time to speak is now. The conclusion thus reached makes it needless to consider whether, aside from the feature of a memorial, a promissory estoppel may result from the assumption of a duty to apply the fund, so far as already paid, to special purposes not mandatory under the provisions of the college charter (the support and education of students preparing for the ministry), an assumption induced by the belief that other payments sufficient in amount to make the scholarship effective would be added to the fund thereafter upon the death of the subscriber (Ladies Collegiate Inst. v. French, 16 Gray, 196; Barnes v. Perine, 12 N. Y. 18, and cases there cited).

$\underline{19}$

The judgment of the Appellate Division and that of the Trial Term should be reversed, and judgment ordered for the plaintiff as prayed for in the complaint, with costs in all courts.

$\underline{20}$

KELLOGG, J. (dissenting). The Chief Judge finds in the expression "In loving memory this gift shall be known as the Mary Yates Johnston Memorial Fund" an offer on the 
part of Mary Yates Johnston to contract with Allegheny College. The expression makes no such appeal to me. Allegheny College was not requested to perform any act through which the sum offered might bear the title by which the offeror states that it shall be known. The sum offered was termed a "gift" by the offeror. Consequently, I can see no reason why we should strain ourselves to make it, not a gift, but a trade. [380] Moreover, since the donor specified that the gift was made "In consideration of my interest in Christian education, and in consideration of others subscribing," considerations not adequate in law, I can see no excuse for asserting that it was otherwise made in consideration of an act or promise on the part of the donee, constituting a sufficient quid quo pro to convert the gift into a contract obligation. To me the words used merely expressed an expectation or wish on the part of the donor and failed to exact the return of an adequate consideration. But if an offer indeed was present, then clearly it was an offer to enter into a unilateral contract. The offeror was to be bound provided the offeree performed such acts as might be necessary to make the gift offered become known under the proposed name. This is evidently the thought of the Chief Judge, for he says: "She imposed a condition that the 'gift' should be known as the Mary Yates Johnston Memorial Fund." In other words, she proposed to exchange her offer of a donation in return for acts to be performed. Even so there was never any acceptance of the offer and, therefore, no contract, for the acts requested have never been performed. The gift has never been made known as demanded. Indeed, the requested acts, under the very terms of the assumed offer, could never have been performed at a time to convert the offer into a promise. This is so for the reason that the donation was not to take effect until after the death of the donor, and by her death her offer was withdrawn. (Williston on Contracts, sec. 62.) Clearly, although a promise of the college to make the gift known, as requested, may be implied, that promise was not the acceptance of an offer which gave rise to a contract. The donor stipulated for acts, not promises.

21

"In order to make a bargain it is necessary that the acceptor shall give in return for the offer or the promise exactly the consideration which the offeror requests. If an act is requested, that very act and no other must be [381] given. If a promise is requested, that promise must be made absolutely and unqualifiedly." 
(Williston on Contracts, sec. 73.)

$\underline{23}$

"It does not follow that an offer becomes a promise because it is accepted; it may be, and frequently is, conditional, and then it does not become a promise until the conditions are satisfied; and in case of offers for a consideration, the performance of the consideration is always deemed a condition."

$\underline{24}$

(Langdell, Summary of the Law of Contracts, sec. 4.) It seems clear to me that there was here no offer, no acceptance of an offer, and no contract. Neither do I agree with the Chief Judge that this court "found consideration present where the general law of contract, at least as then declared, would have said that it was absent" in the cases of Barnes v. Ferine (12 N. Y. 18), Presbyterian Society v. Beach (74 N. Y. 72) and Keuka College v. Ray (167 N. Y. 96). In the Keuka College case an offer to contract, in consideration of the performance of certain acts by the offeree, was converted into a promise by the actual performance of those acts. This form of contract has been known to the law from time immemorial (Langdell, sec. 46) and for at least a century longer than the other type, a bilateral contract. (Williston, sec. 13.) It may be that the basis of the decisions in Barnes v. Perine and Presbyterian, Society v. Beach (supra) was the same as in the Keuka College case. (See Presbyterian Church of Albany v. Cooper, 112 N. Y. 517.) However, even if the basis of the decisions be a so-called " promissory estoppel," nevertheless they initiated no new doctrine. A so-called " promissory estoppel," although not so termed, was held sufficient by Lord MANSFIELD and his fellow judges as far back as the year 1765. (Pillans v. Van Mierop, 3 Burr. 1663.) Such a doctrine may be an anomaly; it is not a novelty. Therefore, I can see no ground for the suggestion that the ancient rule which makes consideration necessary to the formation of every contract is in danger of effacement through any decisions [382] of this court. To me that is a cause for gratulation rather than regret. However, the discussion may be beside the mark, for I do not understand that the holding about to be made in this case is other than a holding that consideration Was given to convert the offer into a promise. With that result I cannot agree and, accordingly, must dissent.

$\underline{25}$

POUND, CRANE, LEHMAN and O'BRIEN, JJ., concur with CARDOZO, Ch. J.; KELLOGG, J. dissents in opinion, in which ANDREWS, J., concurs. 
$\underline{26}$

Judgment accordingly.

Available at Casebriefs.com Web site, owned and operated by Casebriefs LLC. 


\section{$\underline{\text { Rann v. Hughues }}$}

\section{Description}

This section is from the book "Business Law - Case Method", by William Kixmiller, William H. Spencer. See also: Business Law: Text and Cases.

\section{(2) Simple Contracts}

\section{Story Case}

Harry Branscomb, who owned a number of fine horses, promised to give one to his brother Frank after a few weeks. Frank insisted that the promise should be put in writing, because he feared that his brother might change his mind in the meantime and he thought that by having the promise made in writing, he could enforce it, in case his brother should change his mind.

Before the time came when, according to the writing, the horse was to be delivered to Frank, Harry sold all of his horses. This action angered Frank and he decided to sue his brother for damages. In defense Harry contended that, because there was no consideration, his promise was not legally binding upon him. On the other hand it was contended by Frank that it was not material that there was no consideration, since the promise was made in writing.

Under these facts, do you think that Harry Brans-comb is liable for damages?

\section{Ruling Court Case. Hughes Vs. Rann, Volume 7 Term Reports, Note, Page 350}

During the respective life-times of Mary Hughes and J. Hughes a certain dispute arose between them. They agreed to submit the matter to arbitration. The arbitrators, having made an investigation into the controversy, decided that Mary Hughes should pay J. Hughes the sum of 983 pounds. 
Thereafter she died and Rann, the present defendant, was appointed her executor. Although sufficiently able to have done so in her life time, Mary Hughes never paid the 983 pounds which the arbitrators found that she owed to J. Hughes. Rann, her executor after her death, agreed by a promise in writing to pay the sum in question. For his promise, however, there was no consideration.

J. Hughes brought this action upon the promise made by Rann, executor of the estate of Mary Hughes, deceased.

In defense, Rann contended that he was not liable upon the promise because it was not supported by a consideration. In reply to this the plaintiff contended that it was immaterial whether or not there was a consideration for this promise, because the promise was made in writing.

\section{Decision}

The defendant, Rann, cannot be held liable upon this promise, even though in writing, because it is not supported by a consideration.

Lord Chief Baron Skynner said in part: "All contracts are divided into agreements by specialty and agreements by parol - simple contracts. Nor is there any such third class as some of the counsel have endeavored to maintain, as contracts in writing. If they be merely written and not sealed, they are parol simple contracts - and a consideration must be proved".

Accordingly, judgment was given for the defendant in this action.

\section{Ruling Law. Story Case Answer}

As was stated in the foregoing section, all contracts are either simple or sealed contracts. A sealed instrument becomes a binding obligation by virtue of its form and execution, and a consideration therefor was unnecessary. On the other hand, as is illustrated more 
fully later, a simple contract must be supported by a consideration, before it becomes a binding obligation.

Quite frequently we speak of contracts which are written and contracts which are oral. But a contract, whether oral or written, is termed a simple contract and must always contain a consideration. In the Story Case, Frank was mistaken when he thought that a written contract would be binding, when unsupported by a consideration. By having it reduced to writing, he could no more easily have it enforced than if it had been a mere oral promise.

Continue to:

prev: 2. Contract Classified. A. Contract May Be Under Seal Or May Be Simple. (1) $\underline{\text { Sealed Contracts }}$

$\underline{\text { Table of Contents }}$

next: B. Contracts May Be Express Or Implied. (1) Express Contracts

Available and Copyrighted by http://chestofbooks.com/ and (C) 2007-2018 StasoSphere.com. 


\section{Mondel v Steel}

\section{EXCH. OF PLEAS.}

\section{Original Citation: (1841) 8 M \& W 858}

\section{English Reports Citation: 151 E.R. 1288}

S. C. 6 Dowl. (N. S.) 1; 10 L. J. Ex. 426. Referred to, Heyworth v. Hutchinson, 1867, L. R. 2 Q. B. 451; Davis v. Hedges, 1871, L. R. 6 Q. B. 689; Towerson v. Aspatria, etc., Society, 1873, 27 L. T. 276.

[858] Mondel v. Steel. Exch. of Pleas. 1841.- Special assumpsit on a contract to build a ship according to a specification, assigning a breach in not building the ship with scantling, fastening, and planking, according to the specification, and alleging special damage. Plea, that the defendant had sued the plaintiff' for the balance of the agreed price of the ship, after payment of 3500, and also for a sum of 150 for extra work, in the form of an action for work and labour, and for goods sold and delivered ; that issue was joined, and, on the trial of the cause, the now plaintiff' gave evidence in his defence of the same breach of contract alleged in the declaration, and insisted, if the amount of compensation to which he was entitled exceeded or equalled the balance and value of the extra work, that he the now plaintiff was entitled to a verdict; if less, then he was entitled to a deduction, upon the amount of both, to the extent of such amount of compensation : that the Judge who tried the cause so directed the jury, and the jury found that the now defendant had committed a breach of the contract, and that the now plaintiff was entitled to some compensation, which they deducted from the price of the ship and the value of the extra work : that the now defendant had judgment for the amount, after such deduction had been made, since the commencement of this suit:Held, that the plea was bad on general demurrer.- Held, also, that all that the plaintiff could by law be allowed in diminution of damages on the former trial, was a deduction from the agreed price, according : to the difference between the ship as she was at the 
time of delivery, and what she ought to have been according to the contract: but that any claim for damages on account of the subsequent necessity for repairs could not be allowed in the former action, and might be recovered in this.-In all actions for goods sold and delivered with a warranty, or for work and labour, as well as in actions for ; goods agreed to be supplied according to a contract, it is competent for the defendant to shew how much leas the subject-matter of the action was worth by reason of the breach of the contract: and to the extent that he obtains, or is capable of obtaining, an abatement of price on that account, he must be considered as having received satisfaction for the breach of contract; and he is precluded from recovering in another action to that extent, but no more.

Special assumpsit on a contract to build a ship for the plaintiff, at a certain rate per1 ton, and according to a certain specification (setting it out); and the breach assigned was, for not building the ship with scantling, fastening, and planking, according to the specification; by reason whereof the ship, in a certain voyage, was so much strained that it became necessary to refasten and repair her; and thereby thef plaintiff lost the use of her during the time she was undergoing such repairs.

'Plea, that the plaintiff ought not further to maintain his said action in respect of the-said alleged breach of contract in the declaration mentioned, because the defendant says that he the defendant, heretofore, to wit, on \&c., before the Barons of her Majesty's Court of Exchequer at Westminster, in the county of Middlesex, irapleaded the plaintiff in an action on promises, and by the said action sought to recover from the plaintiff, over and above a sum of $21.4 \mathrm{~s}$. 9Jd. hereinafter mentioned, the sum of $861.6 \mathrm{~s} .4 \mathrm{~d}$., being the balance of the price of the said ship in the said declaration mentioned, calculated according to the provisions and terms of the said memorandum of agreement [859] therein also mentioned, and which remained unpaid to him the now defendant, after the payment by the now plaintiff to him of the sum of $31.5 \mathrm{~s}$., in the said declaration also mentioned, and after credit being given to the now plaintiff for two other sums hereinafter mentioned; and also to recover from the now plaintiff the further suni of 1341. 3s. 2d., being the value of certain work, labour, and materials done and provided for the now plaintiff by the now defendant in and about the said ship, and 


\section{M.\&W.880. MONDEL V. STEEL 1289}

which were extra of and in addition to the work, labour, and materials mentioned and included in the said memorandum of agreement. [The plea then set out the whole of the pleadings in that action, which was inrlebitatus assumpsit in 4000, for work and materials, goods sold and delivered, and on an account stated:-pleas, 1st, except as to '21. 4s. 9jd., parcel \&c., non assumpsit ; 2nclly, as to the 21. 4s. 9id., payment into Court of that sum, which the now defendant accepted ; 3rdly, except as to 21. 4s. Bjd., payment, which was denied by the replication ; 4thly, except as to $21.4 \mathrm{~s}$. 9d., a sot-off for work and materials, goods sold and delivered, money paid, and on an account stated. The plea then proceeded as follows :]- And the defendant further saith, that all the said issues were duly joined between him the now defendant, and the now plaintiff, and afterwards, to wit, at the General Sessions of Assize holden at Liverpool, in and for the southern division of the county palatine of Lancaster, on \&c., before Sir William Henry Maule, Knight, one of the Justices of our Lady the Queen of her Court of Common Pleas at Westminster, and Sir Robert Mounsey Rolfe, Knight, one of the Harons of our said Lady the Queen of her Court of Exchequer at Westminster, Justices of our said Lady the Queen of her Court of Common Pleas of the said county palatine, the said issues so as aforesaid joined came on in due and regular form of law, to be tiled before the said Sir Robert Mounsey Rolfe, and the same [860] were then tried in due course of law, by a jury of the county duly summoned, chosen, and sworn in that behalf, between the now defendant and the now plaintiff. And the defendant further says, that at the said trial he, the now defendant, duly proved and gave in evidence the said memorandum of agreement in the said declaration mentioned, and further proved the delivery to and acceptance by the now plaintiff of the ship thereby contracted to be built, and that the pi-ice thereof, calculated according to the provisions and terms of the said memorandum of agreement in that behalf, amounted to the sum of $360 \mathrm{cSl} .3 \mathrm{~s} .10 \mathrm{~d}$., whereof the now plaintiff had paid him, the now defendant, the said sum of 3500 in the said declaration mentioned, and was also entitled to credit for two other sums, namely, 181. 7 s. $6 \mathrm{~d}$. and $31.10 \mathrm{~s}$., leaving the said sum of $861.6 \mathrm{~s}$. $4 \mathrm{~d}$., the balance, unpaid to the now defendant; and ha the defendant further proved and gave evidence that he, the now defendant, had done and provided for the now plaintiff, and at his request, for the said ship, work, labour, and materials, to the value of 1341. '3s. 2d., which was extra of and in addition to the work, labour, and materials in the said memorandum of agreement 
mentioned. And the now defendant further says, that the now plaintiff, at the said trial, and in defence of the said causes of action of him the now defendant, and in answer thereto, averred and gave evidence of the very same and identical breach of contract alleged by the now plaintiff to have been committed by the now defendant hi the gaid declaration in this suit, that is to say, that the now defendant did not build the said ship of the very best materials, in conformity with the said specification in the said declaration mentioned, and did not build the same with the whole of the scantling, fastening, and planking inside and outside, such as is mentioned in Lloyd's Survey Book for a twelve years' ship, but omitted and neglected so to do. And the defendant further says, that the now plaintiff, at the said trial, produced witnesses and [361] gave evidence in support of his said alleged defence, and in answer to the said Causes of action of him the now defendant; and then insisted at the said trial, that if the said jury were of opinion and found that the now defendant had committed the said breach of contract, or any part thereof, and that the amount of compensation or of damages to which he the now plaintiff was entitled by reason thereof, exceeded or equalled the amount of the said balance, and the value of the said extra and additional work, labour, and materials as aforesaid, that he, the now plaintiff, was entitled to have the verdict found for him. And further, that if the said jury were of opinion and found that he the said plaintiff was entitled to any compensation or damages in tespect of the said alleged breach of contract, or any part thereof, although the same tnight be less in amount than the amount of the said balance, and the said value of the said extra and additional work, labour, and materials, that he the now plaintiff was entitled to have the same deducted from the said last-mentioned amount; and the said now plaintiff then prayed the said Baron to state to and inform the said jury, that he the now plaintiff was so entitled. And the defendant further saith, that in pursuance of such prayer of the now plaintiff, and in accordance therewith, the said Baron did then, in summing up the evidence at the said trial, state to and direct the said jury, that if they found and were of opinion that the now defendant had corn-Ex. Drv. vii.-41*

12BO MONDEL V. STEEL 8 M. \& W. 882.

minted the s;iid [sic] alleged breach of contract, or any part thereof, that they should decide and ascertain what was the amount of compensation or damages to which the 
now plaintiff was entitled by reason thereof ; and that if the said compensation or damages equalled or exceeded the amount of the said balance, and the value of the said extra and additional work and labour and materials, that they should find their verdict for the plaintiff in this action ; and that if the amount of compensation or damages to which [862] they found the plaintiff in this action was entitled, was less than the amount of the said balance and the value of the said extra and additional work and labour and materials, that they should deduct such compensation or damages from the said amount, and find their verdict for the defendant in this action for the difference only. And the defendant further says, that the said jury, in pursuance of suah direction, did then find that the defendant in this action had committed a breach of the said contract in the declaration in this action mentioned, and that the plaintiff in this action was entitled to compensation and damages in respect thereof; and then found their verdict for the now defendant, for the difference only between the said compensation and damages which they so found the plaintiff in this action was entitled to by reason of the said breach of contract, and the amount of the said balance, and tha value of the said extra and additional work and labour and materials as aforesaid, that is to say, for the sum of 120 only, which was considerably less than the amount of the said balance as aforesaid, and the value of the said extra and additional work and labour and materials. And the defendant further says, that the said jury then found all the said issues so as aforesaid joined for him the defendant, and assessed his; damages on occasion of the premises in the said action, besides his costs and charges by him in his said suit, to the said sum of 120 as aforesaid, and those costs and charges to 40s.; and such proceedings were afterwards had in her Majesty's said Court of Exchequer at Westminster, that afterwards, and after the commencement of this suit, to -wit, on \&c. aforesaid, it was considered by the said Court that the now defendant should recover against the now plaintiff his said damages, costs, and charges by the jury aforesaid in form aforesaid assessed, and also 262 for his costs and charges by the said Court adjudged of increase to the now defendant, with his assent, which said [863] damages, costs and charges in the whole amounted to 384, and the now plaintiff in mercy, \&c.; as by the record and proceedings thereof still remaining in the said Court of our Lady the Queen, before the Barons of her Exchequer at Westminster, more fully and at large appears, which said judgment still remains in full force and effect, not in the least reversed or made void. And the defendant in fact saith, that the said alleged breach of contract by the now 
defendant, or by the plaintiff in the declaration in this suit alleged, is the very same identical breach of contract so alleged and proved by the now plaintiff at the said trial, and relied upon by ;him as aforesaid, and for and in respect of which he obtained such compensation and damages as aforesaid. Verification and prayer of judgment.

Special demurrer, and joinder in demurrer.

Cleasby in support of the demurrer. The plea is bad in substance. The facts stated in it afford no answer to the present action, which is brought to recover the special damage resulting from the breach of contract. He was then stopped by the Court, who called on Martin to support the plea. The plea shews that the defendant has already received a compensation for the breach of contract, and that is an answer to the action. If a person elects to receive compensation for a breach of warranty or contract, it ia a satisfaction. An impression formerly prevailed, that when a party contracted to pay a stipulated price for work and labour, the party performing it was entitled to recover the stipulated price, and that the only remedy for a breach of the contract was by a cross action. But in Hasten v. Butter (7 East, 479) a different opinion was entertained, and it was there held, that where the plaintiff declared upon a quantum meruit for work and [864] labour and materials, it was competent to the defendant, even without notice to the plaintiff, to prove that the work was not worth so much as the plaintiff clajmed ; and if it appeared that the plaintiff had been paid on account as much as the work was worth, he could not recover. In Pmtlton v. Lattimore (9 B. \& C. 259; 4 Man. \& By.ò 208), where, by a contract for the sale of cinque-foin seed, the vendor warranted it to be good new-growing seed, and soon after the sale the buyer was told that it did not correspond with the warranty, and he afterwards sowed part and sold the residue; it was held, that in an action to recover the price, it was competent to

\section{M. \&W. 86S MONDEL V. STEEL 1291}

the buyer to shew that the seed did not correspond with the warranty. Bayley, J., there says, "From the nature of the article and of the contract of warranty, I think the vendee was not bound to return the seed without using it; that by keeping it he has not precluded himself either from bringing an action for breach of the warranty, or from insisting on such breach in this action, in order to shew that the seed was of less value 
than the seller represented it to be."And Littledale, J., says, " I am of opinion, that where goods are warranted, the vendee is entitled, although he do not return them to the vendor or give notice of their defective quality, to bring an action for breach of the warranty; or if an action be brought against him by the vendor for the price, to prove the breach of the warranty, either in diminution of damages or in answer to the action, if the goods be of no value." [Alderson, E. If two-thirds of the seed were bad, and one-third good, the vendor would be entitled to damages for that which is good.] This is the case of a single article, that of a ship. eThis doctrine is more fully gone into in the case of Street v. May (2 B. \& Adol. 456), where it was held, that a person who had purchased a horse warranted sound might, in an action by the vendor for the price, give the breach [865] of warranty in evidence in reduction of damages. It was there said by the plaintiff's counsel in argument, that "a defence of this kind is in the nature of a cross action upon the warranty, and is admitted in order to avoid circuity of proceedings," and that view is adopted by Lord Teuterden, 0. J., in delivering the judgment of the Court:"The cases have established that the breach of warranty may be given in evidence in mitigation of damages, on the principle, as it should seem, of avoiding circuity of action." It would be quite absurd to say that it is to avoid circuity of action, if the other right of action is not extinguished. [Parke, B. This is riot the case of a warranty; it is an agreement to build a ship of a given description, and if it is not built according to the agreement, the vendee is not bound to receive it; but if he does receive the ship, is he 'not bound on a new contract on a quantum meruit, to pay for its] In Tlumitcm v. Place (1 M. \& Kob. 218), Parke, J., was of opinion, that where a tradesman furnishes work differing ifrom the specification agreed on, he is not entitled to the actual value of the work, but only to the agreed price, minus such a sum as it would take to complete the work according to the specification. [Parke, B. The rule there laid down does not apply to the present case: that action was on a quantum meruit.] The object is the civoiding circuity of action, and that must necessarily involve the extinguishment of the other right of action. The cases shew, that although the plaintiff might have sued originally for the damage sustained for the breach of contract, yet that, having given the breach in evidence in reduction of the damages claimed in the former action, he has thereby exercised the option which the law allowed him, and, as in the case of a set-off, has precluded himself from bringing this action. Allen v. Cameron (1 Or. \& M. J332) meets the objection as to the distinction between a warranty and a contract of this [866] kind. 
There A. contracted, in consideration of 2201. 10s., to sell and plant a quantity of trees on B.'s land; and also that he would, at his own costs and charges, keep in order the trees for two years after the planting, and that such as should die during that period should be replaced by him; and in an action to recover the price, it was held that evidence of non-performance by A. of any part of the contract on his part, was admissible in reduction of damages. Bayley, B., there says, in the course of the argument, "Street v. Blay goes almost the whole length of this case;" and in giving judgment he says, " Is the plaintiff liable to an abatement from the amount agreed on in respect of misconduct on his part, or non-fulfilment of what he is bound to perform? The case of Street v. Blay puts this in a plain and satisfactory point of view, not leaving the defendant to a cross action to recover for the diminution iu value by reason of the plaintiffs non-performance of the contract, but entitling him to deduct the amount of damage he has sustained thereby; that is a very plain and intelligible rule, and the present case shews the wisdom of it." That authority goes the entire length of what the present defendant is contending for. The contrary doctrine would be exceedingly unjust. If a party elects to derive a benefit by ; i plea in a former action, it estops him from bringing a cross action. The policy of the law is to compel the party to come forward with the whole of his case, and not to permit him to lie by and see his opponent's case, and then bring a cross action. In Henndl v. fairlamb (3 Esp. 104), it was held that a party cannot bring an action for what has been the object of a set-off in a former action by the defendant against him. That is the view taken of this subject in Chitty on Pleading, (vol. i. $p, 571,6$ th edition), where

1292 MONDEL V. STEEL 8 M. \&W. 867.

it is said, "These statutes were passed for the benefit of defendants, and they are not imperative; so that a defendant may waive his right to set [867] off, and bring a cross action for a debt due to him from the plaintiff; and where he is not prepared, at the time the plaintiff sues him, to prove his cross demand, it is most advisable not to plead or give notice of set oft'; for, in case he should go into evidence upon the trial in support of his cross demand, and fail in the attempt, he cannot afterwards proceed in a cross action for the amount; and a party cannot bring an action for what he has succeeded in setting oft' in a former action against him."He also cited Eastmure v. Laws (7 Scott, 461), (Huram v. More-wood (3 East, 347), and Com. Dig. Action (K. 3). 
Cleasby, in reply. There was nothing whatever in the former action to denote what amount of damage had been sustained in consequence of the breach of the contract. It is an assumption, to say that the defendant has made his election. Even if this were like the case of Street v. Bluy, the giving in evidence a breach of the agreement in reduction of damages, in the former action, would not prevent the defendant in that action from afterwards bringing an action to recover the special damage sustained by the breach of contract. Avoiding circuity of action means that the party should not be compelled to pay the whole sum specified in the agreement, and then be driven to a cross action. The distinction between the present case and those cited is, that this claim could not be pleaded as a set off, so that the plaintiff in the original action would at all events be entitled to recover nominal damages. There is no analogy between this case and a set-off, because this matter was no answer to the former action. No claim was made in respect of the breach of the contract, but the defendant merely insisted on the breach of contract as shewing that the plaintiff in that action was not entitled to recover the sum agreed upon, but only on a quantum meruit. [868] Suppose the defendant in that action had paid into Court all that the plaintiff' was entitled to recover, could not he afterwards sue for the breach of contract? A set-off is a satisfaction of the counter claim, which this was not. It does not appear that the jury have given any compensation for the special damage arising from the breach of contract. The plea, therefore, is no answer to the action.

Cur. adv. vult.

The judgment of the Court (a) was now delivered by Parke, B. In this case, the declaration is in special assumpsit on a contract to-build a ship for the plaintiff, at a certain rate per ton, and according to a certain specification : and the breach assigned is for not building a vessel with scantlings, fastenings, and planking, according to such specification; by reason whereof the ship, on a voyage from London to New South Wales and back, was so much strained that it became necessary to re fasten and repair her. 
To this declaration there was one plea, to which it is unnecessary to allude, as it was admitted to be bad on special demurrer, and is to lie amended ; and a second plea, on which the question, which we have taken time to consider, arises.

This plea states in substance, that the defendant had sued the plaintiff for the balance of the agreed price of the vessel, after payment of 3500, and also for a sum of 134 odd for extra, work, in the form of an action for work and labour, and for goods, sold and delivered ; that issue was joined, and, on the trial of the cause, the plaintiff gave evidence in his defence of the same breach of contract alleged in the declaration; and insisted, that if the amount of compensation to which he was entitled, exceeded [869] or equalled the balance of the price and the value of the extra work, the now plaintiff was entitled to a verdict; if it was less, that he was entitled to a deduction from the amount of both, of such amount of compensation. The plea proceeds to state, (and, we must assume, correctly, for the purposes of this argument, though the statement has arisen from mistake), that the learned judge before whom the cause was tried, my brother Rolfe, so directed the jury ; and that the jury found that the now defendant had committed a breach of contract, and was entitled to some compensation, which they deducted from the price of the vessel and value of the extra work; and the now defendant had judgment for the amount, after such deduction had been made, since the commencement of this suit.

The plaintiff' demurred to this plea, assigning several causes of special demurrer, which it is not necessary to notice, as we are all of opinion that it is bad in substance.

The ground on which it was endeavoured to support the plea, in a very ingenious (a) Parke, B., Alderson, B., Gurney, B., and Eolfe, B.

\section{M. \&W. 871/2. MONDEL V. STEEL 1293}

argument, was this : that a defendant in an action for the stipulated price of a chattel, which the plaintiff had contracted to make for the defendant of a particular quality, or of a specific chattel sold with a warranty, and delivered, had the option of setting: up a counter claim for breach of the contract in the one instance, or the warranty in the other, in the nature of a cross action; and that if he exercised that option, he was in the same 
situation as if he had brought such an action; and consequently, could not, after judgment in one action, bring another; and the case was likened to a set-off under the statutes. This argument was founded on no other authority than an expression of Lord Tenterden in giving the judgment of the Court in the case of Street v. Blay (2 B. \& Aid. 462), his lordship having said that a breach of warranty might be given in evidence in an action for the price of a specific [870] article sold, in mitigation of damages, " on the principle, it should seem, of avoiding cireuity of action."But we are all of opinion that no such inference is to be drawn from that expression; what was meant was, that the sum to be recovered for the price of the article might be reduced by so much as the article was diminished in value, by reason of the non-compliance with the warranty ; and that this abatement was allowed in order to save the necessity of a cross actioti. Formerly, it was the practice, where an action was brought for an agreed price of a specific chattel, sold with a warranty, or of work which was to be performed according to contract, to allow the plaintiff to recover the stipulated sum, leaving the defendant to a cross action for breach of the warranty or contract; in which action, as well the difference between the price contracted for and the real value of the articles or of the work done, as any consequential damage, might have been recovered; and this course was simple and consistent. In the one case, the performance of the warranty not being a condi;tion precedent to the payment of the price, the defendant, who received the chattel warranted, has thereby the property vested in him indefeasibly, and is incapable of returning it back ; he has all that he stipulated for as the condition of paying the price, and therefore it was held that he ought to pay it, and seek his remedy on the plaintiffs contract of warranty. In the other case, the law appears to have construed the contract as not importing that the performance of every portion of the work should be a condition precedent to the payment of the stipulated price, otherwise the least deviation would have deprived the plaintiff of the whole price; and therefore the defendant was obliged to pay it, and recover for any breach of contract on the other aide. But after the case of Sa/sten v. Butter (7 East, 479), a different practice, which had been partially [871] adopted before in the case of King v. Boston ( 7 East, 481, n.), began to prevail, and being attended with much practical convenience, has been since generally followed ; and the defendant is now permitted to shew that the chattel by reason of the noncompliance with the warranty in the one case, and the work in conjsequence of the nonperformance of the contract in the other, were diminished in value; KM v. Atkinson (2 
Camp. 64), Thornton v. Place, (1 M. \& Bob. 218), \&c. The same practice has not, however, extended to all cases of work and labour, as for instance, that of an attorney, Templar v. M'Lachlan (2 T. R. 16), unless no benefit whatever has been derived from it; nor in an action for freight; Shiels v. Davies (4 Camp. 119). It is not so easy to reconcile these deviations from the ancient practice with principle, in those particular cases above-mentioned, as it is in those where an executory contract, such as this, is made for a chattel, to be manufactured in a particular manner, or goods to be delivered according to a sample ; Gennaine v. Burton (3 Stark. 32); where the party may refuse to receive, or may return in a reasonable time, if the article is not such as bargained for ; for in these cases the acceptance or non-return affords evidence of a new contract on a quantum valebat; whereas, in a case of a delivery with a warranty of a specific chattel, there is no power of returning, and consequently no ground to imply a new contract; and in some cases of work performed, there is difficulty in finding a reason for such presumption. It must however be considered, that in all these cases of goods sold and delivered with a warranty, and work and labour, as well as the case of goods agreed to be supplied according to a contract, the rule which has been found so convenient is established ; and that it is competent for the defendant, in all of those, not to set-off, by a proceed;ing in the nature of a cross action, the amount of damages [872] which he has sus;tained by breach of the contract, but simply to defend himself by shewing how much less the subject-matter of the action was worth, by reason of the breach of contract; and to the extent that he obtains, or is capable of obtaining, an abatement of price on

\section{PRIOR V. HEM BROW 8 M. to W. 1/213.}

that account, - he must be considered as having received satisfaction for the breach of contract, and is precluded from recovering in another action to that extent; but no more.

The opinion, therefore, attributed on this record to the learned Judge is, we think, incorrect, arid not warranted by law; and all the plaintiff could by law lie allowed in diminution of damages, on the former trial, was a deduction from the agreed price, according to the difference, at the time of the delivery, between the ship us she was, and what she ought to have been according to the contract: but all claim for damages beyond that, on account of the subsequent necessity for more extensive repairs, could not have been allowed in the former aetion, and may now be recovered. 
We have already observed in the course of the argument, that the defence made in the second plea cannot be supported on the ground that it discloses a mutual agreement by the plaintiff and defendant to leave the amount of the cross claim to the jury as arbitrators, and that they have made an award. The plea does not state any such agreement, or an equivalent thereto. Our judgment must therefore be for the plaintiff.

Judgment for the plaintiff. 
Appleby v Myers

Appleby v Myers (1867) LR 2 CP 65 1;

36 LJCP 331; [1861-73] All ER Rep 452; 16 LT 669

CONTRACT, PERFORMANCE PREVENTED BY AN EVENT BEYOND THE CONTROL OF BOTH PARTIES, SUM PAYABLE ON COMPLETION, DESTRUCTION OF SUBJECT MATTER, CONTINUED EXISTENCE OF SUBJECT MATTER

\section{$\underline{\text { Facts }}$}

The plaintiffs had a contract with the defendant to erect machinery on his premises at a specific price for particular portions and to keep the premises in good repair for two years. The price for the work was to be paid at the end of the two years. After some portions of the work had been finished and others were in the course of completion, the premises with all the machinery and materials inside were destroyed by an accidental fire. The plaintiffs sued the defendant for the recovery of the sum for the completed work. The Court of Common Pleas ruled in favour of the plaintiffs. The defendant appealed to the Court of Exchequer Chamber.

\section{$\underline{\text { Issue }}$}

Are the plaintiffs entitled to recover the sum for the completed work?

\section{Held}

The appeal was allowed and the Court of Exchequer Chamber ruled in favour of the defendant.

(1) After the fire, both parties are excused from further performance of the contract.

(2) Where there is a contract to do work on one's premises and supply materials, according to which the price is to be paid upon completion of the work, the contractor is not entitled to recover anything until the whole work is completed, unless it is shown 
that the performance of the contract was prevented by the default of the person to whom the premises belong.

(3) The plaintiffs were not entitled to sue in respect of those portions of the work which had been completed, whether or not the materials used had become the property of the defendant or not.

All Answers ltd, 'Appleby V Myers' (Lawteacher.net, December 2018) <https://www.lawteacher.net/cases/appleby-v-myers.php?vref=1> accessed 20 December 2018 


\section{$\underline{\text { Sumpter v Hedges (1898) }}$}

\section{Sumpter v Hedges [1898] 1 QB 673}

The plaintiff agreed to erect upon the defendant's land two house and stables for $£ 565$. He did part of the work to the value of about $£ 333$ and then abandoned the contract. The defendant completed the buildings. The Court held that the plaintiff could not recover the value of the work done, as he had abandoned the contract.

The claimant agreed to build two houses and stables for the defendant. It was agreed that $£ 565$ would be payable on completion. The claimant commenced performance and then ran out of money and was unable to complete. He had performed just over half of the contract. The defendant completed the work himself. The claimant sought to recover $£ 333$ representing the value of the work he had completed. He argued that in completing the work himself, the defendant had thereby accepted partial performance and prevented the claimant from completing the contract.

Held:

The claimant's action failed. The court held that the defendant had no choice but to accept partial performance as he was left with a half completed house on his land.

All Answers 1td, 'Sumpter v. Hedges' (Lawteacher.net, December 2018) <https://www.lawteacher.net/cases/sumpter-v-hedges.php?vref=1> accessed 20 December 2018 


\section{Pordage v. Cole}

[K.B. 1669]

Hil. 20 \& 21 Car. II. Regis, Rol. 1607.

[Applied, Lloyd v. Lloyd, 1837, 2 My. \& Cr. 204. Referred to, Elderton v. Emmens, 1848, 6 C. B. 175. Approved, Marsden v. Moore, 1859, 4 H. \& N. 504. Explained, Hoare v. Rennie, 1859, 29 L. J. Ex. 77; 5 H. \& N. 19. Referred to, Churchward v. R. , 1865, L. R. 1 Q. B. 195. Paynter v. James, 1867-68, L. R. 2 C. P. 357; 18 L. T. 449; Button v. Thompson, 1869, L. R. 4 C. P. 343; Bradford v. Williams, 1872, L. R. 7 Ex. 261; Robinson v. Mollett, 1875, L. R. 7 H. L. 814; Bettini v. Gye, 1876, 1 Q. B. D. 187. Followed, Simpson v. Crippin, 1872, L. R. 8 Q. B. 17. Distinguished, Honck v. Muller, 1881, 7 Q. B. D. 100. Referred to, Mersey Steel \& Iron Company v. Nayler, 1884, 9 App. Cas. 443; Ebbw Vale Steel \& Iron Company v. Blaina Iron Company, 1901, 6 Com. Cas. 36.]

S. C. 1 Sid. 423. 1 Lev. 274. Sir T. Raym. 183. 2 Keb. 533, 542, 543. If it be agreed between A. and B. that B. shall pay A. a sum of money for his lands, \&c. on a particular day, these words amount to a covenant by A. to convey the lands; for agreed is the word of both; bllt it is an independent covenant, and A. may bring an action for the money before any conveyance by him of the land. ${ }^{[1]}$

Debt upon a specialty for $£ 77415$ s. The plaintiff declares that the defendant, by his certain writing of agreement made at, \&c. by the plaintiff by the name, \&c. and the defendant by the name, \&c. and brings the deed into Court, \&c., it was agreed between the plaintiff and defendant in manner and form following, (viz.) that the defendant should give to the plaintiff the sum of $£ 775$ for all his lands, with a house called Ashmole-House thereunto belonging, with the brewing vessels remaining in the said house, and with the malt-mill and wheelbarrow; and that in pursuance of the said agreement, the defendant had given to the plaintiff $5 \mathrm{~s}$. as an earnest; and it was by the 
said writing further agreed between the plaintiff and defendant, that [85 Eng Rep. 450] the defendant should pay to the plaintiff the residue of the said sum of $£ 775$ a week after the Feast of St. John the Baptist then next following (all other moveables, with the corn upon the ground, except). And although the defendant has paid five shillings, parcel, \&c. yet the said defendant, although often requested, has not paid the residue to the damage, \&c. The defendant prays oyer of the specialty, which is entered in hac verba, to wit: "11 May, 1668. It is agreed between Doctor John Pordage and Bassett Cole, Esquire, that the said Bassett Cole shall give unto the said doctor $£ 775$ for all his lands, with Ashmole-House, [1 Wms. Saunders 320] thereunto belonging, with the brewingvessels as they are now remaining in the said house, and with the malt-mill and wheelbarrow. In witness whereof we do put our hands and seals: mutually given as earnest in performance of this 5s.; the money to be paid before Midsummer, 1668; all other moveables, with the corn upon the ground, excepted. "And upon oyer thereof the defendant demurs. And Withins, of counsel with the defendant, took several exceptions to the declaration: 1 . That the demand by the declaration is of $£ 77415 \mathrm{~s}$.; whereas the whole sum is $£ 775$; and the 5s. paid for earnest shall not be taken as part of the sum of $£ 775$. Sed non allocatur; for per Curiam it shall be intended as part of the sum. 2. That the exception of the residue of the moveables is not well recited: for the word (except) in the declaration is not good for want of sense. Sed non allocatur; for it is sensible enough in the declaration: and if it were not, the declaration is good; for an insensible clause does not make the rest of the deed vitious which is sensible in itself ${ }^{[2]} 3$. The great exception was, that the plaintiff in his declaration has not averred that he had conveyed the lands, or at least tendered a conveyance of them; for the defendant has no remedy to obtain the lands, and therefore the plaintiff ought to have conveyed them, or tendered a conveyance of them, before he brought his action for the money. And it was argued by Withins, that if by one single deed two things are to be performed, namely, one by the plaintiff and the other by the defendant, if there be no mutual remedy, the plaintiff ought to aver performance of his part: Trin. 12 Jac. 1, between Holder v. Tayloe, ${ }^{[*]}$ Ughtred's case, ${ }^{[\dagger]}$ and Sir Richard Pool's case there cited, and Gray's case: ${ }^{[\#]}$ and that the word (pro) made a condition in things executory. ${ }^{[\S]}$ And here in this case it is a condition precedent which ought to be performed before the action brought; wherefore he prayed judgment for the defendant. 
But it was adjudged by the Court, that the action was well brought without an averment of the conveyance of the land; because it shall be intended that both parties have sealed the specialty. And if the plaintiff has not conveyed the land to the defendant, he has also an action of covenant against the plaintiff upon the agreement contained in the deed, which amounts to a covenant on the part of the plaintiff to convey the land; and so each party has mutual remedy against the other. But it might be otherwise if the specialty had been the words of the defendant only, and not the words of both parties by way of agreement as it is here. And by the conclusion of the deed it is said, that both parties had sealed ${ }^{[3]} i t$; and therefore judgment was given for the plaintiff, ${ }^{[4]}$ which was afterwards affirmed in the Exchequer-Chamber, Trin. 22 of King Charles the Second.

[1] S. C. cited and recognised, 1 Salk. 171. 1 Lutw. 251. 12 Mod. 461, 462. 1 Ld. Raym. 665. 8 Mod. 42. 1 Salk. 113. 2 H. Black. 393. For perhaps the conveyance cannot be made by the day appointed for payment of the money. Sir T. Raym, 183.

[2] S. P. Vaug. 176, Crowle v. Swindles. 1 Lutw. 493, 496, Hilton v. Smith.

[*] 1 Rol. Abr. 518 (C), pl. 2, 3.

† 7 Rep. 10 .

[†1 5 Rep. 78, 79. S. C. Cro. Eliz. 405.

[§] Co. Litt. 204 a.

[3] It appears indeed from the profert, that the defendant had sealed the agreement; but if it were at all material towards the support of this case, that both parties should have sealed the agreement, they do not appear to have done so here. It does not follow because the words "in witness whereof we do put our hands and seals" are used in the conclusion of the agreement, that therefore it was sealed by them. On the contrary, it has been decided, that these words do not amount to an averment that the parties sealed the instrument: see ante, 291, Cabell v. Vaughan, and note (1).

[4] Almost all the old cases, and many of the modern ones all this subject, are decided upon distinctions so nice and technical, that it is very difficult, if not impracticable, to deduce from them any certain rule or principle by which it can be ascertained, what covenants are independent, and what dependent; and of course, when [85 Eng Rep. 451] it is necessary to aver performance in the declaration, and when not. Thus, if A. covenant with B. to serve him for a year, and B. covenant with A. to pay him $£ 10$, it is held that these are independent covenants, and A. may maintain an action against B. for 
the money before any service; but if B. had covenanted to pay him $£ 10$ for the service, these words make the service a condition precedent, and A. cannot enforce payment of the money until he has performed the service. So where A. covenants with B. to marry his daughter, and B. covenants to convey an estate to A. and the daughter in special tail, it is said that though A. marry another woman, or the daughter another man, still A. may have an action against $\mathrm{B}$. on the covenant; but if $\mathrm{B}$. had covenanted to convey the estate for the cause aforesaid, the marriage is a condition precedent, and no action will lie until it be solemnised. 15 H. 7, 10, pl. 17. Bro. Covenant, 22. 12 Mod. 460, Thorpe v. Thorpe. Hob. 106, Lampleigh v. Brathwait. Also where A., in consideration of $£ 10$, promised to deliver to B. all the books of the law, it has been said, that B. may bring an action against $\mathrm{A}$. for the books before any payment; but if A., in consideration that B. will pay him $£ 10$, will deliver to him all the books of the law, B. cannot bring an action for the books before he has paid the money. 1 Rol. Rep. 125, Everard v. Hopkins, per Coke C.J. So where B. covenanted with C. his copyholder, to assure to him and his heirs the freehold and inheritance of his copyhold, and C., in consideration of the same performed, covenanted to pay such a sum, it was adjudged that this was a condition precedent, and B. must make the assurance before he is entitled to the money; but if the words had been, in consideration of the said covenant to be performed, B. might bring an action for the money before he made the assurance. 3 Leon. 219, Brocas's case. And lastly, where articles of agreement were made between A. and B. and a covenant by A., that, for the consideration thereafter expressed, he should convey certain lands to B. in fee, and B., on his part, for the consideration aforesaid, covenanted to pay a sum of money to A.; it was held, that these were independent covenants, and A. might bring an action for the money before any conveyance of the lands. 1 Rol. Abr. 415, pl. 8, S. C. cited 12 Mod. 463, Thorpe v. Thorpe. 1 Ld. Raym. 665, 666. 1 Lutw. 251, 252. There are many other authorities of a similar nature which I refer the reader to. 1 Rol. Rep. 336, Spanish Ambassador v. Gifford. Yelv. 133, 134, Bettisworth v. Campion. Hob. 88, Nichols v. Raynbred. 1 Lev. 293, Beany v. Turner. Hard. 102, 103, Gibbons v. Prewd. 1 Str. 535, Blackwell v. Nash. Ibid. 712, Dawson v. Myer. 1 Wils. 88, Martindale v. Fisher. Hence it appears that the Judges in these cases seem to have founded their construction of the independency or dependency of covenants or agreements on artificial and subtle distinctions, without regarding the intent and meaning of the parties. For the rule which is contained in them all seems clear and indisputable; that where 
there are several covenants, promises, or agreements, which are independent of each other, one party may bring an action against the other for a breach of his covenants, \&c. without averring a performance of the covenants, \&c. on his, the plaintiff's part; and it is no excuse for the defendant to allege in his plea a breach of the covenants, \&c. on the part of the plaintiff; according to Justinian's rule in the civil law, "Qui actionem habet ad rem recuperandum, ipsam rem habere videtur." Justin. de Regulis Juris, 361. But where the covenants, \&c. are dependent, it is necessary for the plaintiff to aver and prove a performance of the covenants, \&c. on his part, to entitle himself to an action for the breach of the covenants on the part of the defendant; and so are also 7 Rep. 10 a. b. Ughtred's case. Doug. 690, 3d ed. Kingston v. Preston, cited in Jones v. Barkley. The difficulty lies in the application of this rule to the particular case. It is justly observed, that covenants, \&c. are to be construed to be either dependent or independent of each other, according to the intention and meaning of the parties, and the good sense of the case; and technical words should give way to such intention. 1 T. R. 645, Hotham v. East India Company. 6 T. R. 668, Porter v. Shephard. Ibid. 571, Campbell v. Jones. 7 T. R. 130, Morton v. Lamb. In order therefore to discover that intention, and thereby to learn, with some degree of certainty, when performance is necessary to be averred in the declaration, and when not, it may not be improper to lay down a few rules, which will perhaps be found useful for that purpose.

1. If a day be appointed for payment of money, or part of it, or for doing any other act, and the day is to happen, or may happen, before the thing which is the con [85 Eng Rep. 452] sideration of the money, or other act, is to be performed, an action may be brought for the money, or for not doing such other act before performance; for it appears that the party relied upon his remedy, and did not intend to make the performance a condition precedent: and so it is where no time is fixed for performance of that, which is the consideration of the money or other act. Dyer, 76 a. in margine. 1 Salk. 171, Thorpe v. Thorpe. S. C. 1 Ld. Raym. 665. 1 Lutw. 250. 12 Mod. 461. 1 Vent. 177, Peter v. Opie, per Hale C.J. 2 Saund. 350, S. C. 1 Salk. 113, Callonel v. Briggs. 2 H. Black. 389, Terry v. Duntze. 6 T. R. 572, Campbell v. Jones. ${ }^{\text {[a] }}$ This seems to be the ground of the judgment in this case of Pordage v. Cole, the money being appointed to be paid on a fixed day, which might happen before the lands were, or could be, conveyed. And upon the same ground is 48 Edw. 3, 2, 3, decided. Lord Holt, in Thorpe v. Thorpe, 12 Mod. 461. 1 Lutw. 250, 251, observes, that the report of 48 Edw. 3, in 7 Rep. 10 b. Ughtred's 
case, is incorrect. It is thus put in that book. Sir Richard Pool covenants with Sir Ralph Tolcelser to serve him with three esquires in the wars of France; Sir Ralph Tolcelser covenants, in consideration of those services, to pay him so much money; and it is said, that an action will lie for the money before any service. But in the book at large the case will be found to have been adjudged upon the above-mentioned rule. The report is thisSir Richard Pool covenants with Sir Ralph Tolcelser to serve him with three esquires in the wars of France; and Sir Ralph covenants with him to pay so much money for the service; and it was further agreed that half the money should be paid in England on a certain day before they went for France; and the rest by quarterly payments (which also might incur before the service): and it was held that an action might be brought for the money before the service.

But, 2. When a day is appointed for the payment of money, \&c. and the day is to happen after the thing which is the consideration of the money, \&c. is to be performed, no action can be maintained for the money, \&c. before performance. 1 Salk. 171, Thorpe v. Thorpe, 2d Resolution. 12 Mod. 462. 1 Ld. Raym. 665. 1 Lutw. 251. Dyer, 76 a. pl. 30. ${ }^{\text {b] }}$

3. Where a covenant goes only to part of the consideration on both sides, and a breach of such covenant may be paid for in damages, it is an independent covenant, and an action may be maintained for a breach of the covenant all the part of the defendant, without averring performance in the declaration. As where A. by deed conveyed to B. the equity of redemption of a plantation in the West Indies, together with the stock of negroes upon it, in consideration of $£ 500$. and an annuity of $£ 160$ for life, and covenanted that he had a good title to the plantation, was lawfully possessed of the negroes, and B. should quietly enjoy: and B. covenanted that, A. well and truly performing all and every thing therein contained on his part to be performed, he would pay the annuity: in an action by A. against B. on this covenant, the breach assigned was, the lion-payment of the annuity: plea, that A. was not at the time legally possessed of the negroes on the plantation, and so had not a good title to convey. The Court of K. B. on demurrer held the plea to be ill, and [85 Eng Rep. 453] added, that if such plea were allowed, anyone negro, not being the property of A., would bar the action. E. T. 17 Geo. 3, K. B. Boon v. Eyre. 1 H. Black. 273, note (a). 2 Black. Rep. 1312, S. C. The whole consideration of the covenant on the part of B. the purchaser to pay the money, was the conveyance by A. the seller to him of the equity of redemption of the plantation, and 
also the stock of negroes upon it. The excuse for non-payment of the money was, that A. had broke his covenant as to part of the consideration, namely, the stock of negroes. But as it appeared that A. had conveyed the equity of redemption to B., and so had in part executed his covenant, it would be unreasonable that B. should keep the plantation, and yet refuse payment, because A. had not a good title to the negroes. 6 T. R. 573, per Ashhurst J. Besides, the damages sustained by the parties would be unequal, if A.'s covenant were held to be a condition precedent. 1 H. Black. 279, Duke of St. Alban's v. Shore. For A. on the one side would lose the consideration money of the sale, but B.'s damage on the other might consist perhaps in the loss only of a few negroes. So where it was agreed between C. and D. that, in consideration of $£ 500, C$. should teach D. the art of bleaching materials for making paper, and permit him, during the continuance of a patent which C. had obtained for that purpose, to bleach such materials according to the specification; and C., in consideration of the sum of $£ 250$ paid. and of the further sum of $£ 250$ to be paid by $\mathrm{D}$. to him, covenanted that he would with all possible expedition teach D. the method of bleaching such materials, and D. covenanted that he would, on or before the 24th of February 1794, or sooner, in case C. should before that time have taught him the bleaching of such materials, pay to $C$. the further sum of $£ 250$; in covenant by $C$. against $D$. the breach assigned was the non-payment of the $£ 250$. Demurrer, that it was not averred that C. had taught D. the method of bleaching such materials. But it was held by the Court, that the whole consideration of the agreement being, that C. should permit D. to bleach materials as well as teach him the method of doing it, the covenant by $\mathrm{C}$. to teach formed but part of the consideration, for a breach of which D. might recover a recompence in damages. And C. having in part executed his agreement by transferring to D. a right to exercise the patent, he ought not to keep that right without paying the remainder of the consideration, because he may have sustained some damage by D.'s not having instructed him; and the demurrer was overruled. 6 T. R. 570, Campbell v. Jones. ${ }^{[\mathrm{c}]}$ Hence it appears that the reason of the decision in these and other similar cases, besides the inequality of the damages, seems to be, that where a person has received a part of the consideration for which he entered into the agreement, it would be unjust that because he has not had the whole, he should therefore be permitted to enjoy that part without either paying or doing any thing for it. Therefore the law obliges him to perform the agreement on his part; and leaves him to his remedy to recover any damage he may have sustained in not having received the 
whole consideration. And hence, too, it seems it must appear upon the record [85 Eng Rep. 454] that the consideration was executed in part: as in Boon v. Eyre, abovementioned, the action was on a deed, whereby the plaintiff had conveyed to the defendant the equity of redemption of the plantation; for the defendant did not deny the plaintiff's title to convey it: so in Campbellv. Jones, the plaintiff had transferred to the defendant a right to exercise the patent. Therefore, if an action be brought on a covenant or agreement contained in articles of agreement or other executory contract where the whole is future, it seems necessary to aver performance in the declaration of the whole, or at least of part of that which the plaintiff has covenanted to do; or at least it must be admitted by the plea that he has performed part. As where A., by articles of agreement, in consideration of a sum of money to be paid to him by B. on a certain day, covenants to convey to B. on the same day a house together with the fixtures and furniture therein, and that he was lawfully seised of the house, and possessed of the fixtures and furniture; in an action against B. for the money, A. must aver that he conveyed either the whole of the premises, or at least the house, to B., or it must be admitted by B. in his plea that A. did convey the house, but was not lawfully possessed of the furniture or fixtures. ${ }^{\text {[d] }}$

4. But where the mutual covenants go to the whole consideration on both sides, they are mutual conditions, and performance must be averred. 1 Vent. 147, Large v. Cheshire. 1 H. Black. 270, Duke of St. Alban's v. Shore.

5. Where two acts are to be done at the same time, as where A. covenants to convey an estate to B. on such a day, and in consideration thereof B. covenants to pay A. a sum of money on the same day, neither can maintain an action without shewing performance of, or an offer to perform, his part, though it is not certain which of them is obliged to do the first act: and this particularly applies to all cases of sale. 1 Salk 112, 113, Callonel v. Briggs. Ibid. 171, Thorpe v. Thorpe. 2 Salk. 623, Lancashire v. Killingworth. Doug. 691, 3d ed., Kingston v. Preston. Ibid. 684. Jones v. Barkley. 4 T. R. 761, Goodisson v. Nunn. 6 T. R. 665, Porter v. Shephard. 7 T. R. 125, Morton v. Lamb. 8 T. R. 366, Glazebrook v. Woodrow. 2 Saund. 352, Peeters v. Opie, note (5). 2 H. Black. 178, French v. Campbell. Ibid. 123, Phillips v. Fielding. 2 Saund. 106, Holdipp v. Otway. 1 East, 203, Rawson v. Johnson. Ibid. 619, Heard v. Wadham.4 East, 477, Hall v. Cazenove. 6 East, 555, Martin v. Smith. ${ }^{\text {[e] }}$ 
[a] [1 B. \& Ad. 124, Ikin v. Brook. 4 C. \& P. 309, Irving v. King. 10 A. \& E. 50, Mattock v. Kinglake. 2 P. \& D. 343, S. C. 10 A. \& E. 793, Lord Howden v. Simpson. 2 P. \& D. 714, S. C. 9 M. \& W. 315, Pistor v. Cater. 10 M. \& W. 355, Wilks v. Smith.See also 1 Bing. N. C. 671, 677, Alexander v. Gardner. 1 Scott, 630, S. C.]

[b] Therefore, where a ship was let to freight at a certain sum per month, to be paid on her final discharge at the end of the voyage, and she was lost in the middle of the voyage, it was held that no action could be maintained for any freight. Byrne v. Pattinson, Abbot on Shipping, 347. 8 East, 473, Smith v. Wilson. [2 Bing N. C. 555, Mitchell v. Darthez. 2 Scott, 771, S. C.] So where freight was to be paid on the ship's arrival at her first destined port, and she was lost before her arrival. 2 B. \& A. 17, Gibbon v. Mendez. But where a day is specified for the performance of certain works, and money is to be paid' on performance, although the works be not performed on the day specified, yet an action may be maintained for the money when they are performed, and the party who is to pay the money must have recourse to a cross action for any damages occasioned by the delay. Cock v. Curtoys, K. B. M. T. 2 Geo. 4, M. S. [3 Bing. N. C. 737, Lucas v. Godwin. 4 Scott, 502, S. C.]

[c] See 10 East, 295, Ritchie v. Atkinson, which was decided upon the same grounds. Also 10 East, 555, Harelockv. Geddes. 12 East, 389, Davidson v. Gwynne. 3 M. \&. S. 308, Storer v. Gordon. 8 Taunt. 576, Fothergill v. Walton. 2 B. Moore, 630, S. C. [4 Doug. 356, Ohlsen v. Drummond. 4 Bing. 409, Carpenter v. Cresswell. 1 Moo. \& P. 66, S. C. 2 B. \& Ad. 822, 829, 831, Rose v. Poulton. 4 A. \& E. 599, Franklin v. Miller. 3 Bing. N. C. 355, Stavers v. Curling. 3 Scott, 740, S. C. 3 Bing. N. C. 737, Lucas v. Godwin. 4 Scott, 502, S. C. 2 M. \& Cr. 192, Lloyd v. Loyd 4 Bing. N. C. 105, Dallman v. King. 5 Scott, 382, S. C. 4 M. \& W. 734, 747, Corrall v. Cattell. 1 Mann. \& Gr. 841, 851, Clark v. Morrell. 2 Scott, 17, S. C. But see also 5 B. \& C. 269, Whitcher v. Hall. Post, Vol. II. 352, et seq. notes to Peeters v. Opie. Where the consideration for the payment of money is entire and indivisible, as where the benefit expected by the defendant under the agreement is to result from the enjoyment of every part of the consideration jointly, so that the money payable is neither apportioned by the contract, nor capable of being apportioned by a jury, no action is maintainable, if any part of the consideration has failed; for, being entire, by failing partially, it fails altogether. 4 M. \& 
W. 295, Chanter v. Leese. 5 M. \& W. 698, S. C. in Cam. Scacc. Where the plaintiff has been guilty of a breach of contract on his part, which goes only to part of the consideration, the defendant may give evidence of such breach in mitigation of damages. 1 Cr. \& M. 832, Allen v. Cameron. 3 Tyrw. 907, S. C.]

[d] [4 M. \& W. 295, Chanter v. Leese. 5 M. \& W. 698, S. C. in Cam. Scacc.]

[e] 7 T. R. 381, Cook v. Jennings. 8 Taunt. 62, Ferry v. Williams. 1 B. Moore, 498, S. C. [See post, Vol. II. 352, et seq. note (3) to Peeters v. Opie.]

Available at H2O Case Admin., accessed 20 December 2018. 


\section{Plotnick v. Pennsylvania Smelting \& Refining Co}

Plotnick v. Pennsylvania Smelting \& Refining Co, 194 F.2d 859 (3d Cir. 1952)

Citation. 22 Ill.194 F.2d 859 (3d Cir. 1952)

Brief Fact Summary. Plaintiff and Defendant had an installment contract where Plaintiff bought lead from Defendant. Plaintiff's payment for an order of lead was late. Defendant refused to send the order.

Synopsis of Rule of Law. In an installment contract, on must perform even if the other party is late in performance unless, it would cause unreasonable hardship to perform or one reasonably believes the other party will not perform.

Facts. Plaintiff, a Pennsylvania buyer, had a contract with Defendant, a Canadian seller to buy lead. Throughout their dealings with each other both complained, rightly, that the other was slow to perform. Plaintiff and Defendant made a contract for 200 tons of lead to be delivered to Plaintiff no later than Dec 25. They agreed that at least 63 percent of the price per carload would be paid shortly after each shipment, with the balance to be paid within four weeks after delivery. The shipment began, although the second and third ones were after Dec 25. Plaintiff paid for the first and second shipments in a more or less timely fashion. The third shipment, which arrived on March 23, was not paid for. On April 7, Plaintiff said he needed more lead or he would have to buy it on the open market. Defendant replied that unless the previous installment was paid for, he would not send any more lead. On June 2, Defendant notified Plaintiff that the Canadian Government had imposed export controls on lead. Plaintiff complained during that time, that he was selling lead faster than he could get it in and that he was withholding payment on the third shipment because Defendant refused to send the fourth.

Issue. Was Defendant justified in withholding delivery of the forth shipment because Plaintiff had not paid for the third?

Available at Casebriefs.com Web site, owned and operated by Casebriefs LLC. 